CAMILA DE BARROS GALLO

Estudo de polimorfismos de nucleotídeo único em genes de receptores Toll-like em pacientes com líquen plano oral e pacientes com carcinoma epidermóide de boca 
CAMILA DE BARROS GALLO

Estudo de polimorfismos de nucleotídeo único em genes de receptores Toll-like em pacientes com líquen plano oral e pacientes com carcinoma epidermóide de boca

Versão corrigida

Tese apresentada à Faculdade de Odontologia da Universidade de São Paulo, para obter o título de Doutor pelo Programa de Pós-Graduação em Odontologia.

Área de Concentração: Diagnóstico Bucal

Orientador: Prof. Dr. Norberto Nobuo Sugaya

São Paulo

2012 
Autorizo a reprodução e divulgação total ou parcial deste trabalho, por qualquer meio convencional ou eletrônico, para fins de estudo e pesquisa, desde que citada a fonte.

Catalogação da Publicação

Serviço de Documentação Odontológica

Faculdade de Odontologia da Universidade de São Paulo

Gallo, Camila de Barros.

Estudo de polimorfismos de nucleotídeo único em genes de receptores Toll-like em pacientes com líquen plano oral e pacientes com carcinoma epidermóide de boca / Camila de Barros Gallo ; orientador Norberto Nobuo Sugaya. -- São Paulo, 2012.

96 p. : fig., tab., graf. ; $30 \mathrm{~cm}$.

Tese (Doutorado) -- Programa de Pós-Graduação em Odontologia. Área de Concentração: Diagnóstico Bucal. -- Faculdade de Odontologia da Universidade de São Paulo.

Versão corrigida.

1. Líquen plano bucal. 2. Carcinoma de células escamosas. 3. Polimorfismo. 4. Genes. 5. Patologia bucal. I. Sugaya, Norberto Nobuo. II. Título. 
Gallo CB. Estudo de polimorfismos de nucleotídeo único em genes de receptores Toll-like em pacientes com líquen plano oral e pacientes com carcinoma epidermóide de boca. Tese apresentada à Faculdade de Odontologia da Universidade de São Paulo para obtenção do título de Doutor em Odontologia.

Aprovado em: $/ 2012$

\section{Banca Examinadora}

$\operatorname{Prof}(\mathrm{a}) . \operatorname{Dr}(\mathrm{a})$. Instituição:

Julgamento: Assinatura:

$\operatorname{Prof}(\mathrm{a}) \cdot \operatorname{Dr}(\mathrm{a})$ Instituição:

Julgamento: Assinatura:

$\operatorname{Prof}(\mathrm{a}) . \operatorname{Dr}(\mathrm{a})$. Instituição:

Julgamento: Assinatura:

Prof(a). Dr(a). Instituição:

Julgamento: Assinatura:

Prof(a). Dr(a). Instituição:

Julgamento: Assinatura: 


\section{DEDICATÓRIA}

Aos mens pais, Carlos e María da Consolação, por tudo que fizeram e fazem por mim em todos os dias de minha vida, pois não bastou ser pai e mãe.

"A vocês, que me deram a vida e me ensinaram a vivê-la com dignidade, não bastaria um obrigado. A vocês, que ituminaram os caminhos obscuros com afeto e dedicação para que os trithasse sem medo e cheios de esperanças, não bastaria um muito obrigado. A vocês, que se doaram inteiros e renunciaram aos seus sonhos, para que, muitas vezes, pudesse reatizar os mens. Pela longa espera e compreensão durante minhas longas viagens, não bastaria um muitissimo obrigado. A vocês, pais por natureza, por opçã o amor, não bastaria dizer, que não tenho palavras para agradecer tudo isso. Mas é o que me acontece agora, quando procuro arduamente uma forma verbal de exprimir uma emoção ímpar. Uma emoção que jamais sería traduzida por palauras. Amo vocês!" (Desconhecido)

Aos mens irmãos-amigos, Luciana e Alexandre, e aos meus amigos-irmãos, Alessandra, Ana Carola, Beatriz, Carina, Fabiana, Renata, Maricarmen, Marilu, e Natalia muito obrigada por fazerem parte de mais esta históría e muito obrigada a aqueles que entraram nesta história!

"A amizade duplica as alegrias e divide as tristezas."

Francis Bacon

Ao mew orientador Norberto, pela sua amizade e paciêncía infinita, por continuar depositando grande confiança em mim, sempre apoiada em

lindissimas palavras das quais me sinto imensamente orguthosa.

E ao mew novo orientador, Aguirre, pela hospitalidade e constante encorajamento e estimulo!

"Feliz aquele que transfere o que sabe e aprende o que ensina." cora Coratina

E a Deus...

"Deus está nas coincidências."

Nelson Rodrigues 


\section{AGRADECIMENTOS}

Ao meu orientador no Brasil, Prof. Dr. Norberto Nobuo Sugaya, pelos ensinamentos, amizade e confiança continuamente renovada.

Ao meu orientador no exterior, Prof. Dr. Jose Manuel Aguirre Urizar, pela oportunidade, hospitalidade, ensinamentos e estímulo.

Ao Prof. Dr. Fábio Daumas Nunes da Disciplina de Patologia Bucal da Faculdade de Odontologia da Universidade de São Paulo, pela possibilidade de desenvolver futuramente a continuação desta pesquisa no Laboratório de Patologia Molecular, com a colaboração de sua equipe.

Aos demais Professores da Disciplina de Estomatologia Clínica e Patologia Bucal da Faculdade de Odontologia da Universidade de São Paulo (FOUSP) e Professores da Unidade de Medicina Oral e Patologia Oral e Maxilofacial da Faculdade de Medicina e Odontologia da Universidade do País Basco (UPV/EHU) pela amizade e convivência compartilhada.

Aos alunos e ex-alunos da pós-graduação e da iniciação científica das Disciplinas de Estomatologia Clínica e Patologia Bucal: Alessandra Camargo, Ana Paula Candido, Anna Torrezani, Bianca Fréo, Carla Siqueira, Érica Patrício, Gustavo Rabelo, Ingrid Schneider, Lígia Gonzaga, Maria Angela Mimura, Vivian Pellegrini. Muito obrigada pelo carinho, amizade e os momentos agradáveis de convivência no dia-a-dia da clínica, nos momentos de "jacarezar", nos encontros do "réchaud" e nas incríveis e inesquecíveis viagens a congressos! O que era difícil ficou leve e coleciono muitos momentos felizes e divertidos! 
Aos alunos do Master de Patologia Oral e da pós-graduação e pós-doutorado do Departamento de Estomatologia da UPV/EHU: Amelia Acha, Alvaro Peñaranda, Begoña Martinez, Maria del Carmen Gonzáles, Maria Luisa Gainza, María Prieto, Natalia Rey, Xabier Marichalar, Zummaly Zorilla. Também Ihes agradeço a amizade e os momentos inesquecíveis que passamos juntos, afinal nesta minha temporada fora aconteceu de tudo: de sol e praia a neve e esquis; de festinhas no apartamento com diversas experiências gastronômicas a incêndios no edifício; de fotos para a revista da universidade e entrevista pelos alunos de jornalismo a réveillon e carnaval com roupas de inverno; de lágrimas a sorrisos e gargalhadas! Foi intenso, foi completo, sinto saudades imensas!

Às secretárias e técnicos do Departamento de Estomatologia da FOUSP, especialmente Nina, Cecília e Cida; pela agradável convivência e colaboração.

Às funcionárias do setor de pós-graduação da FOUSP, Cátia e Alessandra, e à bibliotecária da FOUSP, Glauci, por todo apoio, presteza e agilidade nas resoluções das minhas inúmeras dúvidas.

À Coordenação de Aperfeiçoamento de Pessoal de Nível Superior (CAPES) pela bolsa concedida no país (demanda social) e pela bolsa concedida no exterior, por meio do Programa de Doutorado com Estágio no Exterior (PDEE - doutoradosanduíche). 
"Eutentei evitar

Liguei a TV e deitei no sofá Desde que haja tempo pra sonhar

E assuntos pra desenvolver

Nãoé muito fácil destigar

Me dá pena do meu chinês

Por ele eu passava o dia inteiro

A meditar

Bebendo chá verde ele me diz

"Fica feliz que vai funcionar"

Mas eutôfeliz,

Eu juro peto mew irmão

O saldo final de tudo

Foi mais positivo que mil divãs

Por isso que não adianta

Querer julgar

É cada um por si

Na sua

Própria botha de ar

Mas o que ew penso mesmo

É encontrar alguém que me dê carinho e beujo

Me trate como um neném,

Me trate muito bem

Ah, eusó quero amor

Seja como for o amor

Sejabom, sejabom,

Seja bom, seja amor

Me faz mais feliz

Me dá asas prafluir

E cantar o amor

Laiá, laiá, laiá"

Chá Verde - Tiêe,

que embatow meus sonhos

muitas noites em Bilbao!

"Todas as mudanças, mesmo as mais esperadas, tem um quê de melancolia, sempre deixam uma parte de nós para trás; Nós devemos morrer em uma vida antes de poder entrar em outra." 


\section{RESUMO}

Gallo CB. Estudo de polimorfismos de nucleotídeo único em genes de receptores Toll-like em pacientes com líquen plano oral e pacientes com carcinoma epidermóide de boca [tese]. São Paulo: Universidade de São Paulo, Faculdade de Odontologia; 2012. Versão Original.

Polimorfismos em genes de receptores Toll-like (TLR) podem modular o risco de desenvolvimento de infecção, inflamação crônica e câncer. $O$ objetivo deste estudo foi investigar a associação de polimorfismos em TLR ao risco aumentado de desenvolvimento de câncer de cabeça e pescoço, o carcinoma epidermóide (CEC) de boca e de laringe, e lesões bucais com potencial de transformação maligna, como o líquen plano oral (LPO), incluindo lesões idiopáticas e lesões liquenóides (LLO). Para tal foi conduzido um estudo caso-controle com 40 pacientes com CEC de boca, 35 com CEC de laringe, 175 com LPO (129 idiopático e 46 LLO) e 89 controles saudáveis, todos de origem basca. Oito SNP nos TLR1, TLR2, TLR4, TLR6, TLR9 e TLR10 foram genotipados por ensaios TaqMan ${ }^{\circledR}$ ou pirosequenciamento. A análise estatística por meio do teste qui-quadrado mostrou que a variante A, para o SNP TLR2-rs4696480 aumentou significativamente o risco para o desenvolvimento de CEC de boca $(p=0.03)$ e LLO $(p=0.0223)$. O genótipo AT representa risco de desenvolvimento de CEC de boca aumentado em 5.3 vezes quando comparado ao genótipo TT (OR=5.3, IC95\%=1.19-13.63), e genótipo AA em 6.6 vezes (OR=6.6, IC95\%=1.30-33.89). Quanto ao desenvolvimento de LLO, o genótipo AT representa um aumento no risco de 4.6 vezes comparado ao genótipo TT (OR=4.6, IC95\%=1.55-13.38) e o genótipo AA em 4.1 vezes (OR=4.1, IC95\%=1.33-12.88). Embora os genótipos AT e AA ocorram com significativa frequência no grupo LPO idiopático $(p=0.045)$, este SNP não foi correlacionado estatisticamente à susceptibilidade de desenvolvimento deste. O SNP TLR2-rs4696480 pode ser relevante para o risco de desenvolvimento de CEC de boca e LLO nesta população, incentivando novos estudos sobre a possível associação destes grupos de doenças e SNP no gene do TLR2, colaborando com a demonstração de polimorfismos de TLR como marcadores úteis do prognóstico e prevenção do câncer de boca.

Palavras-chave: receptores Toll-like, líquen plano oral, carcinoma epidermóide de boca, polimorfismos de nucleotídeo único. 


\begin{abstract}
Gallo CB. Toll-like receptor single nucleotide polymorphisms in patients with oral lichen planus and oral squamous cell carcinoma [thesis]. São Paulo: Universidade de São Paulo, Faculdade de Odontologia; 2012. Versão Original.

Polymorphisms in toll-like receptor (TLR) genes may modulate the risk of infection, chronic inflammation and cancer. This study investigated whether TLR polymorphisms were associated with an increased risk of head and neck cancer, including oral (OSCC) and laryngeal squamous cell carcinoma (LSCC); and oral premalignant disorders such as oral lichenoid disease (OLD), including oral lichen planus (OLP) and oral lichenoid lesions (OLL). This case-control study included 40 OSCC, 35 LSCC, 175 OLD (129 OLP and 46 OLL) patients and 89 healthy controls, all of them from the Basque Country. Genetic polymorphisms in TLR1, TLR2, TLR4, TLR6, TLR9, and TLR10 were genotyped by TaqMan® assays or pyrosequencing. Chi-square analysis showed that the variant A for the SNP TLR2-rs4696480 increased OSCC $(p=0.03)$ and OLL $(p=0.0223)$ risk significantly. AT genotype increases the risk of developing an OSCC by 5.3 times compared with TT genotype $(\mathrm{OR}=5.3,95 \% \mathrm{Cl}=1.19-13.63)$, and the $\mathrm{AA}$ by 6.6 times $(\mathrm{OR}=6.6,95 \% \mathrm{Cl}=1.30$ 33.89). AT genotype increases the risk of developing OLL by 4.6 times compared with TT genotype $(\mathrm{OR}=4.6,95 \% \mathrm{Cl}=1.55-13.38)$ and the $\mathrm{AA}$ by 4.1 times $(\mathrm{OR}=4.1$, $95 \% \mathrm{Cl}=1.33-12.88)$. Although these mutated genotypes were significantly frequent in the OLP group ( $p=0.045)$, this SNP was not correlated with OLP susceptibility. TLR2rs4696480 polymorphism may be relevant to OSCC and OLL susceptibility in this population; encouraging further studies to assess the possible association of this group of potentially malignant disorders and oral cancer with TLR2 SNP, which may help to demonstrate that TLR polymorphisms may be useful markers to prognosis and cancer prevention.
\end{abstract}

Keywords: Toll-like receptors, oral lichen planus, oral squamous cell carcinoma, single nucleotide polymorphisms. 


\section{LISTA DE ILUSTRAÇÕES}

Figura 2.1 - Diagrama das vias de sinalização dos TLR. Estes receptores localizam-se em diferentes compartimentos nas células humanas de acordo com os ligantes correspondentes. Os TLR2, TLR4, TLR6, TLR5, TLR10 estão localizados na membrana plasmática, enquanto os TLR3, TLR7, TLR8 e TLR9 estão localizados nos endossomos. O TLR2 forma heterodímero com os TLR1, TLR6 e TLR10. CD14 e MD-2 são proteínas acessórias necessárias para que o TLR4 execute suas funções. Após o reconhecimento de seus seus respectivos ligantes, os TLR recrutam moléculas adaptadoras a sua porção intracelular, como MyD88 (exceto TLR3) e TRIF (TLR3 e TLR4), para ativar IRAK4, TRAF6 e IKK. A sequencia da ativação destas moléculas ativa por sua vez a via de sinalização do NK-kB, MAPK e IRF, que induz a transcrição do DNA para produção de uma série de respostas celulares específicas relacionadas com a proliferação celular, sobrevivência e inflamação, com a produção de citocinas pró-inflamatórias e interferon do tipo I (no caso das respostas antivirais). MyD88: fator de diferenciação mielóide 88; TIRAP: proteína adaptadora contendo domínio intracelular TIR; TRAM: molécula adaptadora relacionada ao TRIF; TRIF: adaptador contendo o domínio TIR indutor de interferon- $\beta$; IRAK:quinase associada ao receptor de IL-1; TRAF: fator associado ao receptor de TNF; IKK: inibidor kappa quinase; TBK TAK: quinase ativada pelo TGF; TAB: proteína de ligação a TAK; IRF: fator regulador do interferon; MIKK (MAPK): proteína quinase ativada por mitógeno p38 e JNK; JNK: quinase c-Jun N-terminal; NFkB: factor nuclear kappa B

Figura 2.2 - Esquematização dos critérios de diagnóstico do LPO estabelecidos pela Organização Mundial da Saúde e modificados por Van der Meij e Van der Waal (2003) em relação às características clínicas e histológicas.............................................................................25

Figura 4.1 - Ilustração do ensaio Taqman $\AA^{\circledR}$ para genotipagem. À esquerda observa-se que estes ensaios utilizam, além dos dois iniciadores (forward primer e reverse primer), sondas específicas para cada um dos alelos marcadas com diferentes agentes flouróforos (VIC® e FAM®), que permitem a identificação dos alelos de forma precisa. À direita observamse os resultados de genotipagem de um ensaio representados graficamente, sendo que cada ponto representa uma amostra. A cor e posição no gráfico indica o genótipo de cada amostra: azul - homozigotos para o alelo 1 (geralmente os marcados por FAM®, verde - heterozigóticos (marcados pelos dois fluoróforos) e vermelha - homozigotos para o alelo 2 (geralmente marcado por VIC®) e os pontos restantes representam os controlos negativos e as amostras que não foram adequadamente amplificadas.

Figura 4.2 - Ilustração do processo de pirosequenciamento. Na imagem da esquerda observam-se as reações enzimáticas subsequentes a uma incorporação bem sucedida de um nucleotídeo ao molde de DNA fita-simples utilizado nesta técnica. Resumidamente, uma molécula de pirofosfato (PPi) é liberada após esta incorporação de nucleotídeo pela DNA polimerase e convertido em ATP pela sulfurilase; o ATP fornece energia para a luciferase induzir a emissão de luz pela luciferina. Esta emissão é registrada pelo equipamento em um gráfico, o pirograma. A direta observa-se o pirograma, em que as alturas dos picos do gráfico são proporcionais ao número de nucleotídeos idênticos incorporados ao molde de DNA.

Figura 5.1 - Ilustração das possíveis curvas de amplificação e os possíveis genótipos. A: amostra A12 apresenta duas curvas clássicas de amplificação - amostra heterozigota, B: D3 apresenta a curva clássica de amplificação apenas para o alelo marcado por $\mathrm{FAM}^{\circledR}$ amostra homozigota, C: C8 apresenta a curva clássica de amplificação apenas para o alelo marcado por VIC ${ }^{\Theta}$ - amostra homozigota. D: gráfico da discriminação alélica das amostras analisadas.

Figura 5.2 - llustração dos possíveis pirogramas obtidos a partir do pirosequenciamento. A: dois picos de intensidade intermediária e semelhate - amostra heterozigota (AC), B: pico único e com o dobro da altura dos anteriores - amostra homozigota (AA), C: pico único e com o dobro da altura dos anteriores - amostra homozigota (CC)..... 


\section{LISTA DE TABELAS}

Tabela 2.1 - Relação dos diferentes ligantes e localização dos TLR humanos

Tabela 4.1 - Dados dos SNP nos genes-alvo selecionados para genotipagem nos grupos caso (LPO, CEC de boca e CEC de laringe) e grupo controle, com base nos critérios de seleção dos SNP adotados para este estudo (posição do SNP, MAF e LD), a partir de SNP encontrados na revisão da literatura relacionada e na consultaão dos diferentes ligantes e localização dos TLR humanos

Tabela 4.2 - Sequência dos iniciadores para amplificação da região que contém o SNP de interesse, utilizados na reação de PCR convencional de amostras de DNA-teste, cujos produtos da amplificação foram sequenciados para a validação dos ensaios TaqMan para genotipagem selecionados para tais SNP em TLR.

Tabela 4.3 - Resumo das condições para a reação de PCR convencional de amostras de DNA-teste com os iniciadores desenhados para a validação dos ensaios TaqMan para genotipagem selecionados para tais SNP

Tabela 4.4 - Sequência dos iniciadores para amplificação da região que contém o SNP de interesse, utilizados na primeira reação de PCR convencional, no caso do SNP TLR1-rs5743618. Bem como dos iniciadores utilizados no pirosequenciamento deste SNP e do SNP TLR9rs5743836.

Tabela 4.5 - Resumo das condições para a reação de PCR convencional de amostras de DNA-teste com os iniciadores desenhados para a validação dos ensaios TaqMan para genotipagem selecionados para tais SNP

Tabela 5.1 - Características clínicas dos pacientes dos quais amostras congeladas de DNA, armazenadas no Laboratório de Genética da Faculdade de Medicina e Odontologia da Universidade do País Basco (UPV/EHU), foram incluídas nesta pesquisa. .54

Tabela 5.2 - Análise dos resultados da genotipagem do SNP TLR2-rs4696480, frequência e odds ratio de cada genótipo e análise estatística, das diferentes doenças estudadas (LPO, CEC de Boca, CEC de laringe) em relação aos controles.

Tabela 5.3 - Análise dos resultados da genotipagem do SNP TLR4-rs1927911, frequência e odds ratio de cada genótipo e análise estatística, das diferentes doenças estudadas (LPO, CEC de Boca, CEC de laringe) em relação aos controles.

Tabela 5.4 - Análise dos resultados da genotipagem do SNP TLR9-rs352139, frequência e odds ratio de cada genótipo e análise estatística, das diferentes doenças estudadas (LPO, CEC de Boca, CEC de laringe) em relação aos controles.

Tabela 5.5 - Relação entre a presença do alelo A do SNP TLR2-rs4696480 em pacientes com CEC de boca e as características clínicas: hábitos nocivos e estadiamento TNM.

Tabela 5.6 - Análise dos resultados da genotipagem do SNP TLR2-rs4696480, frequência e odds ratio de cada genótipo e análise estatística, das diferentes formas de LPO incluídas no estudo (LPO idiopático e LLO) em relação aos controles. 


\section{LISTA DE GRÁFICOS}

Gráfico 5.1 - Distribuição da localização primária das lesões de CEC de boca entre as amostras de pacientes incluídas nesta pesquisa....................................................................55

Gráfico 5.2 - Distribuição dos casos em relação ao estadiamento pelo sistema TNM (sendo T a extensão do tumor primário, $\mathrm{N}$ relacionado à metástase em linfonodos regionais e $\mathrm{M}$ metástase à distância) entre as amostras de pacientes incluídas nesta pesquisa......55

Gráfico 5.3 - Relação entre pacientes do sexo masculino e feminino nos grupos: LPO idiopático e

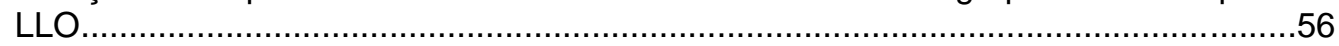

Gráfico 5.4 - Relação entre pacientes tabagistas, ex-tabagistas e não tabagistas nos grupos: LPO

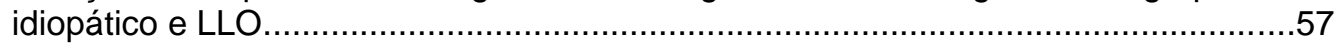

Gráfico 5.5 - Relação entre pacientes etilistas e não etilistas nos grupos: LPO idiopático e LLO...57 


\section{LISTA DE ABREVIATURAS E SIGLAS}

APC células apresentadoras de antígenos

ATP trifosfato de adenosina

BSA albumina de soro bovino

CAPES Coordenação de Aperfeiçoamento de Pessoal de Nível Superior

$\mathrm{CCL} \quad$ quimiocina ligante da família CC

CCR receptor para quimiocina ligante da família CC

CD grupamento de diferenciação

CD-14 antígeno de diferenciação de leucócito humano 14

CEC carcinoma epidermóide

c-Myc oncogene homólogo a mielocitomatose viral v-myc

CpG dinucleotídeo citosina-guanina

DC células dendríticas

DNA ácido desoxirribonucléico

dNTP desoxirribonucleotídeos fosfatados

dsRNA fita-dupla de ácido ribonucleico

EGFR receptor do fator de crescimento epidermal

ERBB-2 oncogene 2 homólogo a leucemia eritroblástica viral v-erb-b2

FOUSP Faculdade de Odontologia da Universidade de São Paulo

GVHD doença do enxerto contra o hospedeiro

HMGB1 proteína do grupo de alta mobilidade B1

HPV papilomavírus humano

H-ras oncogene da proteína transformadora p21

HSP proteína de choque térmico

hToll receptor Toll humano

HWE equilíbrio de Hardy-Weinberg

IC intervalo de confiança

IFN interferon

IHQ imunoistoquímica

IL-1R receptor para interleunina-1

INCA Instituto Nacional do Câncer

LD desequilíbrio de ligação 
LLO lesão liquenóide oral

LPO líquen plano oral

LPS lipopolissacarídeo

LRR domínio extra-celular dos TLR rico em repetições de leucina

LRR rico em repetições de leucinas

MAF menor frequência alélica

MD-2 antígeno linfocitário 96 - LY96

MyD88 fator de diferenciação mielóide 88

NF-kB fator nuclear kappa B

OMS Organização Mundial da Saúde

OR odds ratio - razão de chances

PAMP padrões moleculares associados a patógenos

PCR reação em cadeia da polimerase

PDEE Programa de Doutorado com Estágio no Exterior

poly I:C ácido polyinosinic-polycytidylic, agonista sintético do TLR3

$\mathrm{PPi} \quad$ pirofosfato

PRR receptores reconhecedores de padrões moleculares

qPCR reação em cadeia da polimerase em tempo real (quantitativa)

$\mathrm{RL} \quad$ reação liquenóide

RLC reação liquenóide de contato

RLD reação liquenóide a droga

RNAm ácido ribonucleico mensageiro

rs ref. SNP, número de referência do SNP

RT-PCR transcrição reversa prévia a reação em cadeia da polimerase

SNP polimorfismos de nucleotídeo único

Th linfócitos T auxiliares

TIL Toll / IL-1R

TIR domínio citoplasmático comum ao TLR e ao IL-1R

TIRAP/MAL proteína adaptadora contendo domínio TIR/adaptador similar ao MyD88

TLR receptores Toll-Like

TRAM molécula adaptadora relacionada ao TRIF

TRIF adaptador contendo o domínio TIR indutor de interferon- $\beta$

UPV/EHU Universidade do País Basco - Espanha

$\mathrm{X}^{2} \quad$ qui-quadrado 


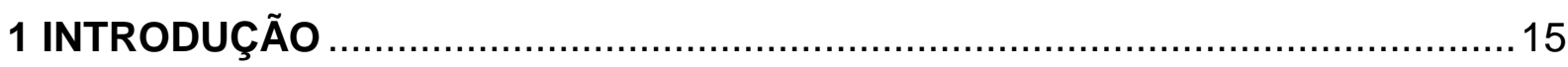

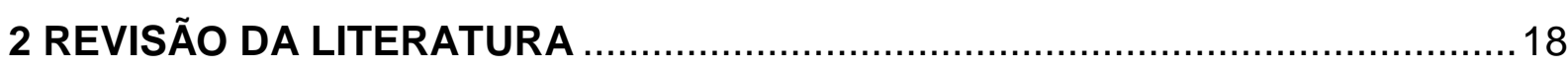

2.1 Receptores Toll-like e a Doença Liquenóide Oral, uma doença inflamatória crônica com possível potencial de transformação maligna.............................23

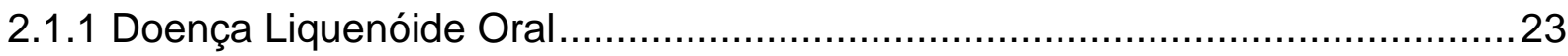

2.1.2 Estudo dos TLR em Doença Liquenóide Oral ...........................................2 27

2.2 Receptores Toll-like e câncer: da progressão tumoral ao tratamento .........28

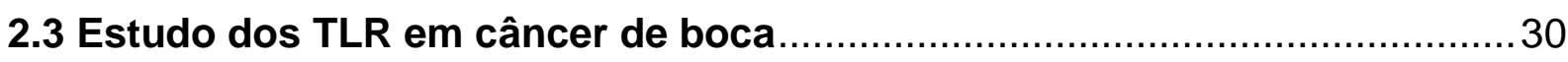

2.3.1 Câncer de boca ................................................................................... 30

2.3.2 Expressão gênica e proteica dos TLR em células tumorais de CEC de boca..31

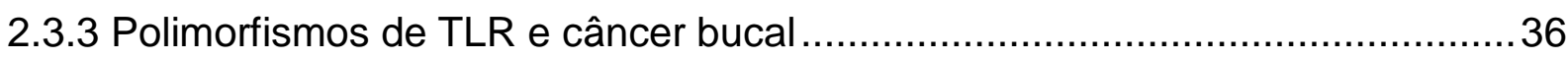

3 PROPOSIÇÃO

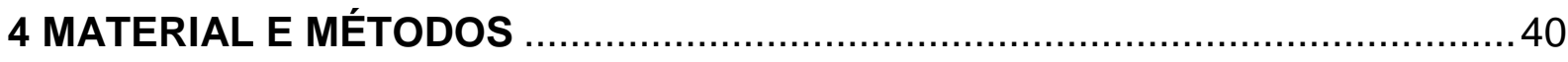

4.1 Amostras biológicas e dados dos pacientes ……..................................... 40

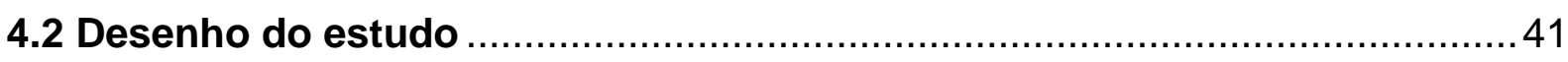

4.3 Seleção dos polimorfismos genéticos de um único nucleotídeo nos genes

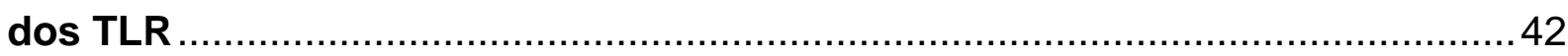

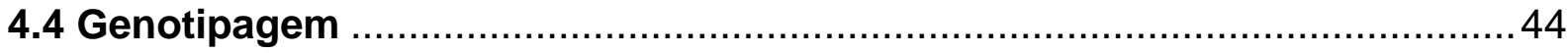

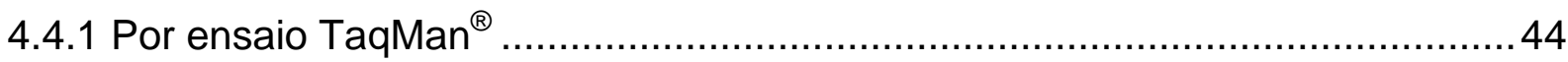

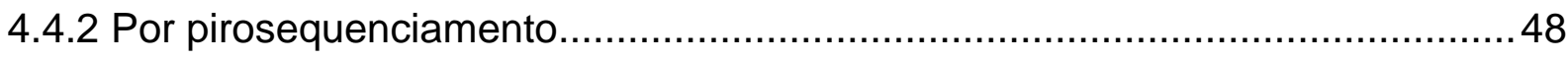

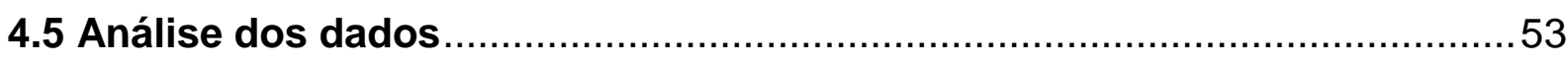

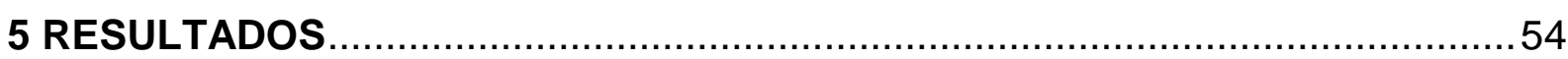

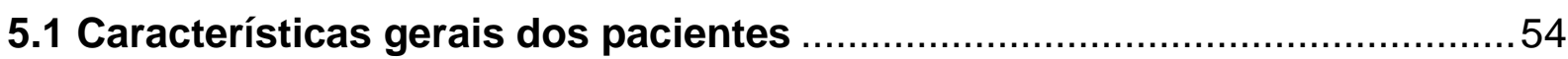

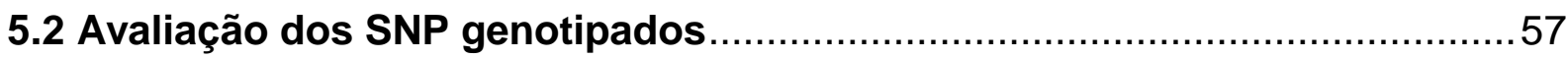

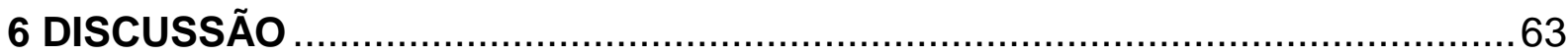

6.1 Considerações em relação à revisão de literatura realizada ......................63

6.2 Considerações em relação à análise da genotipagem dos SNP nos TLR....65

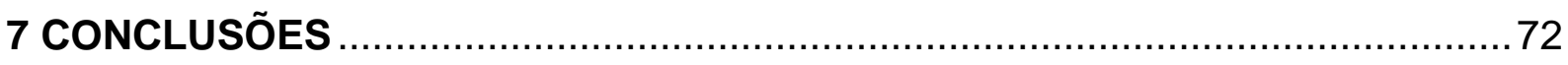

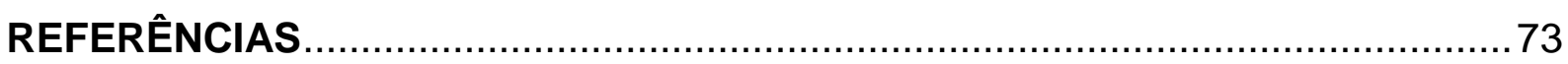

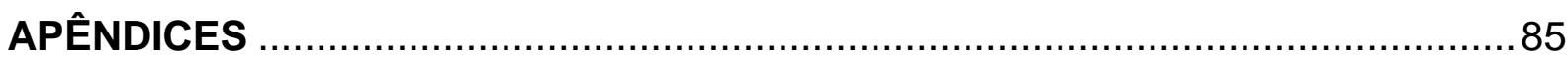

ANEXOS 


\section{INTRODUÇÃO}

Os receptores Toll-like (TLR) são responsáveis pela sinalização dos eventos que desencadeiam a resposta imunológica inata a partir do reconhecimento de produtos moleculares derivados de diferentes classes de microrganismos, tais como bactérias gram-positivas e gram-negativas, fungos, protozoários e vírus. A ativação dos TLR culmina com a produção de citocinas inflamatórias e quimiocinas, propiciando resposta inflamatória aguda e, consequentemente, estímulo inicial da resposta imunológica adaptativa, visto que estes receptores estão presentes em células apresentadoras de antígenos tais como as células dendríticas (1-4).

Esta relação entre os TLR, o reconhecimento de patógenos e o desencadeamento da resposta inflamatória é amplamente conhecida e estudada, mas anormalidades envolvendo as funções dos TLR podem explicar a resposta imunológica aberrante em diversas doenças. Além disso, existe emergente evidência de que os TLR reconhecem proteínas constitutivas do próprio organismo, relacionando estes receptores à etiologia de doenças autoimunes, doenças inflamatórias crônicas, e até mesmo do câncer (5-8).

Doenças inflamatórias crônicas bucais mediadas por linfócitos $T$, tal como o líquen plano oral (LPO), apresentam sinalização aberrante de TLR envolvida em sua etiopatogenia (8-12). Além disso, pacientes com LPO apresentam aumento da expressão de proteínas de choque térmico, que são proteínas próprias do organismo que atuam como possíveis antígenos para o desencadeamento da resposta inflamatória observada, via estimulação de TLR, como descrito anteriormente (13, 14).

Além de representar uma doença inflamatória crônica bucal que pode causar dor e desconforto; e assim impactar na qualidade de vida das pessoas acometidas; oficialmente, a Organização Mundial da Saúde (OMS) classifica o LPO como uma desordem potencialmente maligna, com risco não especificado de transformação maligna e sugere que pacientes com LPO devem estar em acompanhamento clínico periódico e constante. Apesar de ser um campo bastante controverso, visto que existem relatos de transformação atingindo de 0 a $5.3 \%$ dos pacientes, classicamente, as lesões atróficas, erosivo-ulceradas e atípicas de LPO são as que apresentam maior risco de transformação maligna. Esta circunstância 
pode estar relacionada à presença de maior resposta inflamatória crônica, de forma semelhante a outras doenças inflamatórias associadas também a neoplasias malignas, tal como a doença inflamatória intestinal e esofagite crónica (15-17).

A relação entre infecção, inflamação e o desenvolvimento de neoplasias malignas é descrita desde o século 19, a partir dos avanços propiciados pelo patologista alemão Rudolf Virchow. De fato, alguns tipos de câncer tem seu surgimento relacionado a inflamação crônica causada por agentes infecciosos, como por exemplo: câncer gástrico e Helicobacter pylori, câncer cervical e papilomavírus humano, hepatocarcinoma e hepatite $C(7,18-20)$.

Evidências recentes demonstraram alterações nos TLR implicadas no crescimento, progressão e agressividade de tumores, e na imunossupressão, que permite o escape do controle imunológico de células malignas numa grande variedade de tumores, incluindo as neoplasias malignas de mama, cólon, próstata, pulmão, estômago, esôfago e nasofaringe (20-22).

A cavidade bucal está cronicamente exposta a uma variedade de agentes patogênicos, alvos clássicos dos TLR. Contudo, a relação entre estes receptores e o desenvolvimento do câncer de boca pode ser proporcionada também pela ativação destes receptores por irritantes tóxicos provenientes do tabaco e do álcool, que por sua vez constituem os fatores de risco clássicos para o câncer de boca. Ou ainda pela inflamação crônica resultante do reconhecimento de proteínas próprias do organismo humano que desencadeiam doenças inflamatórias bucais, como o líquen plano oral, provável desordem oral potencialmente maligna (15, 23-27).

Finalmente, alterações funcionais destes receptores podem ser induzidas pela herança de mutações nos genes que codificam os TLR. Dentre os diversos tipos de mutações existentes, os polimorfismos representam uma variação fenotípica proporcionada pela presença de mutação que provoca alteração na sequência de bases nitrogenadas do DNA, sendo responsável pela variação genética entre os indivíduos (28). Os polimorfismos mais comumente conhecidos são: sistema ABO de grupos sanguíneos (29), variação destro/canhoto (30) e a presença ou não do terceiro molar (31). Por exemplo, no caso do sistema ABO de grupos sanguíneos, são encontradas quatro diferenças na sequência de nucleotídeos entre os alelos $\mathrm{A}$ e $B$ que resultam em mudanças de aminoácidos, o que altera a especificidade da enzima codificada por este gene ABO (29). 
O polimorfismo de nucleotídeo único (SNP) é um dos tipos mais comuns de polimorfismo, em que existe a substituição de um único nucleotídeo e que o alelo menos frequente (mutante) ocorre a uma taxa superior a um por cento numa população. É a forma mais comum de variação genética humana, e o principal banco de dados de polimorfismos (dbSNP - GenBank $-\mathrm{NCBI}^{1}$ ) atualmente contém mais de 5.000.000 de SNP validados em seres humanos. Atualmente sabe-se que podem estar relacionados à susceptibilidade de desenvolvimento de doenças complexas e à variação da resposta de cada indivíduo a um determinado tipo de tratamento. A combinação de diversas variações genéticas do tipo SNP e a atuação do meio ambiente, então, provocariam o desenvolvimento de doenças complexas como o câncer (28).

Polimorfismos em TLR, responsáveis pela resposta imunológica inata, poderiam modificar a susceptibilidade a patógenos comensais, agentes irritantes e tóxicos, ou a proteínas próprias do organismo. Alterando a habilidade da resposta imunológica adaptativa quanto à tolerância imunológica e ao restabelecimento do equilíbrio homeostático do sistema imune, levando ao desenvolvimento dos mais variados $(7,20,21)$.

Esses fatos suscitaram o desenvolvimento deste estudo voltado à avaliação da herança de polimorfismos nos genes dos receptores Toll-Like em população com doença inflamatória crônica bucal, líquen plano oral, e população com câncer de boca, buscando contribuir com o esclarecimento da etiopatogenia destas doenças.

\footnotetext{
${ }^{1}$ http://www.ncbi.nlm.nih.gov/snp
} 


\section{REVISÃO DA LITERATURA}

Vinte e sete anos atrás, os primeiros genes Toll foram descobertos pela bióloga alemã Christiane Nüsslein-Volhard pela observação de defeitos morfológicos importantes em larvas de moscas-de-fruta (Drosophila melanogaster) quando apresentavam mutação em determinado gene, de função ainda desconhecida, e exclamou "Das war ja toll!", que em português significa "Isso foi estranho/fantástico". Este gene foi, então, designado gene Toll e associado à polaridade dorso-ventral durante o desenvolvimento embrionário destas moscas; esta descoberta em conjunto a outras no campo da embriogênese da mosca-de-fruta conferiram a esta pesquisadora o Prêmio Nobel em Fisiologia ou Medicina em 1995 (32, 33).

Em 1991, Gay e Keith observaram que o receptor para interleucina-1 (IL1R) compartilhava extensa homologia, especialmente em relação à porção citoplasmática, ao gene Toll descrito na mosca-de-fruta, denominado domínio TIR (Toll/ Interleucina-1 Receptor) (34).

Uma década após a descoberta do gene Toll, estudos do laboratório do biólogo francês Jules Hoffmann demonstraram que a reação imunológica das moscas adultas frente à infecção fúngica era sinalizada de maneira dependente da via do gene Toll, revelando outra e essencial função deste gene nestas moscas, o controle da resposta imunológica inata (35).

E, então, em 1997 foi identificado, por Medzhitov et al., a homologia entre a proteína codificada pelo gene Toll da Drosophila melanogaster e uma proteína humana, denominada inicialmente hToll (Toll humano). Da mesma maneira que na mosca-de-fruta, tratava-se de um receptor transmembrana tipo I, com um domínio extracelular rico em repetições de leucinas (LRR), e um domínio citoplasmático, previamente descrito, homólogo ao do IL-1R (TIR). Comprovou-se, dessa forma, que a resposta imunológica mediada por estes receptores é um mecanismo de defesa primitivo altamente conservado, presente em plantas, insetos e vertebrados (36).

Esta relação com a resposta imunológica foi confirmada por Beutler e colaboradores, relacionando este receptor ao reconhecimento de lipopolissacarídeo (LPS); importante endotoxina bacteriana; e à regulação da resposta imunológica. $\mathrm{E}$ este receptor, inicialmente designado como $\mathrm{h}$ Toll, foi um ano mais tarde denominado receptor Toll-Like 4 (TLR4), por ser semelhante ("like", em inglês) ao gene Toll da 
mosca-de-fruta. $(37,38)$. Isto porque, este receptor era cronologicamente, o quarto homólogo à proteína Toll da Drosophila identificado.

O primeiro receptor desta família foi identificado em 1994 por Nomura et al., mapeado no cromossomo humano em 1996 por Taguchi et al. e denominado TIL (Toll/ receptor InterLeucina-1). Inicialmente havia sido equivocadamente relacionado ao desenvolvimento embrionário de mamíferos, como na mosca de frutas, porém com a descoberta de Medzhitov e seu tutor Charlie Janeway, foi também atribuído à resposta imunológica e hoje é conhecido como $\operatorname{TLR} 1(39,40)$.

Estas descobertas acerca dos receptores Toll-Like (TLR) e sua importante relação com a resposta imunológica conferiram aos pesquisadores Jules Hoffmann e Bruce Beutler o último - e controverso - Prêmio Nobel em Fisiologia ou Medicina (2011), deixando à margem e criando descontentamentos por excluir outros importantes pesquisadores que contribuíram com o desvendamento deste campo na ciência; como Lemaitre, que conduziu as pesquisas que relacionaram o gene Toll à resposta imunológica (35), e Medzhitov e seu mentor Charlie Janeway, que identificaram a homologia do gene Toll da mosca-de-fruta com o de seres humanos (36), gerando reportagens ${ }^{2}$ e editoriais sobre esta polêmica em importantes revistas científicas, como Science e The Lancet (41).

Atualmente, 10 TLR estão identificados em seres humanos. A família dos TLR é uma das maiores e mais bem estudadas classes de receptores responsáveis pelo reconhecimento de padrões (PRR), mais especificamente, padrões moleculares associados a patógenos (PAMP), os quais são derivados de um amplo espectro de agentes infecciosos, como bactérias gram-positivas e gram-negativas, vírus, protozoários e fungos. Esta interação PRR-PAMP propicia o desencadeamento da resposta imunológica inata (3).

Alguns TLR estão localizados na membrana citoplasmática de diversos tipos celulares, especialmente em células apresentadoras de antígenos (APC) como as células dendríticas (DC) e macrófagos, são eles os TLR1, TLR2, TLR4, TLR5, TLR6 e TLR10. Enquanto os restantes, TLR3, TLR7, TLR8 e TLR9 estão localizados intracelularmente em endossomos (4).

\footnotetext{
${ }^{2}$ http://scienceblogs.com/webeasties/2011/10/06/a-bitter-sweet-nobel-beutler/ http://news.sciencemag.org/scienceinsider/2011/12/nobel-prize-for-immunologists.html\#more
} 
Nem sempre os TLR atuam isoladamente no reconhecimento de PAMP e desencadeamento da resposta imunológica. O TLR2 forma heterodímeros com outros TLR (TLR1, TLR6 e TLR10) para o reconhecimento de diferentes tipos de PAMP de acordo com cada heterodímero formado. Já o TLR3 e o TLR4, desempenham suas funções como homodímeros; e este último ainda necessita duas moléculas acessórias: MD-2 (antígeno linfocitário 96 - LY96) e CD-14 (antígeno de diferenciação de leucócito humano 14) (42).

A porção externa do receptor, LRR, é N-terminal e contém aproximadamente 19-25 resíduos de hidrofóbicos de leucina dispostos espacialmente em forma de ferradura e espaçados em intervalos distintos, caracterizando cada TLR. O reconhecimento dos PAMP ocorre na superfície ascendente lateral do ectodomínio do $\operatorname{TLR}(42,43)$.

A partir desta interação receptor-ligante, há a ativação do domínio citoplasmático TIR, que atua em conjunto com diferentes moléculas adaptadoras, tais como: fator de diferenciação mielóide 88 (MyD88), proteína adaptadora contendo domínio TIR/adaptador similar ao MyD88 (TIRAP/MAL), adaptador contendo o domínio TIR indutor de interferon- $\beta$ (TRIF), e molécula adaptadora relacionada ao TRIF (TRAM). Por sua vez, estas moléculas adaptadoras fornecem a estrutura necessária para recrutar e ativar a transcrição de fatores que regulam a resposta inflamatória pela ativação da via de sinalização que culmina com a ativação do fator nuclear kappa B (NF-KB) e a consequente produção de citocinas inflamatórias e quimiocinas (via dependente de MyD88, sendo o TIRAP uma molécula associada à ativação do MyD88 no caso do TLR2) ou de interferon (IFN) tipo I (IFN- $\alpha$ / $\beta$ ) (via dependente de TRIF, sendo o TRAM uma molécula associada à ativação do TRIF no caso do TLR4). Todos os TLR executam sua função pela via dependente de MyD88, exceto o TLR3, que a executa exclusivamente pela via dependente de TRIF, a qual também é utilizada pelo TLR4 $(4,43)$.

A figura a seguir (Figura 2.1) ilustra a cascata mediada pela ativação dos TLR que culminam com a ativação da resposta imunológica inata $(4,21,43)$. 


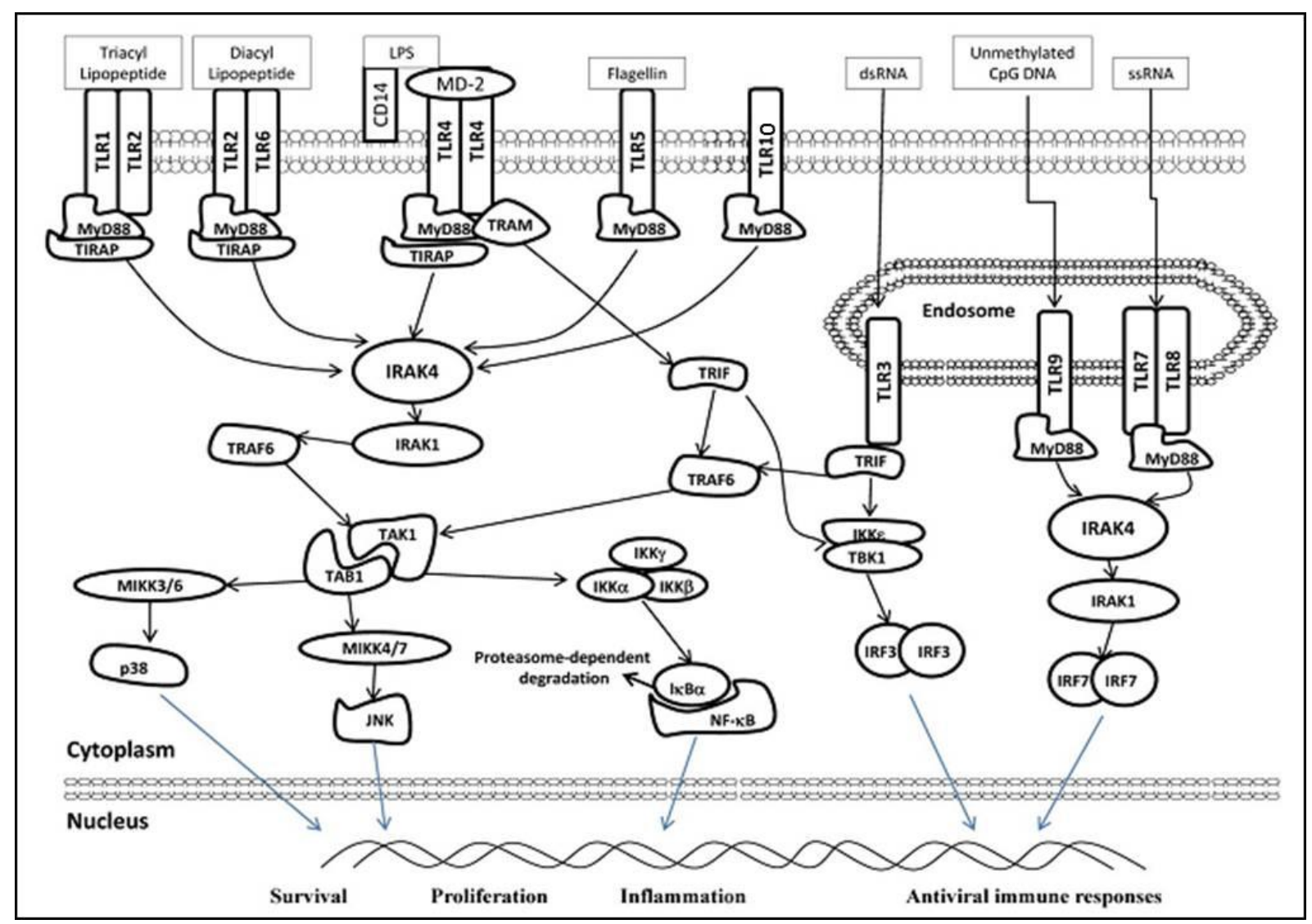

Figura 2.1 - Diagrama das vias de sinalização dos TLR. Estes receptores localizam-se em diferentes compartimentos nas células humanas de acordo com os ligantes correspondentes. Os TLR2, TLR4, TLR6, TLR5, TLR10 estão localizados na membrana plasmática, enquanto os TLR3, TLR7, TLR8 e TLR9 estão localizados nos endossomos. O TLR2 forma heterodímero com os TLR1, TLR6 e TLR10. CD14 e MD-2 são proteínas acessórias necessárias para que o TLR4 execute suas funções. Após o reconhecimento de seus respectivos ligantes, os TLR recrutam moléculas adaptadoras a sua porção intracelular, como MyD88 (exceto TLR3) e TRIF (TLR3 e TLR4), para ativar IRAK4, TRAF6 e IKK. A sequencia da ativação destas moléculas ativa por sua vez a via de sinalização do NK-kB, MAPK e IRF, que induz a transcrição do DNA para produção de uma série de respostas celulares específicas relacionadas com a proliferação celular, sobrevivência e inflamação, com a produção de citocinas próinflamatórias e interferon do tipo I (no caso das respostas antivirais). MyD88: fator de diferenciação mielóide 88; TIRAP: proteína adaptadora contendo domínio intracelular TIR; TRAM: molécula adaptadora relacionada ao TRIF; TRIF: adaptador contendo o domínio TIR indutor de interferon- $\beta$; IRAK:quinase associada ao receptor de IL-1; TRAF: fator associado ao receptor de TNF; IKK: inibidor kappa quinase; TBK TAK: quinase ativada pelo TGF; TAB: proteína de ligação a TAK; IRF: fator regulador do interferon; MIKK (MAPK): proteína quinase ativada por mitógeno p38 e JNK; JNK: quinase c-Jun N-terminal; NF-kB: factor nuclear kappa B

Fonte: So e Ouchi, 2010 (21). 
A tabela a seguir (Tabela 2.1) sintetiza os diferentes tipos de PAMP reconhecidos pelos TLR e o tipo celular em que estes receptores estão presentes (5, $42,43)$.

Tabela 2.1 - Relação dos diferentes ligantes e localização dos TLR humanos.

\begin{tabular}{|c|c|c|c|}
\hline Receptor & Ligante (PAMP) & Origem do PAMP & $\begin{array}{l}\text { Tipos celulares } \\
\end{array}$ \\
\hline TLR1 & Triacil-lipopeptídeos & Bactérias & $\begin{array}{c}\text { Monócitos, macrófagos, células } \\
\text { dendríticas, linfócitos B }\end{array}$ \\
\hline TLR2 & $\begin{array}{c}\text { Lipopeptídeos } \\
\text { Ácido lipoteicóico } \\
\text { Zymosan }\end{array}$ & $\begin{array}{c}\text { Bactérias } \\
\text { Bactérias gram-positivas } \\
\text { Fungos } \\
\end{array}$ & $\begin{array}{c}\text { Monócitos, macrófagos, células } \\
\text { dendríticas mielóides, } \\
\text { mastócitos }\end{array}$ \\
\hline TLR3 & Fita dupla de RNA & Vírus & Células dendríticas, linfócitos $B$ \\
\hline TLR4 & Lipopolissacarídeos & $\begin{array}{l}\text { Bactérias gram- } \\
\text { negativas }\end{array}$ & $\begin{array}{l}\text { Monócitos, macrófagos, células } \\
\text { dendríticas mielóides, } \\
\text { mastócitos, linfócitos } B \text {, células } \\
\text { do epitélio intestinal }\end{array}$ \\
\hline TLR5 & Flagelina & Bactéria & $\begin{array}{l}\text { Monócitos, macrófagos, células } \\
\text { dendríticas, células do epitélio } \\
\text { intestinal }\end{array}$ \\
\hline TLR6 & Diacil-lipopeptídeos & Bactérias & $\begin{array}{c}\text { Monócitos, macrófagos, } \\
\text { mastócitos, linfócitos B }\end{array}$ \\
\hline TLR7 & Fita simples de RNA & Vírus & $\begin{array}{c}\text { Monócitos, macrófagos, células } \\
\text { dendríticas plasmocitóides, } \\
\text { linfócitos B }\end{array}$ \\
\hline TLR8 & Fita simples de RNA & Vírus & $\begin{array}{c}\text { Monócitos, macrófagos, células } \\
\text { dendríticas, linfócitos B }\end{array}$ \\
\hline TLR9 & $\begin{array}{l}\text { DNA não metilado rico } \\
\text { em } \mathrm{CpG}^{*}\end{array}$ & $\begin{array}{l}\text { Bactérias } \\
\text { Vírus }\end{array}$ & $\begin{array}{c}\text { Monócitos, macrófagos, células } \\
\text { dendríticas plasmocitóides, } \\
\text { linfócitos B }\end{array}$ \\
\hline TLR10 & Lipopeptídeos & Bactérias & $\begin{array}{c}\text { Monócitos, macrófagos, células } \\
\text { dendríticas, linfócitos B }\end{array}$ \\
\hline
\end{tabular}

É amplamente conhecida e estudada a resposta imunológica mediada pelos TLR a partir de estruturas específicas de agentes patogênicos, bem como o desencadeamento de resposta imune adaptativa por meio das células DC ou de outras APC. No entanto, existe emergente evidência de que os TLR podem reconhecer proteínas constitutivas do próprio organismo, participando então na sinalização relacionada a doenças autoimunes e doenças inflamatórias crônicas. As proteínas humanas mais comumente reconhecidas pelos TLR são as do grupo de alta mobilidade B1 (HMGB1) e as proteínas de choque térmico (HSP). O reconhecimento de proteínas próprias do organismo pode levar ao desencadeamento de diversos tipos de doenças, tais como as doenças autoimunes, as doenças inflamatórias e inflamações crônicas, e até mesmo o câncer $(5,6)$. 


\subsection{Receptores Toll-like e a Doença Liquenóide Oral, uma doença inflamatória crônica com possível potencial de transformação maligna}

\subsubsection{Doença Liquenóide Oral}

O líquen plano oral (LPO) é uma doença mucocutânea inflamatória crônica, que apresenta etiologia desconhecida e tende a ser refratária ao tratamento. O LPO acomete de 1 a $4 \%$ da população mundial, geralmente indivíduos de meia-idade, leucodermas e do sexo feminino (44).

Clinicamente, o líquen plano caracteriza-se por erupções papulares em pele e mucosas, particularmente as mucosas bucal e genital e, mais raramente, nas mucosas anal, nasal, ocular, da laringe e da uretra. O acometimento da mucosa bucal ocorre em 50 a $70 \%$ dos pacientes com líquen plano e podem ser exclusivas em 20 a $30 \%$ dos pacientes (45).

O LPO é uma doença idiopática e polimorfa, apresentando diversas formas clínicas: reticular, atrófica, erosiva, em placa e bolhosa; que podem estar presentes simultaneamente em um mesmo paciente. A forma reticular é a mais comum, e caracteriza-se por uma rede entrelaçada de linhas esbranquiçadas (estrias de Whickham), acometendo geralmente a mucosa jugal de forma bilateral e simétrica. $\mathrm{O}$ quadro histopatológico é caracterizado pela presença de hiperqueratose, degeneração hidrópica da camada basal e um infiltrado inflamatório subepitelial linfocítico disposto em banda; queratinócitos necróticos (corpos de Civatte) podem ser observados e completam este quadro (46-48)

Alguns outros tipos de lesões se assemelham clinica e histologicamente ao LPO idiopático, porém diferem deste por apresentar um fator etiológico bem caracterizado, tais como a reação liquenóide à drogas (RLD), a reação liquenóide por doença do enxerto contra o hospedeiro (RL por GVHD) e a reação liquenóide de contato (RLC). Na RLD o fator precipitante é o uso de medicações sistêmicas, tais como: anti-hipertensivos, diuréticos, hipoglicemiantes orais, antiinflamatórios não esteroidais; seu correto diagnóstico é complexo uma vez que nem sempre é possível interromper o uso desta medicação para a observação da remissão da lesão como prova diagnóstica. Já a RL por GVHD pode ser comprovada facilmente pela história 
clínica de realização de transplante e presença de GVHD; e a RLC, provocada por materiais restauradores odontológicos, especialmente pelo amálgama, pode ser comprovada pela regressão da lesão após substituição do material restaurador (47).

Além disso, existem algumas situações clínicas que não apresentam relação com drogas, materiais restauradores ou reação a transplantes; e que também não contemplam as características de lesões múltiplas, simétricas e bilaterais características do diagnóstico de LPO idiopático, constituindo um grupo de lesões classificado como lesões liquenóides orais (LLO). Também estão incluídas neste grupo as lesões que clinicamente são características, porém não apresentam todos os critérios para o diagnóstico histológico do LPO $(15,49,50)$.

Todas estas condições semelhantes parecem fazer parte de um mesmo grupo desde que a presença de estrias brancas em mucosa de cavidade bucal não é característica patognomônica do LPO idiopático. Desta forma, Aguirre-Urizar propõe uma nova classificação a esta condição: doença liquenóide oral (DLO); subdividida, de acordo com os diversos tipos de lesões, em: líquen plano mucocutâneo (pele e mucosas), líquen plano mucoso (diferentes mucosas), LPO idiopático, líquen plano reacional (RLD, RL por GVHD, RLC) e LLO (50).

Esta subdivisão e o correto diagnóstico e classificação, bem como o acompanhamento dos pacientes que apresentam DLO tem grande importância em virtude do relativo potencial de transformação maligna desta condição. Os critérios que norteiam o diagnóstico desta condição consideram características clínicas e histológicas, baseadas nas postulações da OMS modificadas por Van der Meij e Van der Waal (45), e se encontram sumarizados na figura a seguir (Figura 2.2).

A porcentagem de indivíduos acometidos por DLO que apresentam transformação maligna varia de 0 a $6.25 \%$ dos pacientes, de acordo com os resultados da revisão de estudos observacionais prospectivos e retrospectivos acerca da transformação maligna em casos de DLO de 1985 a 2004, publicada por Lodi et al. (17). Após um encontro de importantes pesquisadores em 2003 para a produção de um documento de consenso em relação a diversos aspectos da DLO, com base na literatura recente publicada em revistas internacionais com revisão por pares, considerou-se que as lesões atróficas, erosivo-ulceradas e atípicas da DLO, desta forma as LLO apresentariam maior potencial de transformação maligna. 


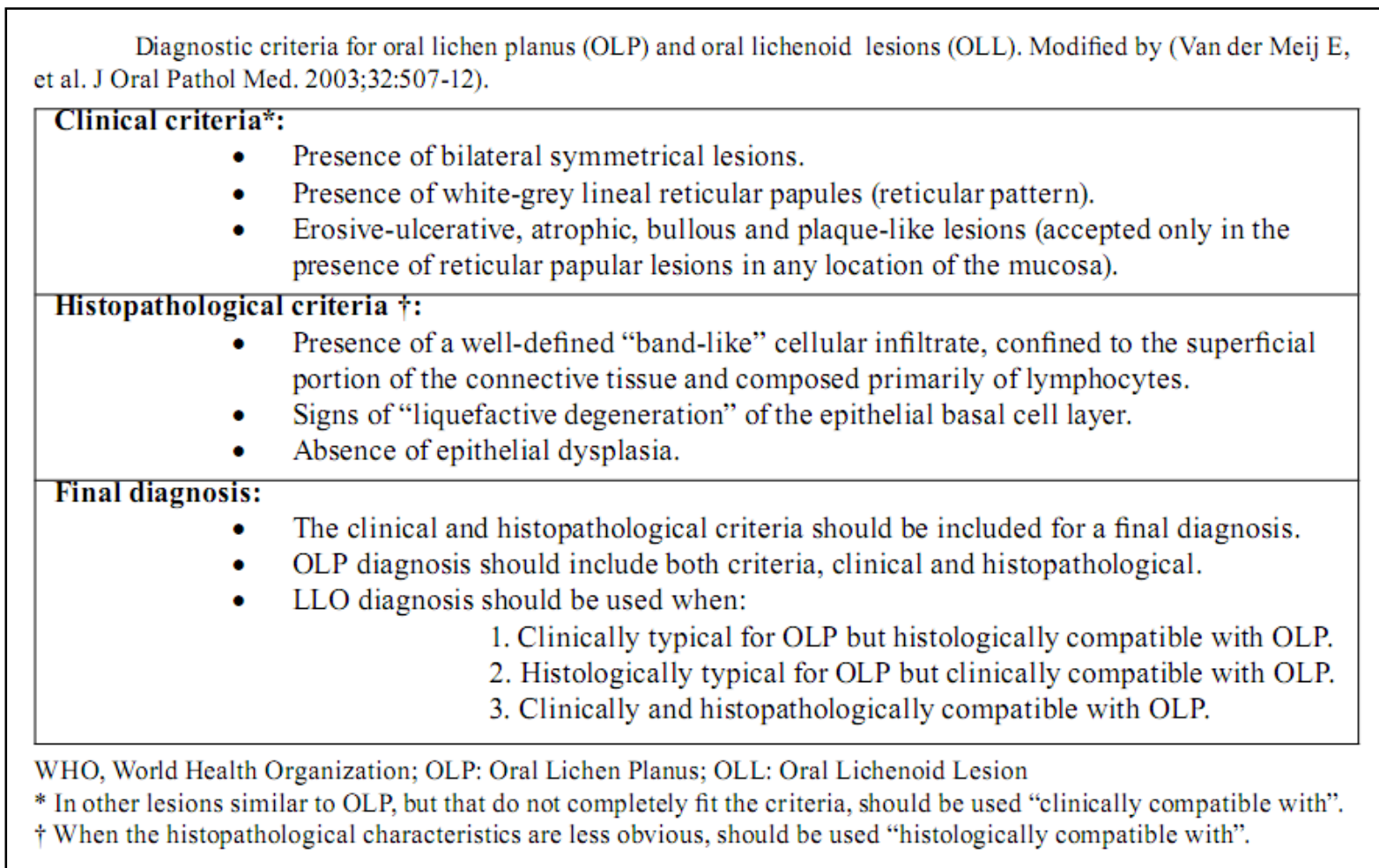

Figura 2.2 - Esquematização dos critérios de diagnóstico do LPO estabelecidos pela Organização Mundial da Saúde e modificados por Van der Meij e Van der Waal (2003) em relação às características clínicas e histológicas

Fonte: Cortés-Ramíres et al., 2009 (15)

A classificação da DLO como uma desordem oral potencialmente maligna é um tema ainda bastante controverso, e motiva inúmeras investigações, especialmente no campo da biologia molecular genética e epigenética. A aneuploidia, um fenômeno associado a lesões malignas e potencialmente malignas, como a leucoplasia verrucosa proliferativa $(51,52)$, não parece um evento comum na DLO. Porém, o uso da citometria de imagem de DNA a partir de esfregaços da mucosa bucal representa um método fácil e útil no acompanhamento de pacientes com DLO, uma vez que portadores das formas atróficas e erosiva da DLO tendem a apresentar maior porcentagem de células tetraplóides (53).

Resultados semelhantes foram encontrados em relação à perda de heterozigosidade, mais frequentemente observada em leucoplasias com displasia em relação à DLO (54). As análises da expressão do gene supressor de tumor p53 em DLO apresentam resultados conflitantes. A maioria das investigações revelou aumento da expressão do p53 no epitélio afetado pela DLO em relação à mucosa bucal normal. No entanto, não há consenso sobre o mecanismo que poderia explicar 
este achado. Supõe-se que esta ativação serviria para proteger o epitélio frente ao crônico e intenso ataque linfocitário (55).

Esta controvérsia também se deve ao desconhecimento da etiologia da DLO. Embora diversos fatores tenham sido relacionados com seu surgimento, tais como: aspectos genéticos (14), materiais restauradores odontológicos (56), medicamentos sistêmicos (14), agentes infecciosos (infecção por hepatite C) (57, 58), auto-imunidade e deficiências imunológicas (59), alergia a alimentos (especialmente canela e frutos do mar), hábito de mascar tabaco, estresse (14) e diabetes (60).

Existem evidências que pacientes com DLO apresentam alterações na resposta imunológica mediada por células. A maior parte dos linfócitos $T$ acumulados no infiltrado inflamatório subjacente à camada de queratinócitos basais danificados, presente no DLO, são linfócitos T CD8+ (citotóxicos). A ligação do antígeno, ainda desconhecido, a moléculas apresentadoras de antígenos do $\mathrm{MHC}-1$ em queratinócitos ativaria linfócito T CD8+, desencadeando a resposta imunológica que culmina com apoptose dos queratinócitos e, consequentemente, com o dano epitelial $(14,59,61)$.

Estes linfócitos T CD8+ ativados liberam quimiocinas que atraem linfócitos adicionais para a lesão de DLO em desenvolvimento, retroalimentando o processo (59). A estimulação de mastócitos via quimiocina CCL5 secretada pelos linfócitos T CD8+, proporciona a liberação de TNF- $\alpha$ que, por sua vez, provoca o aumento da expressão da CCL5 caracterizando um mecanismo cíclico que confere a cronicidade ao LPO. Os receptores para esta quimiocina, CCR1, CCR3, CCR4, CCR5, CCR9 e CCR10 também foram identificados na DLO (62).

Proteínas de choque térmico (HSP) são altamente expressas pelos queratinócitos de pacientes com DLO e são relacionadas como possíveis antígenos para o desencadeamento da resposta inflamatória observada. Porém, o aumento da expressão destas pode fazer parte de uma via de sinalização que conecta uma grande variedade de agentes exógenos (medicamentos sistêmicos, materiais restauradores alergênicos, trauma mecânico, infecção bacteriana ou viral) na patogênese do DLO, como a via de sinalização dos TLR, abordada na próxima sessão $(13,14)$. 


\subsubsection{Estudo dos TLR em Doença Liquenóide Oral}

Poucos estudos avaliaram a participação dos TLR na DLO, mesmo no LPO idiopático. Os estudos incluídos na revisão são bastante recentes e indicam que este constitui um amplo campo aberto às investigações. Além disso, na maior parte destes estudos, os critérios de inclusão dos indivíduos nos estudos são detalhados, em relação aos critérios para o diagnóstico da DLO, e referem que as amostras são de pacientes com LPO.

A identificação de formas solúveis de TLR na saliva, provenientes de células epiteliais bucais descamadas, representa uma importante fonte de informação das macromoléculas que conferem perfil fisiopatológico ao epitélio oral observado. Constatou-se que as células epiteliais orais presentes na saliva de pacientes com LPO apresentam expressão gênica elevada de CD14 e reduzida de TLR2 (10).

A análise da expressão gênica e proteica em amostras de LPO, por RTPCR e imunoistoquímica, também demonstrou redução na expressão do TLR2 em conjunto com o aumento do TLR4 (9).

A diminuição da atividade ou da expressão do TLR2 interfere em sua atividade inibitória da resposta imunológica Th1, culminando na desregulação do equilíbrio inflamatório e, como consequência, um aumento exagerado da produção de citocinas inflamatórias. Além disso, foi recentemente demonstrado que a inflamação mediada por TLR é um pré-requisito para a ativação de linfócitos T autoreativos (63).

Aparentemente, o TLR4 encontra-se com expressão aumentada nas lesões de LPO, e sua ativação excessiva inicia a sinalização que conduz à indução do NF$k B$, e, consequentemente, de citocinas pró-inflamatórias e quimiocinas. Esta via de sinalização TLR4 e NF-kB pode estar associada aos processos de perpetuação das lesões e resistência à apoptose. A resistência à apoptose parece atuar como mecanismo de proteção da destruição de queratinócitos em ambas lesões de LPO atrófica-erosiva e reticular, tendo em vista que estes pacientes apresentam níveis elevados de expressão de proteínas pró-apoptose (64). Entretanto, as consequências de efeito anti-apoptótico excessivo são desconhecidas. 
Sabe-se que o TLR9, principalmente expresso por células dendríticas plasmocitóides presentes em lesões de pele de pacientes com doença auto-imune, apresenta sua expressão aumentada em portadores de LPO. Estas células ativadas apresentam a capacidade de produzir simultaneamente os altos níveis de importantes citocinas Th1, como IFN e IL-12 (11).

Pacientes com líquen plano cutâneo apresentam redução significativa da expressão proteica do TLR7, independentemente de estarem ou não infectados por hepatite C (65). Estes também apresentam uma redistribuição dos TLR1 e TLR2, mais expressos na camada basal do epitélio das lesões de líquen plano cutâneo, embora apresentem expressão reduzida em relação ao controle normal (66). A avaliação do TLR7, até o momento, não foi determinada no LPO; e apesar de também apresentar baixa expressividade do TLR2, sua localização no epitélio também é desconhecida.

A sinalização aberrante de TLR, criticamente envolvida no desenvolvimento de diversas doenças mediadas imunologicamente, como o LPO, pode ser resultado de polimorfismos em TLR que modifiquem a susceptibilidade às respostas a patógenos comensais, alterando a habilidade da resposta imunológica adaptativa quanto à tolerância imunológica e ao restabelecimento do equilíbrio homeostático do sistema imune. Porém não existem estudos na literatura que investiguem a herança de polimorfismos nos genes de TLR e o LPO.

\subsection{Receptores Toll-like e câncer: da progressão tumoral ao tratamento}

Os TLR também são expressos por células tumorais (22). Esta correlação foi primeiramente percebida em 1890, pelo cirurgião e pesquisador norte-americano William Coley, antes mesmo da identificação destes receptores, quando observou que pacientes com câncer que desenvolviam algumas infecções, especialmente erisipela (infecção cutânea causada geralmente pela bactéria Streptococcus pyogenes), apresentavam regressão do tumor maligno. Coley, convencido da possibilidade de tratamento do câncer com bactérias, imaginando que a infecção ativaria o sistema imunológico a combater as células neoplásicas juntamente com a infecção, criou uma mistura de infusões bacterianas, conhecida como Toxinas-Coley 
ou vacinas-Coley, e realizou um ensaio clínico para demonstrar essa relação com resultados inconsistentes e perigosos, que o levaram ao ostracismo (67).

Em 1998, apenas um ano após a identificação do TLR no ser humano, Bruce Buetler e colaboradores demonstraram que o LPS, uma toxina produzida por bactérias do gênero Streptococcus, ativava o sistema imunológico através do TLR4 e que essa interação poderia eliminar células, inclusive tumorais (37). Hoje em dia, Coley é reconhecido como um pioneiro na imunoterapia para o tratamento de câncer; e os TLR se tornaram alvo de pesquisa no desenvolvimento de drogas antitumorais $(37,67)$.

Inicialmente postulou-se que os TLR estariam relacionados à resposta imunológica antitumoral, tendo em vista que estes receptores desempenham papel fundamental na ativação da resposta imune inata. Desta forma, o funcionamento inadequado dos TLR impediria o reconhecimento das células tumorais pelo sistema imunológico e, consequentemente, sua permanência e progressão do tumor $(3,6)$. No entanto, alguns tipos de câncer parecem ter sua progressão sustentada pela inflamação crônica propiciada pela estimulação de TLR. Essa dualidade na função dos TLR se assemelha a uma "espada de dois gumes" $(22,68,69)$.

Ainda assim, a relação entre a inflamação crônica, mediada por TLR, e o risco de desenvolvimento de neoplasias malignas e a progressão tumoral é um vasto campo de investigação com resultados interessantes e promissores, mesmo para uma melhor compreensão da atuação de moléculas já estudadas na etiologia do câncer. Como por exemplo, a HMGB1, um componente endógeno da cromatina que se encontra altamente expresso em uma variedade de tumores, proporciona a produção de citocinas que estimulam a progressão do tumor e metástases, a partir da interação com TLR. Outros mediadores endógenos ligantes dos TLR incluem as HSP; que podem promover a progressão do tumor e metástases (6).

A indústria farmacêutica já investiu milhões de dólares em desenvolvimento de novas substâncias, agonistas de TLR, para o tratamento do câncer; sendo que algumas destas se encontram em ensaios clínicos de fase III para câncer de pele e de pulmão $(22,67,69)$.

Entretanto, devido à dualidade na função dos TLR em neoplasias malignas, o conhecimento da atuação dos TLR é fundamental para investimentos futuros na tentativa de modulação da resposta destes receptores em direção à atividade 
antitumoral para tratamento de neoplasias malignas, como o carcinoma epidermóide de boca.

\subsection{Estudo dos TLR em câncer de boca}

\subsubsection{Câncer de boca}

O câncer de boca é a sexta neoplasia maligna mais comum e tem um prognóstico restrito em mais de $50 \%$ dos casos diagnosticados anualmente $(70,71)$. Segundo a estimativa do Instituto Nacional de Câncer (INCA), a incidência do câncer de boca no Brasil será de 14.170 novos casos em 2012, sendo 9.990 homens e 4.180 mulheres. $^{3}$

O câncer de boca é uma denominação que inclui as lesões de lábio e de cavidade oral (mucosa bucal, gengivas, palato duro, língua oral e assoalho da boca), representado principalmente pelo carcinoma epidermóide (CEC). O CEC em lábio é mais frequente em indivíduos leucodermas e com história de exposição crônica aos raios solares ultravioleta, e registra maior ocorrência no lábio inferior. Em outras regiões da boca está relacionado principalmente ao consumo crônico de tabaco e álcool $(71,72)$. Outros fatores, como infecção por papilomavírus humano (HPV), dieta e nutrição, imunossupressão, ingestão de mate, status socioeconômico; podem também estar envolvidos (72).

O padrão-ouro para o diagnóstico definitivo do CEC de boca é o exame histopatológico. Atualmente se almeja a identificação de marcadores moleculares tumorais que proporcionem o diagnóstico precoce e que possam predizer o curso da doença, tendo em vista o prognóstico ainda reservado dos casos de CEC de boca $(73,74)$.

A carcinogênese do CEC de boca envolve, microscopicamente, a transformação do epitélio, que desenvolve hiperplasia, seguindo para epitélio com displasia, carcinoma in situ e, por fim, carcinoma invasivo. As alterações genéticas

\footnotetext{
${ }^{3}$ http://www2.inca.gov.br/wps/wcm/connect/tiposdecancer/site/home+/boca/definicao
} 
observadas no câncer de cabeça e pescoço estão relacionadas principalmente à ativação de oncogenes e inativação de genes supressores de tumor, levando a alterações nos mecanismos de sinalização, envolvendo receptores de crescimento celular, fatores de tradução e transcrição que regulam a resposta aos danos do DNA. A desregulação na duração do ciclo celular e adiamento da morte celular programada (apoptose) ocorrem em frequência suficiente para modificar drasticamente o fenótipo celular, direcionando a progressão da doença (73).

Estas alterações genéticas incluem o aumento da expressão e ativação de oncogenes, tais como: ciclina D1, c-Myc (oncogene homólogo a mielocitomatose viral v-myc), ERBB-2 (oncogene 2 homólogo a leucemia eritroblástica viral v-erb-b2), EGFR (receptor do fator de crescimento epidermal), H-ras (oncogene da proteína transformadora p21); e mutações, deleções e hipermetilação levam a inativação de genes supressores de tumor, como: p16, p53, p21 (75).

Tendo em vista que alterações nos TLR podem estar implicadas no crescimento, progressão e agressividade do tumor; e na imunossupressão que permite o escape do controle imunológico de células malignas numa grande variedade de tumores (20-22); acrescido do fato de que a cavidade bucal está cronicamente exposta a uma variedade de agentes patogênicos, alvos clássicos dos TLR, e por irritantes tóxicos provenientes do tabaco e do álcool, que por sua vez constituem fatores de risco clássicos para o câncer de boca; ou ainda pela inflamação crônica resultante das doenças inflamatórias bucais, como o líquen plano oral (15, 23-27), a relação entre estes receptores e o CEC será abordada nas próximas sessões desta revisão de literatura.

\subsubsection{Expressão gênica e proteica dos TLR em células tumorais de CEC de boca}

Poucos estudos analisam isoladamente a relação dos TLR e o CEC de boca. Muitos deles analisam em conjunto com CEC de outras regiões de cabeça e pescoço; apesar das atuais evidências de diferenças nos fatores relacionados ao seu desenvolvimento e comportamento, como por exemplo, a relação entre o CEC de orofaringe e a infecção por HPV, que além da relação de causa, observa-se também um melhor prognóstico do CEC de orofaringe nos pacientes infectados por 
HPV (76). Desta forma, nesta revisão foram incluídos os artigos científicos relevantes a respeito da investigação do papel dos TLR no CEC de boca e de cabeça e pescoço, publicados até Junho de 2012 por meio de consulta na base de dados PubMed.

O TLR2 apresentou alta expressão proteica em queratinócitos do epitélio displásico de leucoplasias e de CEC de boca, por meio de análise imunoistoquímica (IHQ) de 50 amostras de arquivo (tecidos fixados em formalina e embebidos em parafina) de cada grupo. Os autores deste estudo sugerem que a expressão do TLR2 por queratinócitos de lesões potencialmente malignas e malignas pode estar correlacionada com a resistência à apoptose (77).

A análise por imunofluorescência indireta e IHQ de 20 amostras frescas (secções de tecido congelado) de CEC de laringe revelou aumento da expressão proteica do TLR2, assim como elevados níveis de expressão do TLR3 e TLR4 nas células malignas (78).

Em estudos da expressão dos TLR a partir de culturas celulares foi demonstrada alta expressão gênica, por meio de RT-PCR (transcrição reversa prévia a reação em cadeia da polimerase), e proteica, por meio de Western blot, do TLR2 e TLR3; e baixa expressão do RNAm do TLR4 e TLR9, na avaliação de oito tipos de linhagens de CEC de boca, laringe e seio maxilar (79). Outro estudo observou forte expressão de RNAm dos TLR2, TLR3 e TLR5, enquanto que os TLR1 e TLR4 mal foram detectados em RT-PCR quantitativo em linhagens de CEC de faringe. Em relação à expressão proteica, os TLR2 e TLR5 foram também intensamente marcados por $\mathrm{IHQ}$, enquanto o TLR3 apresentou marcação pouco intensa (80).

A expressão do TLR2 parece estar elevada nas células do CEC de boca e de cabeça e pescoço, e pode ser correlacionada com a inibição da apoptose, embora a análise de linhagem de CEC primário de língua moderadamente diferenciado tenha identificado fraca expressão do TLR2. Além disso, nesta mesma análise, foi verificado que este receptor juntamente com o TLR5, apesar de funcionalmente expressos nesta linhagem celular, não influenciaram na proliferação celular, migração, invasão e angiogênese (81). Contudo, esses fatos devem ser analisados com bastante cuidado, desde que no conjunto desses estudos as diferenças podem estar relacionadas a viés de amostragem, tendo em vista que as fontes de amostra para avaliação da expressão do TLR2 são diferentes. As 
investigações que utilizaram amostras humanas, de arquivo ou frescas, obtiveram altos níveis de expressão do TLR2; o resultado conflitante teve origem em estudos com amostras de culturas celulares, talvez pelos diferentes graus de diferenciação destas linhagens.

Em relação ao TLR3, além dos estudos de Szczepanski et al. (73) e Nomi et al. (74), outras investigações demonstraram também o aumento da expressão do TLR3. A análise de oito diferentes linhagens de culturas celulares de CEC de faringe e de laringe por Western blot encontrou aumento da expressão deste receptor, que também foi observada em aproximadamente $80 \%$ dos tumores analisados e metástases de linfonodos de pacientes com CEC de boca. Os autores desta pesquisa sugerem que o estímulo inicial para a desregulação e estimulação da via do NF-kB em células tumorais do CEC de cabeça e pescoço seja independente do TLR3, mas o aumento da expressão deste receptor colaboraria com a manutenção da ativação desta via de sinalização, e, consequentemente, com o crescimento do tumor (82).

Também foi detectada elevada expressão gênica dos TLR3, TLR4, TLR7 e TLR9 por meio de avaliação por RT-PCR a partir de 20 amostras congeladas de CEC de esôfago. A análise IHQ de 87 amostras de arquivo de CEC de esôfago mostrou diferença estatisticamente significativa na expressão proteica apenas dos TLR3 e TLR7. Além disso, foi possível relacionar significativamente a expressão do TLR3 e a profundidade de invasão da lesão e metástases loco-regionais; e a expressão do TLR7 nas células tumorais foi significativamente associada ao grau de diferenciação destas. E que, apesar da ausência de diferença estatistica em relação à expressão proteica, o TLR4 foi significativamente associado a metástase em linfonodo e o TLR9 foi correlacionado com piora do grau histológico (83).

$\mathrm{E}$, com respeito à expressão do TLR3, uma análise microarray de tecido incluindo 153 amostras de CEC de boca revelou baixa expressão citoplasmática do TLR3 em 80\% das amostras, enquanto as amostras restantes (20\%) apresentaram elevada expressão. Esta alta expressão do TLR3 foi significativamente correlacionada com tumores pouco diferenciados e com casos de invasão perineural, indicando que o TLR3 poderia ser um marcador de prognóstico no CEC de boca. Além disso, a estimulação do TLR3 em culturas de células de CEC de boca com ácido polyinosinic-polycytidylic (poly $\mathrm{I}: \mathrm{C}$ ), um material sintético de cadeia dupla de RNA (dsRNA) agonista do TLR3, ativa a via do NF-kB, levando à produção de IL- 
6 e CCL5, e proporcionando a migração de células tumorais; com consequências na agressividade e invasão deste tumor maligno (19).

Contraditoriamente, outro estudo acerca da estimulação do TLR3 in vitro por poly I:C, resultou em aumento da taxa de apoptose de células tumorais de modo dependente da dose, sugerindo que os agonistas do TLR3 poderiam representar uma nova estratégia para o tratamento do CEC (30). Outra investigação também encontrou níveis elevados de RNAm dos TLR3 e TLR6 em sete linhagens de CEC de nasofaringe, e resultados interessantes sobre a ativação do TLR3 com poly I:C, tal como redução na capacidade de produzir metástases em gânglios linfáticos em experimento com ratos atímicos $(84,85)$.

Os estudos citados encontraram expressão elevada de TLR3 em células malignas do carcinoma de células escamosas, exceto o estudo de Rydberg et al. (2009) que observou baixa expressão proteica do TLR3 numa avaliação de apenas três amostras de carcinoma epidermoide de laringe.

Os resultados contraditórios sobre os efeitos da estimulação in vitro do TLR3 no câncer de boca podem ter sido produzidos pelos diferentes tipos e estágios de diferenciação das linhagens de células malignas incluídas nos diversos estudos. Por exemplo, em linhagens de tumores primários de CEC de boca, a estimulação do TLR3 por poly I:C provoca ativação da via de sinalização NF-kB; e em células metastáticas o efeito era inverso, induzindo a apoptose. Neste estudo, os autores sugeriram que esta diferença na resposta estava relacionada à dessensibilização do TLR3 em células de tumor primário pela exposição a produtos moleculares de microrganismos, presente no microambiente bucal, em oposição ao microambiente estéril dos linfonodos (86).

Em relação ao TLR4, os estudos de Rydberg et al. (75) e Nomi et al. (74) revelaram baixa expressão deste receptor em CEC de laringe, faringe e de boca. $E$ embora o estudo de Szczepanski et al. (73) evidencie expressão positiva do TLR4 em células tumorais, este gene era menos expresso em relação ao TLR2 e TLR3.

Outro estudo também detectou baixo nível de expressão do TLR4 e que este receptor não era funcional em linhagens celulares de CEC de língua moderadamente diferenciado, alteração esta que pode estar relacionada à herança de polimorfismos (81). E um estudo com 78 amostras de arquivo de CEC de laringe evidenciou, por IHQ, moderada expressão do TLR4 em 49\% das amostras e que 
esta expressão não estava significativamente correlacionada com as variáveis clínico-patológicas, como a agressividade do tumor ou sobrevida global (18).

Contraditoriamente, o estudo de linhagens celulares de tumores de CEC de boca e de laringe e de 39 amostras de arquivo dos mesmos tumores, apresentaram elevados níveis de RNAm do TLR4, por RT-PCR, bem como da proteína, por IHQ. Entretanto, níveis elevados de RNAm e de proteína do TLR4, estavam relacionados a linhagens e tumores bem ou moderadamente diferenciados, e pouco expressa em tumores pouco diferenciados, opondo-se aos resultados obervados Bergmann et al. (18), pois foi identificada relação da expressão do TLR4 ao grau de agressividade do tumor. E, finalmente, opondo-se aos resultados de Park et al. (76), o TLR4 estava funcionalmente ativo em células malignas promovendo a proliferação de células tumorais e induzindo resistência à apoptose mediada por drogas, especialmente em linhagens de CEC de laringe (87).

Outro estudo também correlacionou a expressão de moléculas TLR4 com a agressividade do CEC de laringe, por IHQ, em 24 amostras de arquivo. Sugerindo que o TLR4 possa servir futuramente como um biomarcador para a proliferação do tumor e da agressividade (88).

Os outros TLR foram menos explorados no CEC de cabeça e pescoço em geral. A expressão TLR1 foi descrita em apenas um estudo que detectou baixa expressividade deste receptor em linhagens de CEC de faringe (80). O TLR5 geralmente estava fortemente expresso em células tumorais de CEC de carcinoma da faringe (80) e linhagens celulares de CEC de boca (81). E embora tenha sido demonstrado que este receptor encontra-se ativo, pouco se sabe sobre sua interferência com o CEC (81).

Os TLR7 e TLR9 geralmente demonstraram intensa expressão no CEC de boca (81), bem como em linhagens de células de CEC de laringe, tanto gênica quanto proteica, e foi sugerida uma possível relação com o crescimento tumoral (89).

O aumento da expressão do TLR9 também foi observada por meio de IHQ de 60 amostras de arquivo de CEC de boca, correlacionada a um elevado nível de expressão de um marcador de proliferação tumoral, o Ki-67, sugerindo relação com o tamanho do tumor e lesões pouco diferenciadas (90). Assim como na análise IHQ de 85 amostras de arquivo de adenocarcinoma de esôfago, relacionada a lesões avançadas e com baixos índices de sobrevida (91). 
A expressão TLR6, TLR8 e TLR10 não foram investigadas em células de tumores de CEC de cabeça e pescoço, embora o transcrito do TLR8 tenha sido detectado em estudo de linhagens de CEC de nasofaringe, mas sua relação ou função neste tumor não foram identificadas (84).

Além disso, as células do sistema imunológico dos pacientes que apresentam esta neoplasia maligna, tais como linfócitos T NK, células dendríticas e linfócitos polimorfonucleares; apresentam comprometimento em suas funções e baixa capacidade de combate às células malignas. Esta deficiência na função antitumoral destas células pode ser mediada por efeitos imunossupressores dos TLR3, TLR4 e TLR7 (82, 92, 93).

A investigação sobre a função de TLR no desenvolvimento do câncer de boca constitui vasto campo de investigação. Na próxima seção foi realizada a revisão dos estudos de associação dos SNP nos TLR, tema desta investigação.

\subsubsection{Polimorfismos de TLR e câncer bucal}

Existe evidência que alterações na expressão gênica e proteica possam estar relacionadas à herança de SNP (28). No caso do CEC de cabeça e pescoço, os estudos de associação de SNP em TLR são, principalmente, de casos de CEC de nasofaringe.

Quatro SNP do TLR3 (-13909C/T, rs3775291; 13766C/T, sem designação rs (ND); 829A/C, ND; 9948C/T, rs5743312) foram genotipados por sequenciamento em população chinesa com carcinoma da nasofaringe. O alelo C do SNP 829A/C, presente em região não codificante do gene (íntron 1) revelou risco aumentado do desenvolvimento de CEC de nasofaringe na população do estudo (OR = 1.49, IC $95 \%=1.10-2.00, p=00068)$. Quando a análise foi ajustada para idade, sexo e titulação de anticorpos ao antígeno do capsídeo viral (VCA)-IgA (detecção da infecção atual ou recente com o vírus Epstein-Barr (EBV), que por sua vez pode estar relacionado com esta neoplasia), o risco de desenvolvimento de lesão maligna foi significativamente menor nos indivíduos que apresentavam o haplótipo "ATCT" $(\mathrm{OR}=0.028, \mathrm{IC} 95 \%=002-0.341, p=0.0054)$, em comparação com o haplótipo mais comum "ACCT" (94). 
A genotipagem de dois SNP em região codificante do TLR4 pela reação em cadeia da polimerase associada à avaliação de polimorfismo de fragmento de restrição (PCR-RFLP), por meio do uso de enzimas de resticção para avaliação dos SNP Asp299Gly-rs4986790 e Thr399lle-rs498679, revelou associação significativa entre o SNP rs4986790 e as altas taxas de recorrência do CEC de boca e reduzida taxa de sobrevida livre de doença $(p=0,04)$. O outro SNP rs498679 apresentou também semelhante relação às taxas de recorrência e sobrevida $(p=0,0006)$. Além disso, os pacientes com CEC de boca tratados com cirurgia e terapia sistêmica adjuvante (radio e quimioterapia) que apresentavam o genótipo selvagem do SNP rs4986790 apresentaram longo período de sobrevida livre de doença, relacionando assim este genótipo ao sucesso da terapia antitumoral (18).

Outro estudo também avaliou os SNP do TLR4 acima citados (D299G, rs4986790; T399I, rs498679) e um SNP de TLR2 (R753Q) por meio de PCR-RFLP e as diferenças na frequência dos genótipos do SNP TLR4-rs4986790 foram estatisticamente significativas entre casos e controles $(p=0,007)$. Além disso a presença do alelo mutante $\mathrm{T}$ foi associada a maior risco de desenvolvimento de câncer de nasofaringe $(\mathrm{OR}=1.853,95 \% \mathrm{Cl}=1.184-2.961, p=0.007)$ e ao aumento na expressão gênica de IL-1A, TFN-a e IL-10 (95).

O SNP 11350G/C (ND) na região não codificante 3'-UTR do TLR4 foi genotipado por sequenciamento e significativamente associado ao câncer de nasofaringe em população chinesa (OR $=2.21$, IC95\% $=1.34-3.64)$, enquanto outro SNP nesta região 11449C/T (ND) não foi correlaciondo ao desenvolvimento desta lesão maligna, mesmo na análise de haplótipos, sugerindo que a variante $11350 \mathrm{C}$ na região 3'-UTR do TLR4 possa atuar como um fator de redução da estabilidade do RNAm $(96,97)$.

Outro estudo investigou sete SNP do TLR10 (rs10856837, rs11466651, rs11466652, rs11466653, rs11096956, rs11096955, rs11466655) em população chinesa, por sequenciamento, porém sem relação estatisticamente significativa; presente apenas na associação do haplótipo GCGTGGC em homens e a predisposição ao câncer de nasofaringe (OR=1.415, IC95\%=1.02-1.94, $p=0.005)$, ajustando sexo, idade, e os títulos de anticorpos VCA-lgA. Esta associação pode indicar que este haplótipo modifica a resposta imune ao Epstein-Barr vírus e, portanto, aumenta o risco individual para o cancro da nasofaringe (98). 
A investigação de SNP em CEC de cabeça e pescoço, especialmente em CEC de boca, é ainda incipiente; visto que a maioria dos estudos investigam a associação destes com CEC de nasofaringe. A investigação em outros TLR se faz necessária para a melhor compreensão da atuação destes receptores nesta neoplasia maligna. 


\section{PROPOSIÇÃO}

Identificar polimorfismos presentes nos genes de receptores Toll-like em população com diagnóstico de líquen plano oral e indivíduos com diagnóstico de carcinoma epidermóide de boca e de cabeça e pescoço (laringe), comparando-os a indivíduos controles sadios, buscando identificar diferenças entre esses grupos de pacientes, sugerindo a relação de risco para o desenvolvimento dos agravos analisados e contribuir com o conhecimento acerca dos aspectos relacionados à etiopatogenia destas doenças. 


\section{CASUÍSTICA - MATERIAL E MÉTODOS}

\subsection{Amostras biológicas e dados dos pacientes}

As amostras biológicas de DNA para o estudo dos polimorfismos de nucleotídeo único (SNP) foram selecionadas a partir de amostras de material genético previamente coletado de pacientes portadores de líquen plano oral (LPO, $n=175)$, carcinoma epidermóide (CEC) de boca $(n=40)$ e de laringe $(n=35)$, e controles saudáveis $(n=89$ ), coletados no período de novembro de 2009 a maio de 2011 na Unidade de Medicina Oral e Patologia Oral e Maxilofacial da Faculdade de Medicina e Odontologia da Universidade do País Basco (UPV/EHU).

Estas amostras de DNA, extraído das células da mucosa bucal que haviam sido coletadas por meio de bochecho com solução de clorexedina, se encontravam armazenadas em freezer a - $20^{\circ} \mathrm{C}$ no banco de amostras biológicas, de acordo com resolução ética local, do Laboratório do Banco de DNA no Centro de Investigación Lascaray da Universidade do País Basco (UPV/EHU), sob a responsabilidade da Profa. Dra. Marian Martinez de Pancorbo.

Os experimentos foram realizados com a colaboração de Xabier MarichalarMendia, Natalia Rey-Barja e Amelia Acha-Sagredo, alunos de pós-graduação da Universidade do País Basco (UPV/EHU), sob a responsabilidade do Prof. Dr. José Manuel Aguirre-Urizar, que permitiu a colaboração para o desenvolvimento deste estudo por meio do Programa de Doutorado com Estágio no Exterior (PDEE) oferecido pela Coordenação de Aperfeiçoamento de Pessoal de Nível Superior (CAPES), processo 0305-11-1(ANEXO A). A genotipagem por ensaio TaqMan ${ }^{\circledR}$ foi realizada no Laboratório de Genética da Faculdade de Medicina e Odontologia da Universidade do País Basco (UPV/EHU), sob a responsabilidade do Prof. Dr. José Manuel Aguirre-Urizar e o pirosequenciamento foi realizado no Laboratório do Banco de DNA no Centro de Investigación Lascaray da Universidade do País Basco (UPV/EHU), sob a responsabilidade da Profa. Dra. Marian Martinez de Pancorbo.

Este trabalho também foi autorizado pelo Comitê de Ética em Pesquisa da Faculdade de Odontologia da Universidade de São Paulo (FOUSP), parecer 47811/2012 (ANEXO B). 


\subsection{Desenho do estudo}

Para o estudo dos SNP em genes de receptores Toll-like (TLR) foi conduzido um estudo do tipo caso-controle pareado. Neste tipo de desenho de estudo epidemiológico observacional e retrospectivo; cada grupo de casos (pacientes portadores de LPO, CEC de boca e CEC de laringe) foi comparado, isoladamente, quanto à exposição ao fator de risco estudado (herança de polimorfismos genéticos nos TLR), ao grupo controle que não apresenta a doença e é composto por indivíduos semelhantes aos do grupo de casos (pareamento por idade).

Para a inclusão dos indivíduos em cada grupo de amostra (LPO, CEC de boca, CEC de laringe) foi adotado o diagnóstico histopatológico como critério de inclusão, de acordo com os princípios da Organização Mundial da Saúde (OMS) (99, 100). Os casos incluídos foram avaliados microscopicamente por um único patologista, no caso o Prof. Dr. Jose Manuel Aguirre Urizar (UPV/EHU). Os indivíduos do grupo controle foram selecionados entre os pacientes que procuraram ou estavam em tratamento odontológico por outras especialidades e não apresentavam sinais clínicos de qualquer lesão bucal, nem histórico de qualquer tipo de neoplasia maligna atual ou já tratada.

A coleta das amostras para a obtenção de material genético dos pacientes incluídos foi realizada pela coleta de células da mucosa bucal por meio de bochecho com solução aquosa de clorexedina. O enxágue era realizado minimamente uma hora após a última refeição ou higiene bucal, durante um período de dois minutos. $\mathrm{O}$ material resultante foi coletado em tubos de fundo cônico de $50 \mathrm{~mL}$ (tipo Falcon, TPP Techno Plastic Products - Trasadingen, Suíça) e submetido à centrifugação a 1200 rpm por 15 minutos a $4^{\circ} \mathrm{C}$ (centrífuga Eppendorf $5810 \mathrm{R}$ - Hamburg, Alemanha), num período médio de até 2 horas após a coleta. Após a centrifugação, o sobrenadante foi descartado e $1 \mathrm{~mL}$ da solução de lise celular $\left(\right.$ QIAGEN $^{\circledR}$ Duesseldorf, Alemanha) foi acrescido ao precipitado (pellet), que por sua vez foi agitado até sua completa homogeneização. Esta mistura foi armazenada em temperatura ambiente $\left(15-25^{\circ} \mathrm{C}\right)$ até a execução dos passos seguintes para a extração do DNA. 
A extração de DNA foi realizada a partir do protocolo Gentra Puragene para células bucais coletadas por meio de enxágues da QIAGEN $^{\circledR}$, de acordo com as recomendações do fabricante, e o material genético obtido foi congelado em freezer a $-20^{\circ} \mathrm{C}$ (ANEXO C). A qualidade do DNA extraído foi avaliada por gel de agarose $1 \%$ e a pureza por espectrofotometria (NanoDrop 2000, Thermo Fisher Scientific Inc. - Massachusetts, EUA) por meio da avaliação da relação entre as absorbâncias A260/A280 para avaliação da contaminação por proteínas, e A260/A230 para avaliação da contaminação por sais oriundos dos reagentes da extração de DNA; sendo ambas as relações consideradas adequadas entre 1,8 e 2,0.

\subsection{Seleção dos polimorfismos genéticos de um único nucleotídeo nos genes dos TLR}

Os SNP nos genes dos TLR foram selecionados para genotipagem de acordo com a revisão da literatura realizada e a análise destes por meio do banco de dados Genome Variation Server oferecido pelo Programa Seattle de SNP para Aplicação Genômica, ${ }^{4}$ uma ferramenta para acesso rápido aos dados de genótipos humanos de SNP provenientes de diversas bases de dados.

Desta forma, para os genes dos TLR1, TLR2, TLR4, TLR6, TLR9 e TLR10 foram selecionados os SNP relacionados na Tabela 4.1 dentre os resultados provenientes do referido banco de dados correlacionando-se diferentes fontes dados de avaliação populacional dos SNP (GenBank NCBI, HapMap, IIPGA, Perlegen) ${ }^{5}$ em caucasianas, considerando as seguintes características:

Menor frequência alélica (MAF) > 10\%: esta variável está diretamente relacionada ao tamanho da amostra e, consequentemente, ao poder do estudo. Embora, originalmente, polimorfismo comum tenha sido definido como aquele que tivesse frequência de $1 \%$ na população, na prática, os estudos de caso-controle de associação incluem SNP com MAF mais elevada. Inclusive grandes investigações como o Projeto Internacional HapMap, projetado para

\footnotetext{
${ }^{4}$ http://gvs.gs.washington.edu/GVS/index.jsp http://pga.gs.washington.edu/
} 
melhorar a eficiência desse tipo de estudo, foram intencionalmente dirigidas a SNP com MAF superiores a $5 \%$. Isto porque, no planejamento desse tipo de estudo, é necessário determinar o número de amostras a serem coletadas de forma a alcançar um poder suficiente para detectar a hipótese investigada. A falta de atenção a estes aspectos possibilita falhas na detecção de diferenças significativas (por exemplo, erro tipo II) ou coleta excessiva e desnecessária de amostras. Em ambos os casos princípios éticos e de boas práticas clínicas são transgredidos (101).

$>$ Desequilíbrio de ligação entre os SNP selecionados (LD) < 0,65: genótipos de SNP que estão próximos (< $10 \mathrm{~kb}$ ) tendem a estar correlacionados, ou seja, o indivíduo apresenta o mesmo genótipo para os SNP contidos nesta região, os chamados tagSNP. Isto permite uma análise indireta de alguns SNP, uma vez que não seria necessário realizar a genotipagem de todos os SNP de um mesmo tagSNP, pois com a genotipagem direta de alguns, os outros podem ser presumidos indiretamente. Esta correlação depende do valor atribuído ao LD, quando é igual a 1 (ou 100\%), implicaria numa correlação perfeita. Estes dados estão disponibilizados em bases de dados como o Programa Seattle de SNP para Aplicação Genômica (102). Desta forma, os SNP selecionados para investigação direta não deveriam apresentar altos valores de LD.

Posição e tipo de SNP: quando em região codificante, foram selecionados aqueles que proporcionavam alteração da seqüência de aminoácidos da proteína final; ou, quando em região não-codificante, foram selecionados aqueles que influenciam o splicing alternativo e, assim, produzem um RNAm diferente do normal, e consequentemente, uma proteína alterada; ou aqueles próximos à região promotora do gene e que potencialmente influenciam sua expressão gênica $(103,104)$.

\footnotetext{
${ }^{5}$ GenBank: NIH genetic sequence database; HapMap: International Haplotype Map Project; IIPGA: bases de
} dados IIPGA-WEISS-MARTINEZ; Pelergen: base de dados do laboratório Perlegen Sciences Inc. 
Tabela 4.1 - Dados dos SNP nos genes-alvo selecionados para genotipagem nos grupos caso (LPO, CEC de boca e CEC de laringe) e grupo controle, com base nos critérios de seleção dos SNP adotados para este estudo (posição do SNP, MAF e LD), a partir de SNP encontrados na revisão da literatura relacionada e na consulta a bancos de dados

\begin{tabular}{ccccc}
\hline Gene & dbSNP & posição do SNP & alelos & MAF \\
\hline TLR1 & rs4833095 & codificante: missense & $\mathrm{C} / \mathrm{T}$ & 0.47 \\
TLR1 & rs5743618 & codificante: missense & $\mathrm{G} / \mathrm{T}$ & 0.24 \\
TLR2 & rs4696480 & não codificante: íntron & $\mathrm{A} / \mathrm{T}$ & 0.48 \\
TLR4 & rs1927911 & não codificante: íntron & $\mathrm{A} / \mathrm{G}$ & 0.37 \\
TLR6 & rs5743810 & codificante: missense & $\mathrm{A} / \mathrm{G}$ & 0.28 \\
TLR9 & rs5743836 & não codificante: próx. extrem. 5, & $\mathrm{C} / \mathrm{T} / \mathrm{A} / \mathrm{G}$ & 0.15 \\
TLR9 & rs352139 & não codificante: íntron & $\mathrm{C} / \mathrm{T}$ & 0.46 \\
TLR10 & rs11096957 & codificante: missense & $\mathrm{A} / \mathrm{C}$ & 0.49 \\
\hline
\end{tabular}

missense: mutação por substituição de base nitrogenada, resultando um aminoácido diferente na proteína codificada

\subsection{Genotipagem}

\subsubsection{Por ensaio TaqMan ${ }^{\circledR}$}

A genotipagem da maior parte dos SNP (exceto SNP TLR1-rs5743618 e TLR9-rs5743836) selecionados para este estudo foi realizada por meio da amplificação pela reação da polimerase em cadeia em tempo real (qPCR), utilizando-se o equipamento Bio-Rad iCycler iQ5 PCR Thermal Cycler (Bio-Rad ${ }^{\circledR}$ Laboratories Inc. - Califórnia, EUA) e ensaios TaqMan ${ }^{\circledR}$ para genotipagem (Applied Biosystems - Califórnia, EUA), com as sequências dos iniciadores e sondas estabelecidas pelo fabricante, funcionalmente testadas, e disponíveis para os SNP avaliados por este método.

Neste sistema, além dos iniciadores (primers) que amplificam somente a região de interesse, ou seja, aquela que contém o SNP; são utilizadas duas sondas para discriminação dos alelos (alelo selvagem e alelo mutado) marcadas com diferentes fluoróforos $\left(\mathrm{VIC}^{\circledR}\right.$ e $\left.F A M^{\circledR}\right)$ que hibridizam seletivamente e especificamente 
cada um dos alelos, e a proporção de indivíduos heterozigotos e homozigotos para cada genótipo é estimada por meio da leitura de diferentes fluorescências emitidas a partir da hibridização das sondas pelo equipamento de qPCR (Figura 4.1).

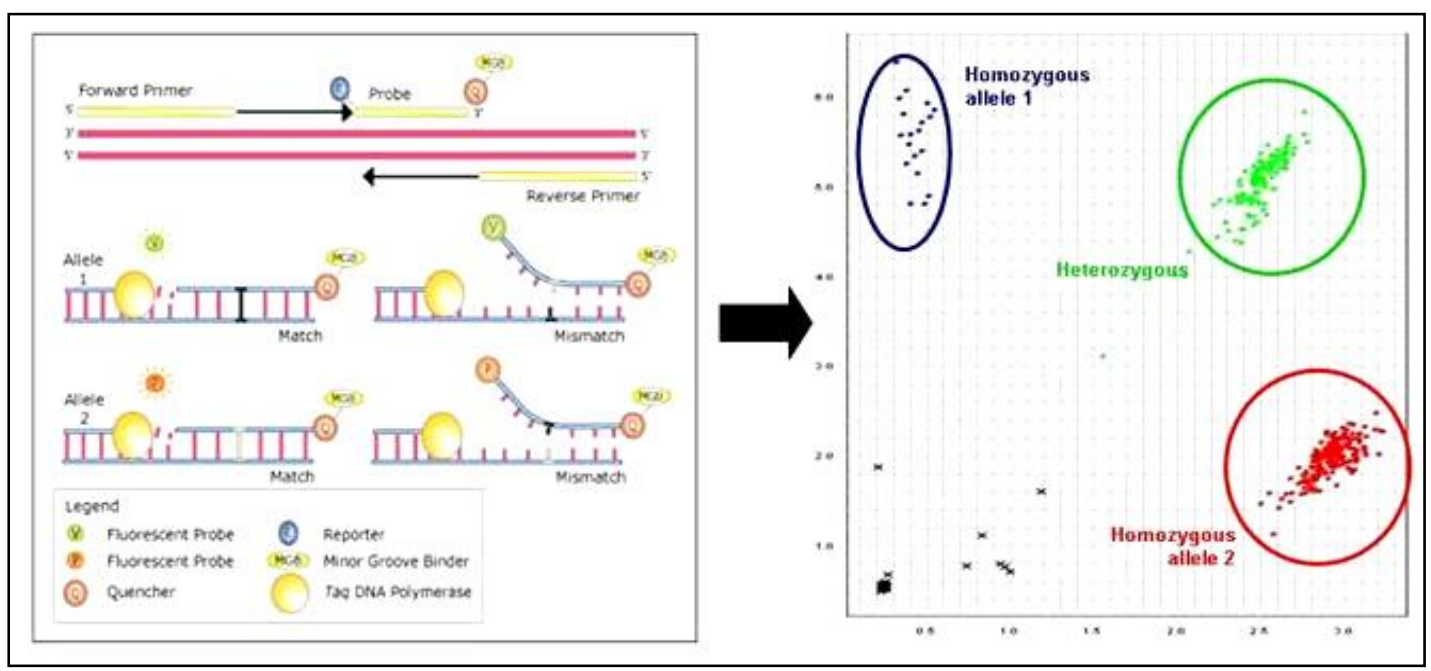

Figura 4.1 - llustração do ensaio $\operatorname{Taqman}^{\circledR}$ para genotipagem. À esquerda observa-se que estes ensaios utilizam, além dos dois iniciadores (forward primer e reverse primer), sondas específicas para cada um dos alelos marcadas com diferentes agentes flouróforos $\left(V_{I C}{ }^{\circledR}\right.$ e $\left.F A M^{\circledR}\right)$, que permitem a identificação dos alelos de forma precisa. À direita observam-se os resultados de genotipagem de um ensaio representados graficamente, sendo que cada ponto representa uma amostra. A cor e posição no gráfico indica o genótipo de cada amostra: azul - homozigotos para o alelo 1 (geralmente os marcados por $\mathrm{FAM}^{\circledR}$, verde - heterozigóticos (marcados pelos dois fluoróforos) e vermelha homozigotos para o alelo 2 (geralmente marcado por $\mathrm{VIC}^{\circledR}$ ) e os pontos restantes representam os controles negativos e as amostras que não foram adequadamente amplificadas

Fonte: http://medicine.tcd.ie/neuropsychiatric-genetics/functional-genetics-genomics/genotyping.php

Contudo, previamente à genotipagem de todas as amostras incluídas no estudo, a validade dos ensaios $\operatorname{TaqMan}^{\circledR}$ para genotipagem foi verificada por amplificação pela reação da polimerase em cadeia convencional (PCR) e sequenciamento de amostras de DNA-teste amplificadas (quatro amostras de DNA de alta qualidade que não faziam parte das amostras em estudo, Bioline Reagents Ltd. - Londres, Reino Unido), comparando-se os resultados obtidos pelo sequenciamento destas amostras amplificadas com os resultados obtidos por meio da genotipagem com os ensaios $\operatorname{TaqMan}^{\circledR}$ das mesmas amostras.

Para tal foram desenhados iniciadores para os SNP dos TLR que foram analisados por ensaios $\operatorname{TaqMan}^{\circledR}$ para genotipagem (Tabela 4.2) para a PCR, por meio do uso do programa PerlPrimer $v 1.1 .20^{6}$, levando em consideração a

\footnotetext{
${ }^{6}$ Marshall OJ. PerlPrimer: cross-platform, graphical primer design for standard, bisulphite and real-time PCR. Bioinformatics 2004;20(15):2471-2.
} 
temperatura de associação dos iniciadores, entre $5^{\circ} \mathrm{O}$ e $64^{\circ} \mathrm{C}$, com uma diferença máxima de $3^{\circ} \mathrm{C}$ entre os iniciadores senso e anti-senso; o tamanho dos iniciadores, entre 20 e 24 pares de bases; a porcentagem de bases GC, entre 40-60\%; a ausência de formação de estruturas secundárias, características estas que conferem melhor desempenho e resultado da reação de PCR; e, por fim, a confirmação da provável amplificação do produto correto pela consulta à ferramenta Basic Local Alignment Search Tool (BLAST) ${ }^{7}$, que compara a sequência fornecida (iniciadores desenhados) a uma base de dados de sequências e identifica aquelas que se assemelham à sequência consultada dentro do genoma da espécie humana e de outras espécies, evitando a amplificação de outras áreas do genoma ou de material genético de outra espécie que pode por ventura constituir contaminação.

Tabela 4.2 - Sequência dos iniciadores para amplificação da região que contém o SNP de interesse, utilizados na reação de PCR convencional de amostras de DNA-teste, cujos produtos da amplificação foram sequenciados para a validação dos ensaios TaqMan para genotipagem selecionados para tais SNP em TLR

\begin{tabular}{ccc}
\hline Gene-SNP & Iniciadores 5' $\rightarrow$ 3' & $\begin{array}{c}\text { Tamanho do } \\
\text { produto de PCR }\end{array}$ \\
\hline TLR1-rs4833095 & $\begin{array}{c}\text { Senso: TTGGATGTGTCAGTCAAGAC } \\
\text { Anti-senso: TACCATACAGTTGTATGCCA }\end{array}$ & $209 \mathrm{pb}$ \\
\hline TLR2-rs4696480 & $\begin{array}{c}\text { Senso: AAGTACATAGTTGTCACAGTCC } \\
\text { Anti-senso: CAAGGGAGCAGTTTATTGTG }\end{array}$ & $240 \mathrm{pb}$ \\
\hline TLR4-rs1927911 & $\begin{array}{c}\text { Senso: TTAGGCTTACAAAGAATGTGGG } \\
\text { Anti-senso: TGTCTGGCAGTCAAGATGTC }\end{array}$ & $232 \mathrm{pb}$ \\
\hline TLR6-rs5743810 & $\begin{array}{c}\text { Senso: ACCCAACTAGTTATTCGCT } \\
\text { Anti-senso: TTGAGATATTCCACAGGTTTGG }\end{array}$ & $235 \mathrm{pb}$ \\
\hline TLR9-rs352139 & $\begin{array}{c}\text { Senso: GAGACTGAGTTCAGGTTCCC } \\
\text { Anti-senso: GGTTGGAGGACAAGGAAAGG }\end{array}$ & $400 \mathrm{pb}$ \\
\hline TLR10-rs11096957 & $\begin{array}{c}\text { Senso: ACCAATGGACACAAATTCTGG } \\
\text { Anti-senso: GTCAAGATAAGCCTTACCACC }\end{array}$ & $274 \mathrm{pb}$ \\
\hline
\end{tabular}

*pb: pares de bases

As reações de PCR foram realizadas acrescentando-se a cada microtubo de $0.2 \mathrm{~mL}$ contendo $20 \mathrm{ng}$ da amostra de DNA-teste, um mix de soluções de dNTP Mix (0.2 mM), tampão de reação $\left(\mathrm{NH}_{4}\right.$ Buffer $\left.1 \mathrm{x}\right)$, albumina de soro bovino (BSA; 0.5 $\mathrm{mg} / \mathrm{mL})$, magnésio, iniciadores e enzima BioTAQ ${ }^{\circledR}$ DNA Polymerase $(0.5 \mathrm{U} / \mu \mathrm{L})$ num volume final de $25 \mu \mathrm{L}$, de acordo com as condições restantes para cada iniciador (magnésio e iniciadores) descritas na Tabela 4.3 e as recomendações do fabricante (Bioline Reagents Ltd. - Londres, Reino Unido).

\footnotetext{
${ }^{7}$ http://www. http://blast.ncbi.nlm.nih.gov/Blast.cgi
} 
Tabela 4.3 - Resumo das condições para a reação de PCR convencional de amostras de DNAteste com os iniciadores desenhados para a validação dos ensaios TaqMan ${ }^{\circledR}$ para genotipagem selecionados para tais SNP

\begin{tabular}{ccccc}
\hline Gene & {$[\mathrm{Mg}]$} & [iniciador] & TA & [formamida] \\
\hline TLR1-rs4833095 & $2 \mathrm{mM}$ & $150 \mathrm{nM}$ & $61^{\circ} \mathrm{C}$ & - \\
TLR2-rs4696480 & $1.5 \mathrm{mM}$ & $150 \mathrm{nM}$ & $60^{\circ} \mathrm{C}$ & - \\
TLR4-rs1927911 & $2 \mathrm{mM}$ & $100 \mathrm{nM}$ & $61^{\circ} \mathrm{C}$ & - \\
TLR6-rs5743810 & $1.5 \mathrm{mM}$ & $150 \mathrm{nM}$ & $60^{\circ} \mathrm{C}$ & - \\
TLR9-rs352139 & $1.5 \mathrm{mM}$ & $100 \mathrm{nM}$ & $60-61^{\circ} \mathrm{C}$ & $1 \%$ \\
TLR10-rs11096957 & $2 \mathrm{mM}$ & $100 \mathrm{nM}$ & $62^{\circ} \mathrm{C}$ & - \\
\hline
\end{tabular}

[Mg]: concentração de magnésio, [iniciador]: concentração do iniciador, TA: temperatura de associação do iniciador a amostra de DNA, [formamida]: concentração da solução de formamida utilizada na reação com o iniciador desenhado para o SNP do TLR9 [DNA]

As reações preparadas foram submetidas à termociclagem no equipamento

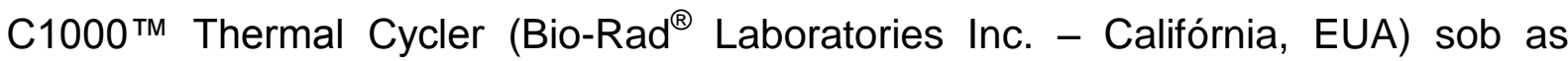
seguintes condições de ciclagem: 4 minutos a 95ํㅡ (desnaturação inicial do DNA), seguidos de 35 ciclos de 30 segundos a 95ํㅡ (desnaturação do DNA), 30 segundos a $60-62^{\circ} \mathrm{C}$ (temperatura de associação variável de acordo com cada iniciador), 30 segundos a $72^{\circ} \mathrm{C}$ (extensão do produto de $\mathrm{PCR}$ ); finalizando com 7 minutos a $72^{\circ} \mathrm{C}$ (extensão final dos produtos da PCR).

A qualidade da reação foi verificada em gel de agarose $1.5 \%$, sendo considerada adequada quando observada uma banda intensa e única do produto de PCR, levando-se em consideração a posição do produto em relação ao marcador de

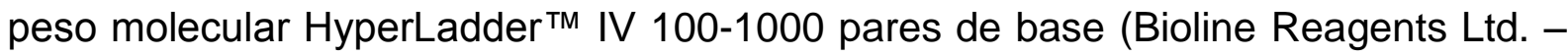
Londres, Reino Unido). Os amplificados considerados adequados foram enviados para sequenciamento no Banco de DNA do Serviço Geral de Genômica e Proteômica da UPV/EHU e os dados do sequenciamento foram comparados aos resultados obtidos pela genotipagem destas amostras de DNA-teste pelos ensaios TaqMan $^{\circledR}$ selecionados para este estudo. Todos os ensaios foram validados e genotiparam as amostras de acordo com os dados do GenBank (APÊNDICE A).

Desta forma as amostras incluídas no projeto foram genotipadas utilizandose os ensaios $\operatorname{TaqMan}^{\circledR}$ selecionados, funcionalmente testados pelo fabricante e validados em laboratório. Foram utilizadas placas ópticas de 96 poços (Hard-Shell ${ }^{\circledR}$ 


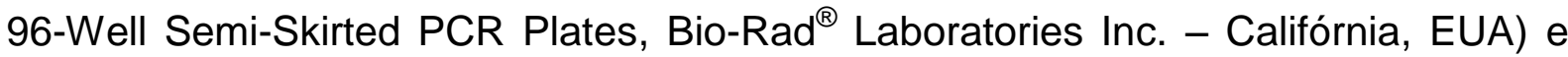
filmes para selamento (Microseal ${ }^{\circledR}$ 'B' Adhesive Seals, Bio-Rad ${ }^{\circledR}$ Laboratories Inc. Califórnia, EUA) padronizados para a reação de qPCR no termociclador Bio-Rad

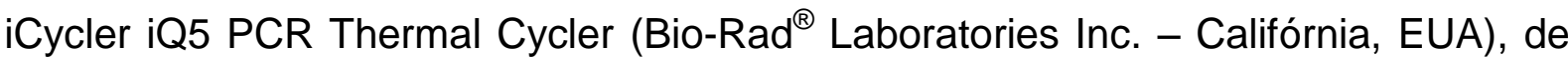
acordo com as recomendações do fabricante para melhor eficiência dos ensaios TaqMan ${ }^{\circledR}$ para genotipagem: a cada $20 \mathrm{ng}$ de DNA, foi acrescentado $0.25 \mu \mathrm{L}$ de $20 \mathrm{X}$ TaqMan $^{\circledR}$ SNP Genotyping Assay (contendo os iniciadores e as sondas marcadas, Applied Biosystems - Califórnia, EUA) e $2.5 \mu \mathrm{L}$ do mastermix Premix Ex Taq ${ }^{\mathrm{TM}}$ Perfect Real Time (Takara Bio Inc. - Kyoto, Japão), num volume final de $5 \mu \mathrm{L}$.

As condições de ciclagem consistiram em: 30 segundos a $95^{\circ} \mathrm{C}$, seguidos de 50 ciclos de 15 segundos a $92^{\circ} \mathrm{C}$ (desnaturação do DNA) e 60 segundos a $60^{\circ} \mathrm{C}$ (associação/extensão-detecção). Os resultados captados foram analisados pelo

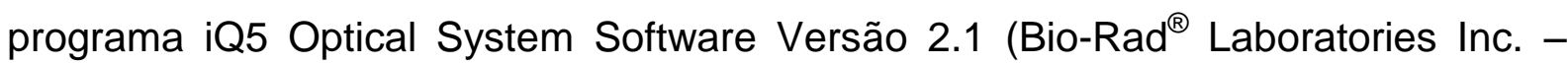
Califórnia, EUA).

\subsubsection{Por pirosequenciamento}

O pirosequenciamento consiste num método não eletroforético para sequenciamento do DNA baseado no "sequenciamento por síntese", onde a cascata enzimática se inicia com a liberação de uma molécula de pirofosfato (PPi), como resultado da incorporação de um nucleotídeo pela DNA polimerase à fita-simples de DNA da amostra. O PPi, por sua vez, é convertido em ATP pela enzima ATP sulfurilase. Esta molécula de ATP fornece energia para a enzima luciferase oxidar a luciferina (molécula bioluminescente presente em algumas plantas e animais) e gerar a luz que é detectada pelo equipamento, capacitando-o a gerar uma curva no gráfico de pirosequenciamento de acordo com a intensidade da emissão de luz, indicando a incorporação de um ou mais nucleotídeos idênticos sequencialmente. Os nucleotídeos não incorporados são degradados pela enzima apirase, previamente à adição do próximo nucleotídeo. Uma vez que a sequência de nucleotídeos acrescentados é conhecida, a sequência da amostra em questão pode ser determinada pela análise do gráfico de pirosequenciamento ou pirograma (105, 106). 
A reação de pirosequenciamento acontece a partir da adição de nucleotídeos a uma fita-simples de DNA da amostra como DNA molde. Para tal, o pirosequenciamento não utiliza o DNA genômico como amostra, mas sim o produto purificado de uma reação de PCR convencional amplificando a região de interesse das amostras de DNA genômico. Porém, com a utilização de um dos iniciadores, senso ou anti-senso, biotinilado; e além do par convencional de iniciadores, é confeccionado também o iniciador de sequenciamento, oposto ao biotinilado (se o iniciador senso é biotinilado, há dois iniciadores anti-senso: um para a amplificação inicial por PCR e outro para sequenciamento; e vice e versa). A presença da biotina em um dos iniciadores confere a possibilidade de separação da fita-dupla do DNA procedente da primeira reação de PCR e sustentação desta fita-simples pela interação da biotina incorporada ao DNA molde à estreptavidina presente em um suporte sólido, tais como esferas de Sepharose ${ }^{\circledR}$ (polímero) ou magnéticas, durante as etapas de purificação do DNA molde (eliminação de restos de reagentes da PCR anterior) para a posterior reação de pirosequenciamento descrita anteriormente (Figura 4.2) (105, 106).

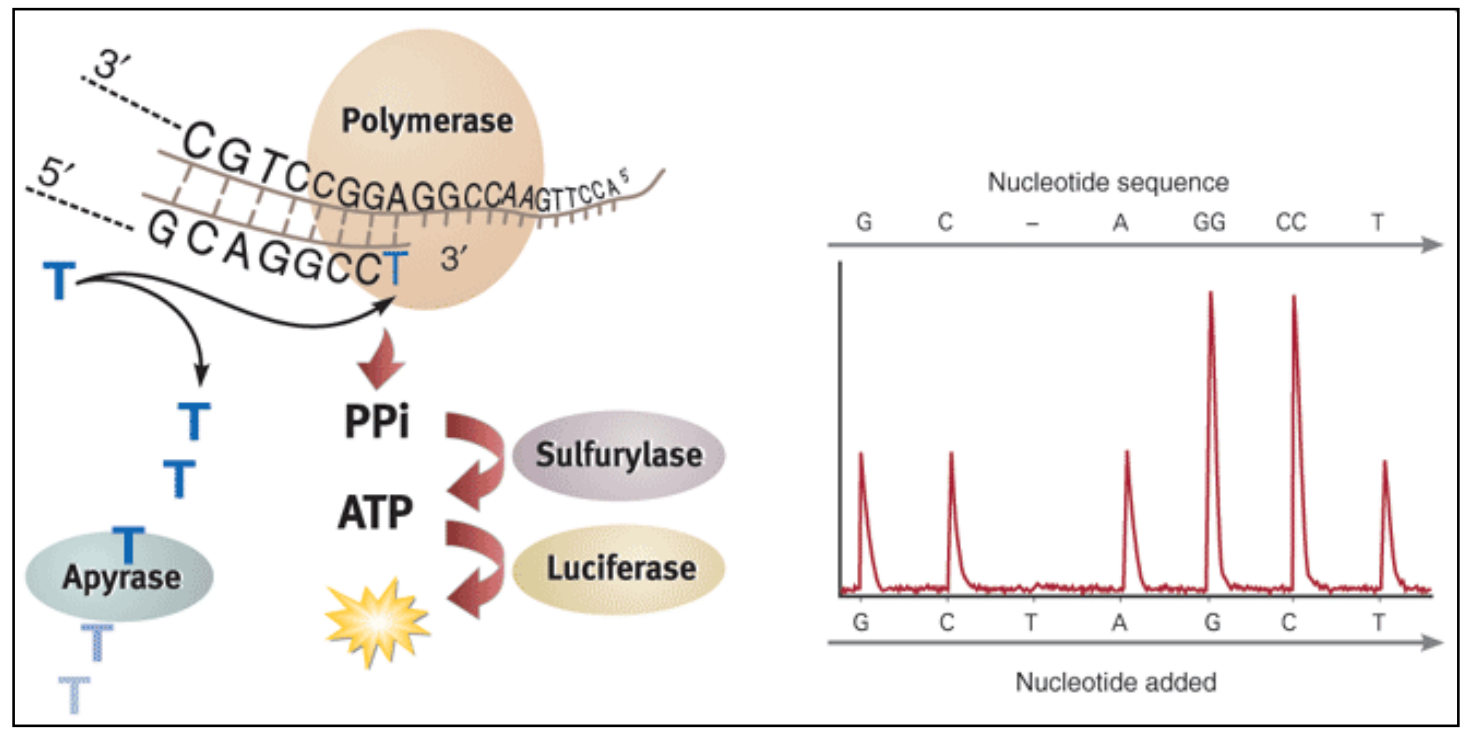

Figura 4.2 - Ilustração do processo de pirosequenciamento. Na imagem da esquerda observam-se as reações enzimáticas subsequentes a uma incorporação bem sucedida de um nucleotídeo ao molde de DNA fita-simples utilizado nesta técnica. Resumidamente, uma molécula de pirofosfato (PPi) é liberada após esta incorporação de nucleotídeo pela DNA polimerase e convertido em ATP pela sulfurilase; o ATP fornece energia para a luciferase induzir a emissão de luz pela luciferina. Esta emissão é registrada pelo equipamento em um gráfico, o pirograma. A direta observa-se o pirograma, em que as alturas dos picos do gráfico são proporcionais ao número de nucleotídeos indenticos incorporados ao molde de DNA 
A genotipagem dos SNP TLR1-rs5743618 e TLR9-rs5743836 foi realizada a partir da técnica de pirosequenciamento. A genotipagem pela metodologia de qPCR com sondas (ensaios $\operatorname{TaqMan}^{\circledR}$ para genotipagem) não é possível para estes SNP. No caso do TLR1-rs5743618, por este SNP estar em uma região que apresenta extensa homologia com o TLR6, tanto os iniciadores quanto a sonda poderiam hibridizar-se à região homóloga do TLR6, tanto quanto ao gene de interesse, TLR1, levando a falsos resultados.

Desta forma, no caso do SNP TLR1-rs5743618, foi realizada uma nestedPCR, amplificando numa primeira reação de PCR convencional uma região do TLR1 não homóloga ao TLR6, porém que a continha em seu interior juntamente com o SNP em questão. Este conjunto de iniciadores foi desenhado no programa PerlPrimer v1.1.20, levando-se em consideração as mesmas características que conferem melhor desempenho e resultado da reação de PCR descritas anteriormente. Uma segunda reação de PCR foi realizada, com o iniciador antisenso biotinilado, para a síntese do DNA molde para o pirosequenciamento. $O$ conjunto de iniciadores senso, anti-senso biotinilado e de sequenciamento foram desenhados no programa PyroMark Assay Design SW 2.0 (QIAGEN $^{\circledR}$ - Duesseldorf, Alemanha) e sintetizados pela Operon (Eurofins MWG Operon - Alabama, EUA). As sequências e características destes iniciadores e dos anteriormente citados estão sumarizadas na Tabela 4.4.

Em relação ao SNP TLR9-rs5743836, a discriminação alélica com metodologia de qPCR com sondas, oferecida pela Applied Biosystems, é possível quando o SNP é do tipo bi-alélico (substituição de um nucleotídeo por um outro, gerando dois possíveis alelos); entretanto, este SNP é tetra-alélico, ou seja, o nucleotídeo mutado pode ser substituído por qualquer um dos outros três existentes, gerando quatro possíveis alelos, como descrito na Tabela 4.1. Neste caso foi desenhado um conjunto de iniciadores senso biotinilado, anti-senso e de sequenciamento, também no programa PyroMark Assay Design SW $2.0\left(\right.$ QIAGEN $^{\circledR}$ Duesseldorf, Alemanha) e sintetizados pela Operon (Eurofins MWG Operon Alabama, EUA). A sequência dos iniciadores citados está sumarizada na Tabela 4.4. 
Tabela 4.4 - Sequência dos iniciadores para amplificação da região que contém o SNP de interesse, utilizados na primeira reação de PCR convencional, no caso do SNP TLR1-rs5743618. Bem como dos iniciadores utilizados no pirosequenciamento deste SNP e do SNP TLR9-rs5743836

\begin{tabular}{|c|c|c|c|}
\hline Gene-SNP & Iniciadores $5^{\prime} \rightarrow 3^{\prime}$ & TM-PCR & TA \\
\hline TLR1-rs5743618 & $\begin{array}{c}\text { 1ª PCR Senso: TGTCTGGTACACGCATGGTC } \\
\text { 1ㄹ PCR Anti-senso: CAGCTTAATATTAATGGCTGCCC }\end{array}$ & $1343 \mathrm{pb}$ & $62^{\circ} \mathrm{C}$ \\
\hline TLR1-rs5743618 & $\begin{array}{l}\text { 2a PCR Senso: TCCTGAGATACCAGGGCAGAT } \\
\text { 2 PCR Anti-senso Biotinilado: ACCATGCTGGTGTTGGCTGT } \\
\text { Sequenciamento: CAGGGCAGATCCAAG (senso) }\end{array}$ & $231 \mathrm{pb}$ & $61^{\circ} \mathrm{C}$ \\
\hline TLR9-rs5743836 & $\begin{array}{c}\text { Senso Biotinilado: TCAGGGCCTTGGGATGTG } \\
\text { Anti-senso: AGGCAAAGGAGGGGTCAT } \\
\text { Sequenciamento: GAGACTTGGGGGAGTT (anti-senso) }\end{array}$ & $230 \mathrm{pb}$ & $61^{\circ} \mathrm{C}$ \\
\hline
\end{tabular}

TM-PCR: tamanho do produto de PCR; pb: pares de base; TA: temperatura de associação

Para a primeira reação da nested-PCR para o SNP do TLR1-rs5743618, para cada microtubo de $0.2 \mathrm{~mL}$ contendo $20 \mathrm{ng}$ de DNA, foi acrescentado um mix de soluções de dNTP Mix (0.2 mM), tampão de reação NH4Buffer (1x), albumina de soro bovino (BSA; $0.5 \mathrm{mg} / \mathrm{mL})$, cloreto de magnésio (1.5 mM), iniciadores $(200 \mathrm{nM}) \mathrm{e}$ enzima BioTAQ ${ }^{\circledR}$ DNA Polymerase $(0.5 \mathrm{U} / \mu \mathrm{L})$ num volume final de $25 \mu \mathrm{L}$, de acordo com as recomendações do fabricante (Bioline Reagents Ltd. - Londres, Reino Unido).

As reações preparadas foram submetidas à termociclagem no equipamento

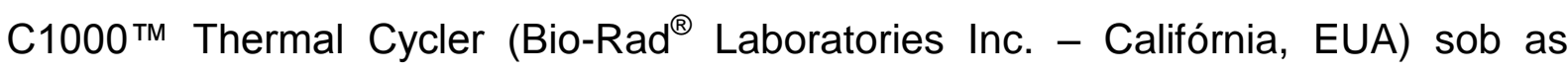
seguintes condições de ciclagem: 4 minutos a 95ํㅡ (desnaturação inicial do DNA), seguidos de 40 ciclos de 30 segundos a 95ํㅡ (desnaturação do DNA), 30 segundos a $62^{\circ} \mathrm{C}$ (temperatura de associação dos iniciadores), 45 segundos a $72^{\circ} \mathrm{C}$ (extensão do produto de $\mathrm{PCR}$ ); finalizando com 7 minutos a $72^{\circ} \mathrm{C}$ (extensão final dos produtos da PCR). A qualidade da reação foi verificada em gel de agarose $1.5 \%$, sendo considerada adequada quando observada uma banda intensa e única do produto de PCR, levando-se em consideração a posição do produto em relação ao marcador de peso molecular HyperLadder ${ }^{\mathrm{TM}}$ II 300-2000 pares de base (Bioline Reagents Ltd. Londres, Reino Unido).

Nas reações de PCR para pirosequenciamento, segunda reação da nestedPCR para o SNP do TLR1-rs5743618 e a PCR para o SNP do TLR9-rs5743836, para cada microtubo de $0.2 \mathrm{~mL}$ contendo a amostra, foi acrescentado um mix de dNTP, cloreto de magnésio (Bioline Reagents Ltd. - Londres, Reino Unido), PyroMark Reaction Buffer, HotStarTaq DNA Polymerase (QIAGEN ${ }^{\circledR}$ - Duesseldorf, Alemanha) e iniciadores, de acordo com as condições para cada iniciador descritas 
na Tabela 4.5 e as recomendações do fabricante.

Tabela 4.5 - Resumo das condições para a reação de PCR convencional de amostras de DNAteste com os iniciadores desenhados para a validação dos ensaios TaqMan para genotipagem selecionados para tais SNP

\begin{tabular}{cccccc}
\hline Gene & [dNTP] & {$[\mathrm{Mg}]$} & [iniciador] & [iniciador-B] & amostra \\
\hline TLR1-rs5743618 & $0.2 \mathrm{mM}$ & - & $300 \mathrm{nM}$ & $150 \mathrm{nM}$ & $0.5 \mu \mathrm{L}$ de amplificado* \\
TLR9-rs5743836 & $0.2 \mathrm{mM}$ & $2 \mathrm{mM}$ & $300 \mathrm{nM}$ & $150 \mathrm{nM}$ & $20 \mathrm{ng}$ de DNA \\
\hline
\end{tabular}

[dNTP]: concentração do mix de dNTP; [Mg]: concentração de magnésio; [iniciador]: concentração do iniciador; [iniciador-B]: concentração do iniciador biotinilado; amplificado*: produto resultante da primeira reação da nested-PCR

As reações preparadas foram submetidas à termociclagem no equipamento C1000 ${ }^{\mathrm{TM}}$ Thermal Cycler (Bio-Rad® Laboratories Inc. - Califórnia, EUA) sob as seguintes condições de ciclagem: 5 minutos a 95ํㅡ (desnaturação inicial do DNA), seguidos de 40 ciclos de 30 segundos a $94^{\circ} \mathrm{C}$ (desnaturação do DNA), 30 segundos a $61^{\circ} \mathrm{C}$ (temperatura de associação dos iniciadores), 30 segundos a $72^{\circ} \mathrm{C}$ (extensão do produto de PCR); finalizando com 10 minutos a $72^{\circ} \mathrm{C}$ (extensão final dos produtos da PCR). A qualidade da reação foi verificada em gel de agarose $1.5 \%$, sendo considerada adequada quando observada uma banda intensa e única do produto de PCR, levando-se em consideração a posição do produto em relação ao marcador de

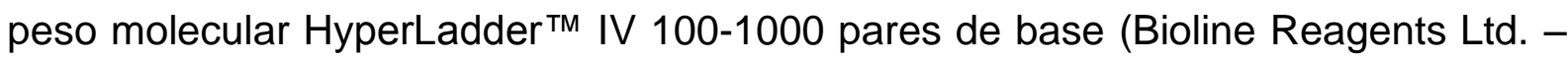
Londres, Reino Unido).

Quando consideradas adequadas as amostras eram submetidas ao processamento de purificação e isolamento da fita-simples de DNA marcada com o iniciador biotinilado (ANEXO D) para então serem submetidas ao pirosequenciamento no equipamento PyroMark Q96 MD, de acordo com as instruções do fabricante (QIAGEN ${ }^{\circledR}$ - Duesseldorf, Alemanha), sendo os resultados analisados com o programa PyroMark MD v1.0. 


\subsection{Análise de dados}

O equilíbrio de Hardy-Weinberg (HWE) foi verificado para cada SNP estudado nas amostras de cada grupo incluído (LPO, CEC de boca, CEC de laringe e controles). A associação entre os grupos casos (LPO, CEC de boca e CEC de laringe) e dados clínicos e os SNP analisados foram avaliados por T-teste (Student), qui-quadrado $\left(\mathrm{X}^{2}\right)$ e exato de Fischer. Também foi calculado o odds ratio (OR) com intervalo de confiança (IC) de 95\%, considerando nível de 5\% de significância $(p<0,05)$, por meio do uso do programa BioEstat versão $5.3^{8}$ (Prof. Dr. Manuel Ayres, Universidade federal do Pará). 


\section{RESULTADOS}

\subsection{Características gerais dos pacientes}

Foram incluídas neste estudo 339 amostras de pacientes, distribuídas nos seguintes grupos: LPO $(n=175)$, CEC de boca $(n=40)$, CEC de laringe $(n=35)$ e controles saudáveis $(n=89)$. As características gerais, bem como a comparação estatística $\left(X^{2}\right)$, dos pacientes incluídos em relação a sexo, idade e hábitos nocivos, tais como o uso de tabaco e álcool, estão sumarizadas na Tabela 5.1.

Relações estatisticamente significativas $\left(\mathrm{X}^{2}, p<0,01\right)$ foram observadas entre os pacientes com LPO e controles saudáveis em relação ao sexo, sendo o sexo feminino mais frequente nos pacientes com LPO. Entre os pacientes com CEC de boca e de laringe e os controles saudáveis houve diferença em relação aos hábitos de tabagismo e etilismo, mais frequentes nos grupos de pacientes afetados por neoplasia maligna.

Tabela 5.1 - Características clínicas dos pacientes cujas amostras congeladas de DNA, armazenadas no Laboratório de Genética da Faculdade de Medicina e Odontologia da Universidade do País Basco (UPV/EHU) foram incluídas nesta pesquisa

\begin{tabular}{cccccc}
\hline \multicolumn{2}{c}{ característica } & LPO & CEC de boca & CEC de laringe & Controle \\
\hline \multirow{2}{*}{ Idade } & & 175 & 40 & 35 & 89 \\
& média & 57.2 & 61.5 & 62.6 & 53.4 \\
& variação & $(21-90)$ & $(48-87)$ & $(48-86)$ & $(27-71)$ \\
\hline Sexo & masculino (\%) & $49(28)$ & $26(65)$ & $35(100)$ & $69(75.5)$ \\
& feminino (\%) & $126(72)$ & $14(35)$ & $0(0)$ & $20(22.5)$ \\
& p-value & $<0.001$ & 0.135 & $\mathbf{0 . 0 0 2}$ & \\
\hline tabagismo & sim (\%) & $35(20)$ & $34(85)$ & $27(77.1)$ & $28(31.5)$ \\
& não (\%) & $140(80)$ & $6(48.1)$ & $8(22.9)$ & $61(68.5)$ \\
& p-value & 0.047 & $<0.001$ & $<0.001$ & \\
\hline etilismo & sim (\%) & $38(21.7)$ & $29(72.5)$ & $29(82.9)$ & $28(31.5)$ \\
& não (\%) & $137(78.3)$ & $11(27.5)$ & $6(17.1)$ & $61(68.5)$ \\
& p-value & 0.098 & $<0.001$ & $<0,001$ & \\
\hline
\end{tabular}


Em relação aos pacientes incluídos com CEC de boca $(n=40)$, a língua foi a localização do tumor primário mais comum na maior parte dos casos contando com 18 pacientes afetados (45\%). E a maior parte destes pacientes foi diagnosticada no estágio inicial da doença, de acordo com o estadiamento pelo sistema TNM ${ }^{9}, 20$ (50\%) pacientes afetados por CEC de boca eram T1NOM0, ou seja, apresentavam lesão bucal de CEC com no máximo dois centímetros em sua maior extensão e não apresentavam metástase nem em linfonodos regionais, nem à distância. As características gerais dos pacientes afetados por CEC de boca estão representadas pelos Gráficos 5.2 e 5.3 .

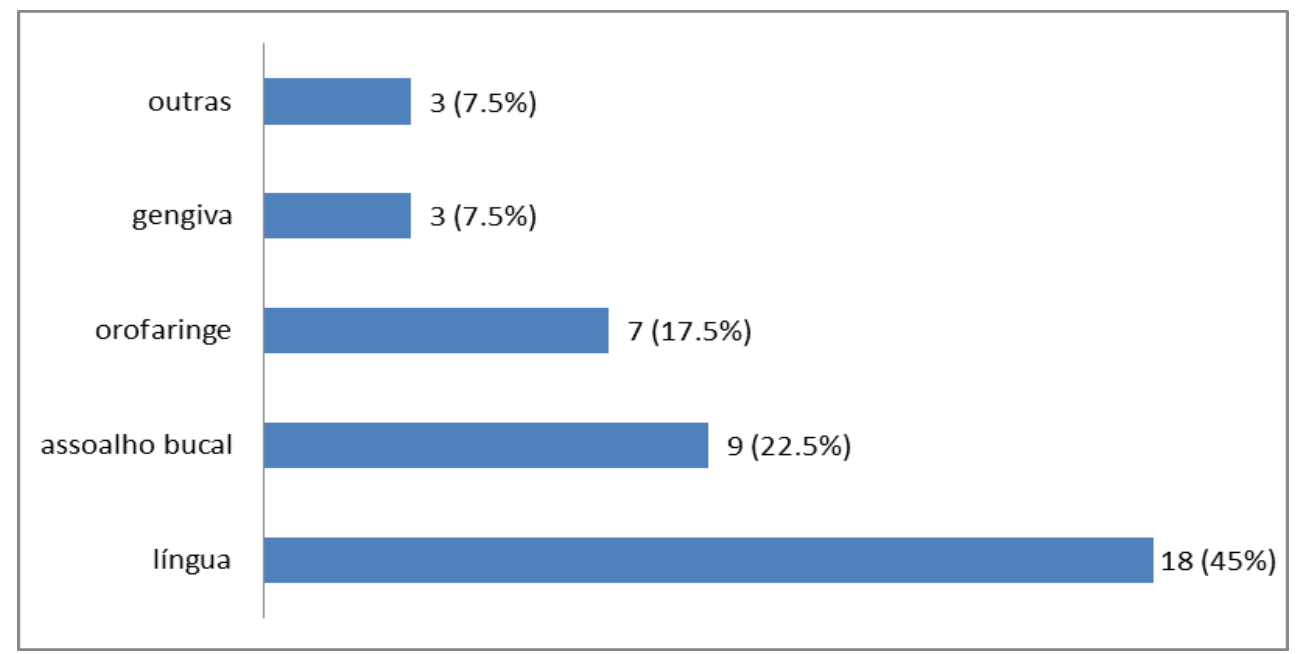

Gráfico 5.1 - Distribuição da localização primária das lesões de CEC de boca entre as amostras de pacientes incluídas nesta pesquisa

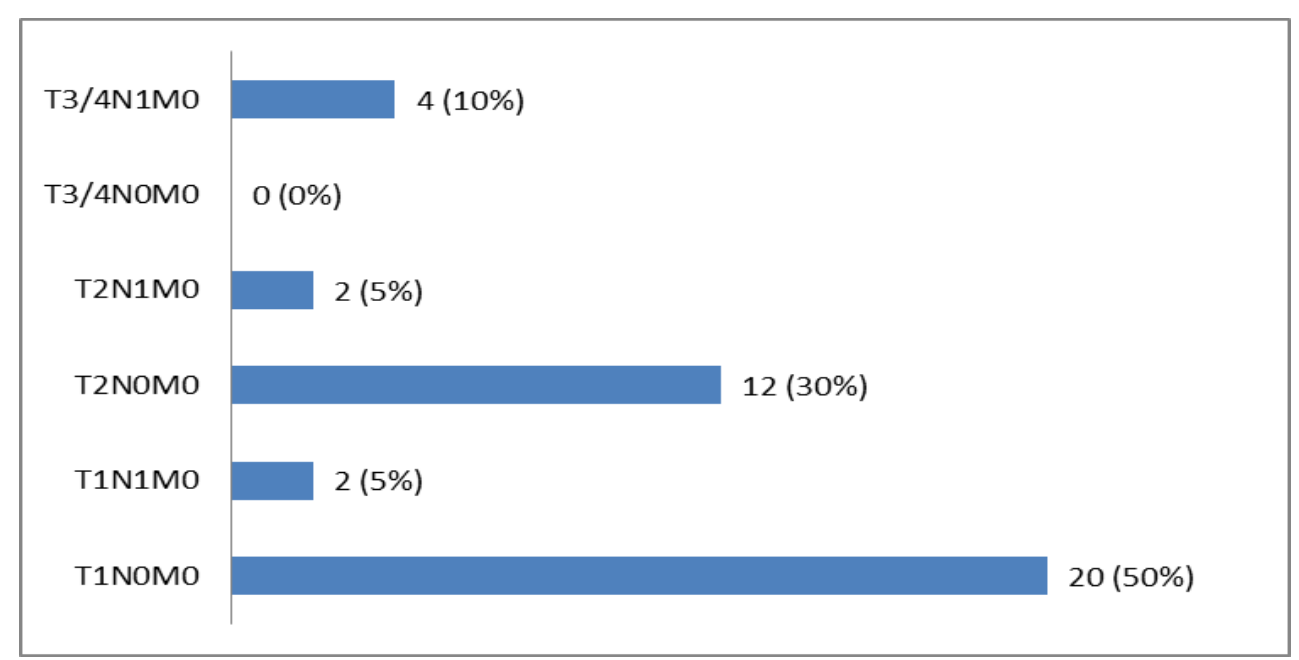

Gráfico 5.2 - Distribuição dos casos em relação ao estadiamento pelo sistema TNM (sendo T a extensão do tumor primário, $\mathrm{N}$ relacionado à metástase em linfonodos regionais e $\mathrm{M}$ metástase à distância) entre as amostras de pacientes incluídas nesta pesquisa

\footnotetext{
${ }^{9}$ http://www1.inca.gov.br/tratamento/tnm/tnm2.pdf
} 
Em relação aos pacientes com LPO, dos 175 pacientes incluídos, 46 (26.3\%) apresentavam LLO, o quadro clínico que apresenta maior susceptibilidade a transformação maligna; e apenas 6 (4\%) pacientes apresentavam acometimento cutâneo do líquen plano, além do mucoso. O restante dos pacientes $(n=123$, 69.7\%) apresentavam LPO idiopático.

A idade média foi semelhante entre os grupos LPO idiopático (57.4 anos de idade, variando entre 28-82) e LLO (56.4 anos de idade, variando entre 23-86), e não houve diferenças significativas quando comparado por meio do T-teste $(p=$ 0.065). Houve predomínio do sexo feminino em ambos os grupos, numa proporção de 3:1 (mulher:homem) nos pacientes com LPO idiopático e 2:1 nos com LLO, conforme ilustrado no Gráfico 5.3, porém a diferença não é estatisticamente significativa $\left(\mathrm{X}^{2} ; p=0.55\right)$.

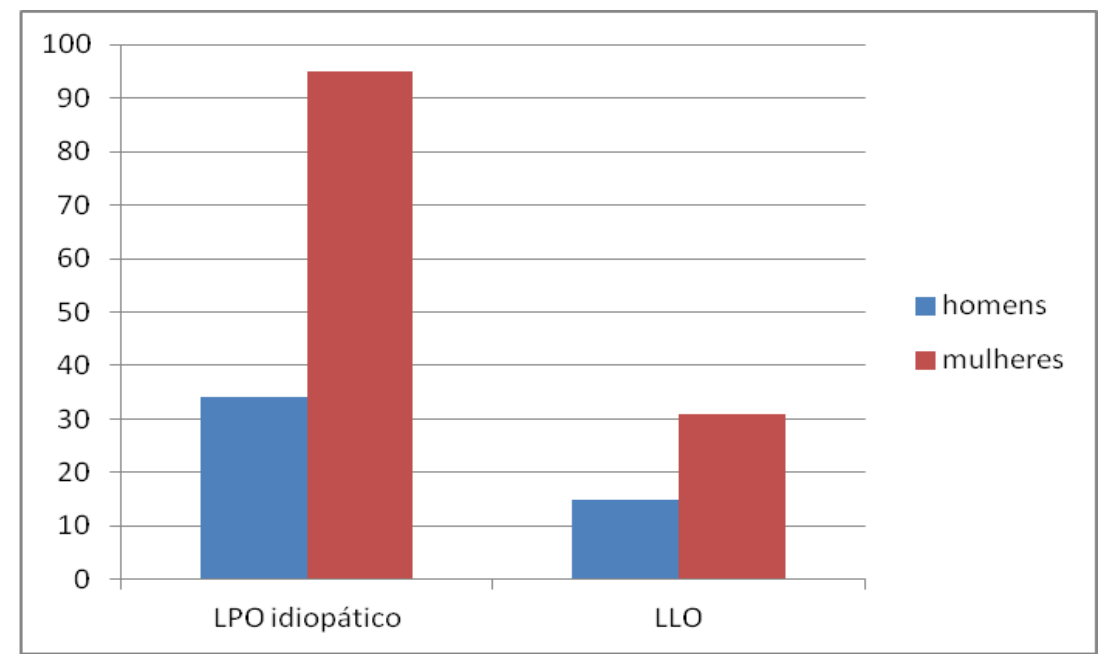

Gráfico 5.3 - Relação entre pacientes do sexo masculino e feminino nos grupos: LPO idiopático e LLO

Em relação aos hábitos nocivos de tabaco e álcool, também não foram encontradas diferenças significativas entre os grupos de LPO idiopático e LLO $\left(\mathrm{X}^{2}\right.$; tabagismo $p=0.79$ e etilismo $p=0.89$ ), como observado nos Gráficos 5.4 e 5.5. Sendo a porcentagem de indivíduos tabagistas nos grupos de LPO idiopático e LLO, respectivamente de $14.0 \%$ e $27.6 \%$, de ex-tabagistas $23.3 \%$ e $31.0 \%$; e etilistas $38.7 \%$ e $41.3 \%$. 


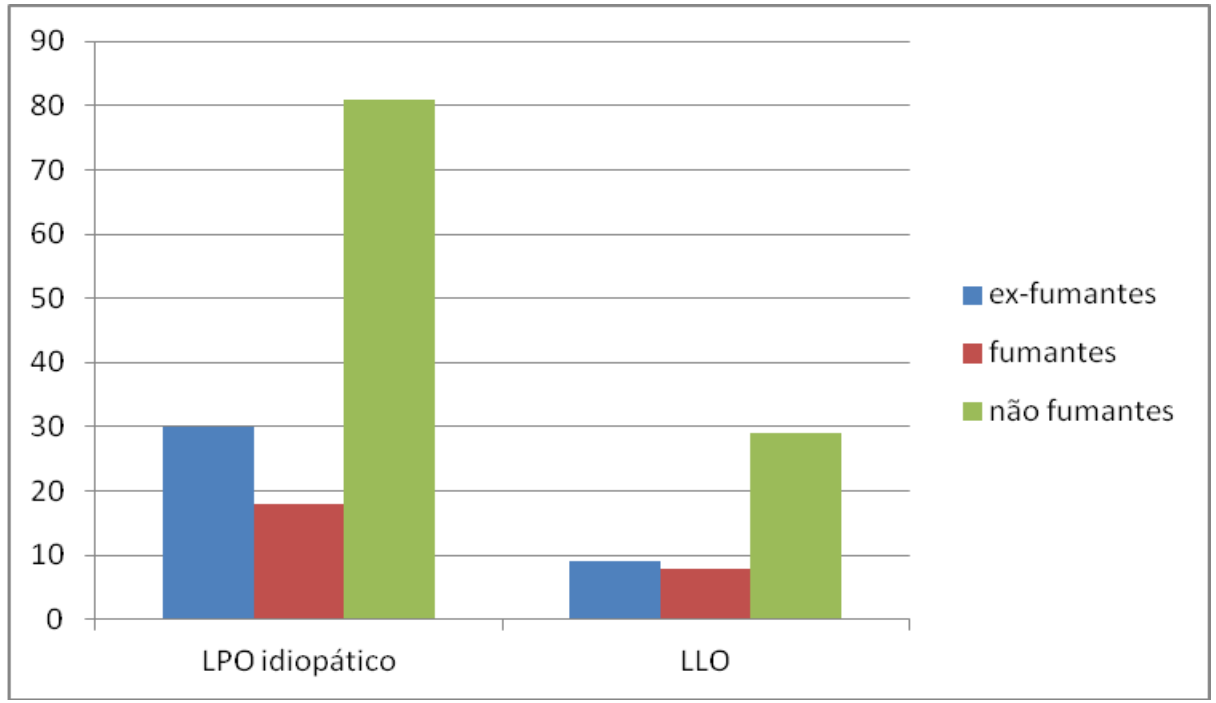

Gráfico 5.4 - Relação entre pacientes tabagistas, ex-tabagistas e não tabagistas nos grupos: LPO idiopático e LLO

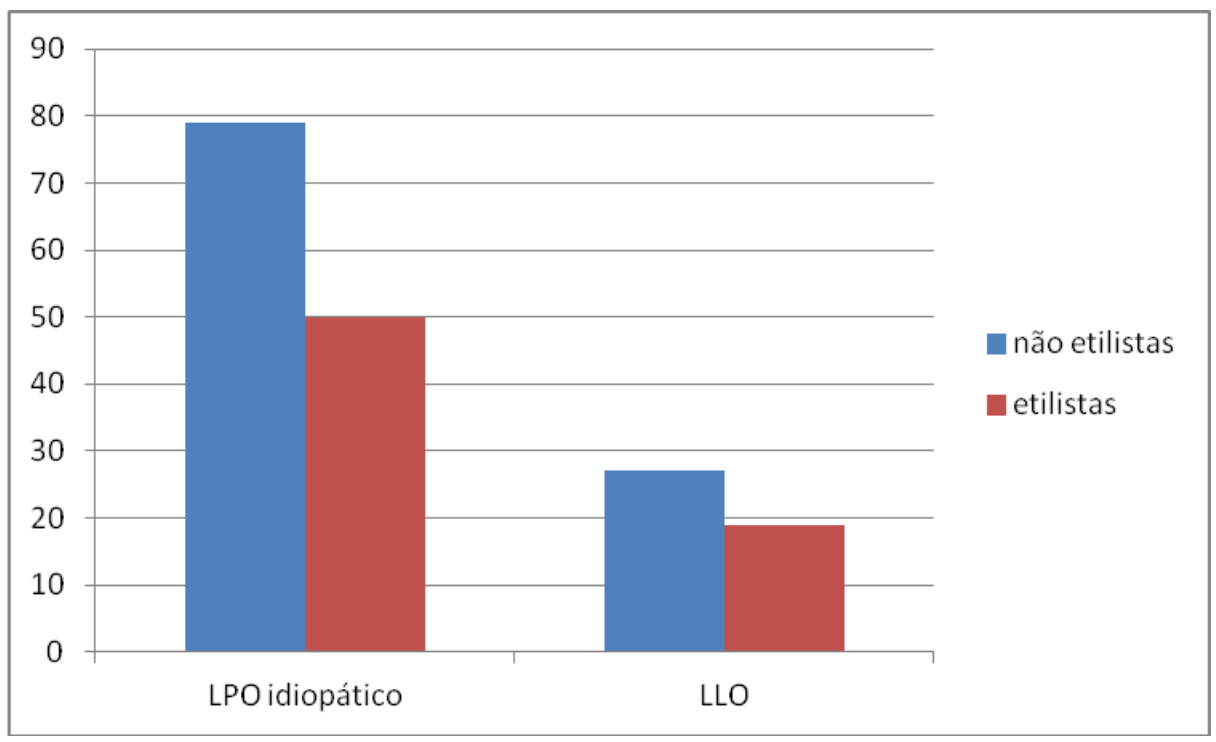

Gráfico 5.5 - Relação entre pacientes etilistas e não etilistas nos grupos: LPO idiopático e LLO

\subsection{Avaliação dos SNP genotipados}

As amostras genotipadas por ensaios TaqMan® analisadas pelo programa iQ5 Optical System Software, version 2.1 (Bio-Rad® Laboratories Inc. - Califórnia, EUA), foram consideradas adequadas quando apresentavam a clássica curva de amplificação, que inclui quatro fases: ruído de fundo, exponencial, linear e platô. 
Nesta metodologia, quando se observavam duas curvas de amplificação muito semelhantes para os dois fluoróforos, a amostra era considerada heterozigota. Quando uma das curvas era considerada adequada e a outra não, a amostra era considerada homozigota para o alelo marcado pelo fluoróforo da curva de amplificação satisfatória. A relação da marcação fluoróforos-alelo foi fornecida pelo fabricante dos ensaios TaqMan® para genotipagem (Applied Biosystems Califórnia, EUA) e validada previamente conforme descrito na seção anterior. Finalmente, os dados de todas as amostras eram compilados em um gráfico de discriminação alélica, ilustrado pela Figura 5.1.

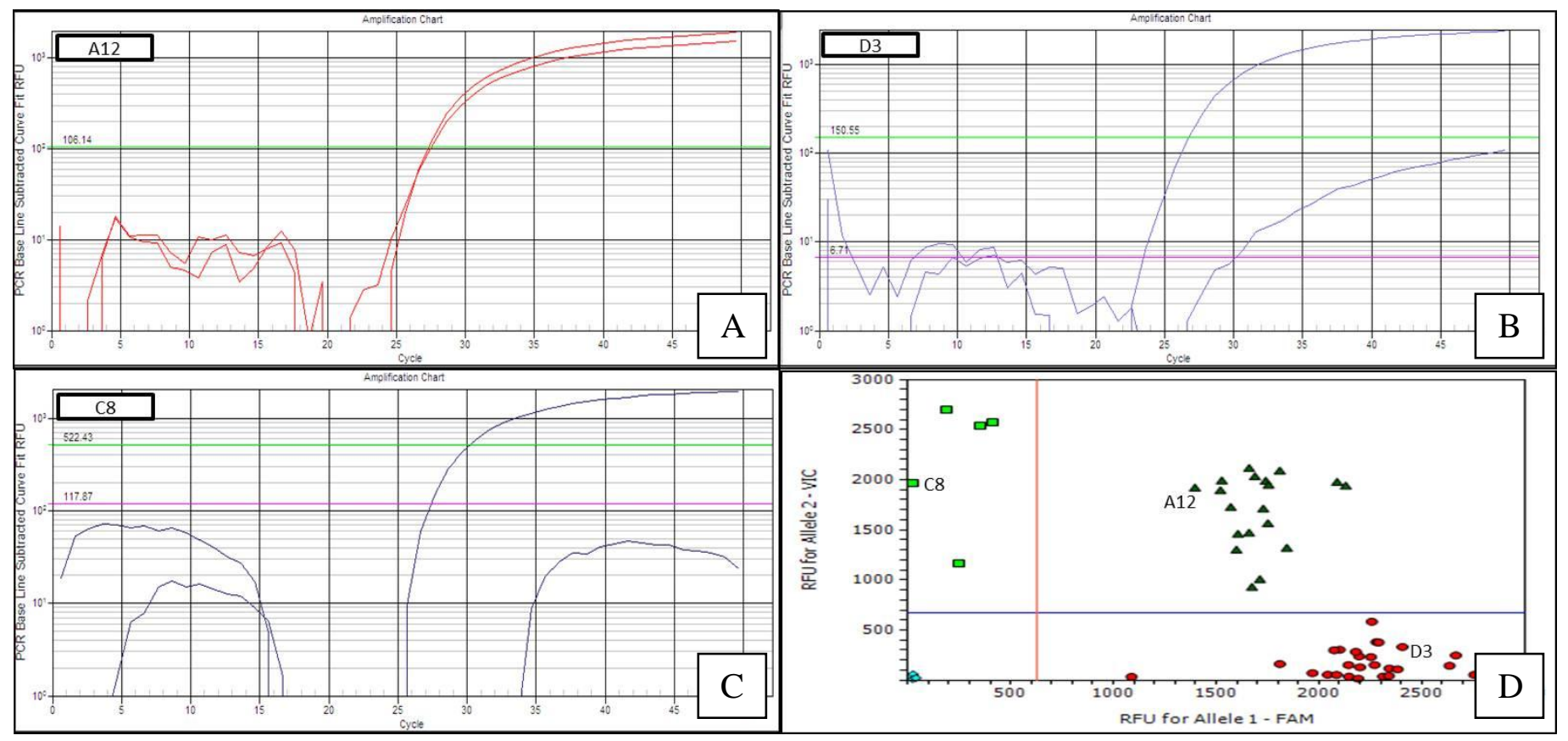

Figura 5.1 - Ilustração das possíveis curvas de amplificação e os possíveis genótipos. A: amostra A12 apresenta duas curvas clássicas de amplificação - amostra heterozigota, B: D3 apresenta a curva clássica de amplificação apenas para o alelo marcado por $\mathrm{FAM}^{\circledR}$ amostra homozigota, C: C8 apresenta a curva clássica de amplificação apenas para o alelo marcado por VIC $^{\circledR}$ - amostra homozigota. D: gráfico da discriminação alélica das amostras analisadas

Quanto às amostras genotipadas por pirosequenciamento, se a quantidade de luz emitida pela incorporação de um aminoácido à sequência molde passasse no controle de qualidade do programa PyroMark MD v1.0 (QIAGEN ${ }^{\circledR}$ - Duesseldorf, Alemanha), o genótipo da amostra era determinado pela leitura do pirograma de acordo com os picos de emissão luminosa. Dois picos intermediários, um por alelo, representavam amostras heterozigotas e um pico alto único, em um único alelo, representava amostras homozigotas, como ilustrado pela Figura 5.2. 


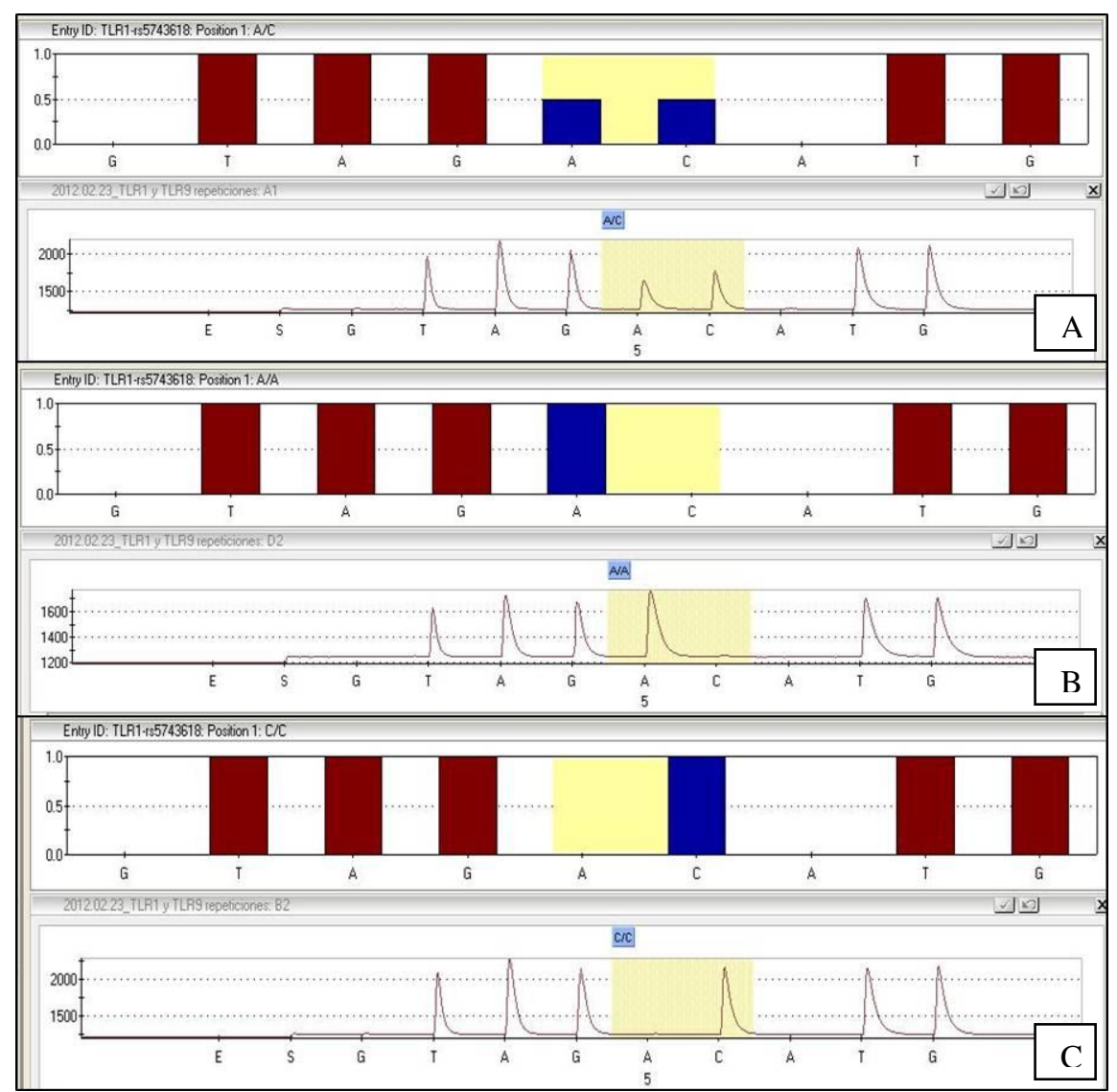

Figura 5.2 - llustração dos possíveis pirogramas obtidos a partir do pirosequenciamento. A: dois picos de intensidade intermediária e semelhante - amostra heterozigota (AC), B: pico único e com o dobro da altura dos anteriores - amostra homozigota (AA), C: pico único e com o dobro da altura dos anteriores - amostra homozigota (CC)

Os dados obtidos a partir de ambas as metodologias de genotipagem foram tabulados e, após a verificação da consistência do Equilíbrio de Hardy-Weinberg, a análise estatística foi realizada por meio dos testes $X^{2}$ e exato de Fischer para as frequências dos genótipos e para a avaliação do risco (odds ratio - razão de chances) de desenvolvimento das doenças analisadas, bem como para a correlação com parâmetros clínicos (BioEstat versão 5.3).

O alelo mutado A do SNP TLR2-rs4696480 foi relacionado significativamente ao risco aumentado de desenvolvimento de CEC de boca ( $p=$ 0,033). O genótipo heterozigoto AT aumenta o risco de desenvolver CEC de boca 5.3 vezes em comparação ao genótipo selvagem TT $(\mathrm{OR}=5.3,95 \% \mathrm{Cl}=1.19$ 13.63), enquanto o genótipo homozigoto mutado AA aumenta o risco em 6.6 vezes $(\mathrm{OR}=6.6,95 \% \mathrm{Cl}=1.30-33.89)$. Os genótipos mutantes foram mais comuns, embora não significativamente, em pacientes com CEC de boca (AT-52.5\%, AA$32.5 \%$ ) e LPO (AT-49.1\%, AA-29.1\%). Estes dados estão sumarizados na Tabela 5.2 . 
Tabela 5.2 - Análise dos resultados da genotipagem do SNP TLR2-rs4696480, frequência e odds ratio de cada genótipo e análise estatística, das diferentes doenças estudadas (LPO, CEC de Boca, CEC de laringe) em relação aos controles

\begin{tabular}{ccccc}
\hline & Controle & CEC de boca & CEC de laringe & LPO \\
\hline TT $(\mathrm{n})$ & 31 & 6 & 6 & 38 \\
$\%$ & 34.8 & 15 & 17.1 & 21.7 \\
OR $(95 \% \mathrm{Cl})$ & & 1 & 1 & 1 \\
\hline $\mathrm{AT}(\mathrm{n})$ & 34 & 21 & 18 & 86 \\
$\%$ & 38.2 & 52.5 & 51.4 & 49.1 \\
OR $(95 \% \mathrm{Cl})$ & & $5,313(1,194-13,632)$ & $4,199(1,056-16,693)$ & $1,923(0,948-3,902)$ \\
\hline $\mathrm{AA}(\mathrm{n})$ & 24 & 13 & 11 & 51 \\
$\%$ & 27 & 32.5 & 31.4 & 29.1 \\
OR $(95 \% \mathrm{Cl})$ & & $6,642(1,302-33,886)$ & $2,268(0,507-16,151)$ & $2,111(0,971-4,59)$ \\
\hline$\%$ p-value & & 0.067 & 0.145 & 0.063 \\
\hline OR p-value & & $\mathbf{0 . 0 3 3 ^ { \star }}$ & 0.106 & 0.108 \\
\hline
\end{tabular}

(n): número de indivíduos; \%: porcentagem de indivíduos; OR (95\% Cl): odds ratio $(95 \%$ intervalo de confiança); \% p-value: análise estatística da frequência dos genótipos $\left(X^{2}\right)$; OR p-value: análise estatística do risco (razão de chances) de cada genótipo $\left(\mathrm{X}^{2}\right)$

As frequências dos genótipos heterozigotos dos SNP TLR4-rs1927911 (AG$54.3 \%, p=0.018)$ e TLR9-rs352139 (CT-60\%, $p=0.046$ ) foram significativamente mais comuns no grupo de CEC de laringe, no entanto esses SNP não se apresentam relacionados ao risco aumentado de desenvolvimento de CEC de laringe, como ilustrado pelas Tabelas 5.3 e 5.4 .

Tabela 5.3 - Análise dos resultados da genotipagem do SNP TLR4-rs1927911, frequência e odds ratio de cada genótipo e análise estatística, das diferentes doenças estudadas (LPO, CEC de Boca, CEC de laringe) em relação aos controles

\begin{tabular}{ccccc}
\hline & Controle & CEC de boca & CEC de laringe & LPO \\
\hline GG & 54 & 20 & 12 & 98 \\
$\%$ & 60.7 & 50 & 34.3 & 56 \\
OR (95\% Cl) & & 1 & 1 & 1 \\
\hline AG & 32 & 19 & 19 & 65 \\
$\%$ & 36 & 47.5 & 54.3 & 37.1 \\
OR (95\% Cl) & & $1,4(0,469-4,183)$ & $2,274(0,672-7,168)$ & $1,257(0,681-2,319)$ \\
\hline AA & 3 & 1 & 4 & 12 \\
$\%$ & 3.3 & 2.5 & 11.4 & 6.9 \\
OR (95\% Cl) & & $0,5770,086-77,207)$ & $7,107(0,180-280,357)$ & $2,195(0,508-9,493)$ \\
\hline p-value & & 0.465 & $\mathbf{0 . 0 1 8 ^ { \star }}$ & 0.47 \\
\hline OR p-value & & 0.747 & 0.261 & 0.471 \\
\hline
\end{tabular}

(n): número de indivíduos; \%: porcentagem de indivíduos; OR $(95 \% \mathrm{Cl})$ : odds ratio $(95 \%$ intervalo de confiança); \% p-value: análise estatística da frequência dos genótipos $\left(X^{2}\right)$; OR p-value: análise estatística do risco (razão de chances) de cada genótipo $\left(X^{2}\right)$ 
Tabela 5.4 - Análise dos resultados da genotipagem do SNP TLR9-rs352139, frequência e odds ratio de cada genótipo e análise estatística, das diferentes doenças estudadas (LPO, CEC de Boca, CEC de laringe) em relação aos controles

\begin{tabular}{ccccc}
\hline & Controle & CEC de boca & CEC de laringe & LPO \\
\hline TT & 16 & 7 & 8 & 37 \\
$\%$ & 18 & 17.5 & 22.9 & 21.1 \\
OR $(95 \% \mathrm{Cl})$ & & 1 & 1 & 1 \\
\hline $\mathrm{CT}$ & 37 & 21 & 21 & 91 \\
$\%$ & 41.6 & 52.5 & 60 & 52 \\
OR (95\% Cl) & & $0,861(0,182-4,061)$ & $1,167(0,242-5,621)$ & $0,916(0,418-2,009)$ \\
\hline $\mathrm{CC}$ & 36 & 12 & 6 & 47 \\
$\%$ & 40.4 & 30 & 17.1 & 26.9 \\
OR (95\% Cl) & & $0,656(0,131-3,301)$ & $0,365(0,659-2,248)$ & $0,507(0,222-1,158)$ \\
\hline p-value & & 0.462 & $\mathbf{0 . 0 4 6}$ & 0.079 \\
\hline OR p-value & & 0.848 & 0.218 & 0.14 \\
\hline
\end{tabular}

(n): número de indivíduos; \%: porcentagem de indivíduos; OR (95\% Cl): odds ratio $(95 \%$ intervalo de confiança); \% $p$-value: análise estatística da frequência dos genótipos $\left(X^{2}\right)$; OR $p$-value: análise estatística do risco (razão de chances) de cada genótipo $\left(X^{2}\right)$

As análises da frequência dos genótipos e risco dos demais SNP nos TLR não demostraram nenhuma associação significativa (APÊNDICE B).

Em relação ao SNP TLR2-rs4696480, relacionado ao risco aumentado de desenvolvimento de CEC de boca, foi realizada a avaliação entre a presença do alelo mutado $\mathrm{A}$, presente em $85 \%$ dos pacientes com CEC de boca, e as características clínicas destes pacientes. Não houve diferenças significativas em relação aos hábitos destes pacientes entre aqueles que apresentavam 0 alelo mutado ou não $(p>0.05)$; e apesar de metástases em linfonodos regionais e tumores em estágios avançados estarem presentes apenas em indivíduos com o genótipo AA e AT, esta relação não apresentou diferença significativa (Tabela 5.5).

Tabela 5.5 - Relação entre a presença do alelo A do SNP TLR2-rs4696480 em pacientes com CEC de boca e as características clínicas: hábitos nocivos e estadiamento TNM

\begin{tabular}{cccc}
\hline & $\mathrm{TT}$ & $\mathrm{AA}+\mathrm{AT}$ & $p^{*}$ \\
\hline $\mathrm{n}(\%)$ & $6(15)$ & $34(85)$ & \\
só tabaco & $1(16.7)$ & $8(23.5)$ & 0.590 \\
só álcool & 0 & $1(3)$ & 0.850 \\
tabaco+álcool & $3(50)$ & $20(58.8)$ & 0.511 \\
sem hábitos & $2(33.4)$ & $4(11.8)$ & 0.215 \\
T1/T2N0M0 & $6(100)$ & $26(76.5)$ & 0.236 \\
T1/2N1M0 & 0 & $4(11.8)$ & 0.507 \\
T3/T4N0M0 & 0 & 0 & 1.000 \\
T3/T4N1M0 & 0 & $4(11.8)$ & 0.507 \\
\hline$p^{*}$ teste exato de Fischer & &
\end{tabular}


O SNP TLR2-rs4696480 também foi encontrado numa alta frequência nos pacientes com LPO; desta forma foi avaliada a presença do alelo mutado em relação às diferentes formas de LPO incluídas neste grupo, LPO idiopático e LLO. Nesta análise foi possível observar relação significativa da frequência do alelo mutado em ambos os grupos em relação ao grupo controle, especialmente em relação a frequência de indivíduos heterozigotos (LPO idiopático: AT-48.1\%, $p=0.045$ e LLO: AT-54.3\%, $p=0.0003$ ).

Além disso, com esta nova análise, foi possível relacionar significativamente o risco (razão de chances) do desenvolvimento de LLO e a presença do alelo mutado do SNP TLR2-rs4696480 ( $p=0.0223)$. O genótipo heterozigoto AT aumenta o risco de desenvolver LLO 4.6 vezes em comparação ao genótipo selvagem TT $(\mathrm{OR}=4.6,95 \% \mathrm{Cl}=1.55-13.38)$, enquanto o genótipo homozigoto mutado $\mathrm{AA}$ aumenta o risco em 4.1 vezes $(\mathrm{OR}=4.1,95 \% \mathrm{Cl}=1.33-12.88)$. Esta relação não foi observada nos pacientes com LPO idiopático. Estes dados estão sumarizados na Tabela 5.6.

Tabela 5.6 - Análise dos resultados da genotipagem do SNP TLR2-rs4696480, frequência e odds ratio de cada genótipo e análise estatística, das diferentes formas de LPO incluídas no estudo (LPO idiopático e LLO) em relação aos controles

\begin{tabular}{cccc}
\hline & Controle & LPO idiopático & LLO \\
\hline total $(\mathrm{n})$ & 89 & 129 & 46 \\
\hline $\mathrm{TT}(\mathrm{n})$ & 31 & 33 & 5 \\
$\%$ & 34.8 & 25.6 & 10.9 \\
OR $(95 \% \mathrm{Cl})$ & & 1 & 1 \\
\hline $\mathrm{AT}(\mathrm{n})$ & 34 & 62 & 25 \\
$\%$ & 38.2 & 48.1 & 54.3 \\
OR $(95 \% \mathrm{Cl})$ & & $1.7(0.899-3.263)$ & $4.6(1.554-13.378)$ \\
\hline $\mathrm{AA}(\mathrm{n})$ & 24 & 35 & 16 \\
$\%$ & 27 & 26.3 & 34.8 \\
OR $(95 \% \mathrm{Cl})$ & & $1.4(0.670-2.798)$ & $4.1(1.326-12.883)$ \\
\hline$\%$ p-value & & $\mathbf{0 . 0 4 5 4 ^ { \star }}$ & $\mathbf{0 . 0 0 0 3}^{\star}$ \\
\hline OR p-value & & 0.139 & $\mathbf{0 . 0 2 2 3}^{*}$ \\
\hline
\end{tabular}

(n): número de indivíduos; \%: porcentagem de indivíduos; OR $(95 \% \mathrm{Cl})$ : odds ratio (95\% intervalo de confiança); \% p-value: análise estatística da frequência dos genótipos $\left(X^{2}\right)$; OR p-value: análise estatística do risco (razão de chances) de cada genótipo $\left(X^{2}\right)$ 


\section{DISCUSSÃO}

\subsection{Considerações em relação à revisão de literatura realizada}

Em relação às publicações revisadas neste trabalho pode-se considerar que a expressão gênica e proteica de alguns receptores Toll-like, em amostras de pacientes com LPO está alterada, sendo reduzida no caso do TLR2 e aumentada no caso dos TLR4 e TLR9; estas alterações estão relacionadas com o desequilíbrio da resposta imunológica Th1, culminando com o aumento exagerado da produção de citocinas inflamatórias, tais como IFN e IL-12 (11), e com a ativação de linfócitos T auto-reativos, no caso dos TLR2 e TLR9 (63); além da associação aos processos de perpetuação das lesões e resistência à apoptose, no caso do TLR4 (64). As consequências do efeito anti-apoptótico excessivo são desconhecidas e podem inclusive estar relacionadas ao potencial de transformação maligna de alguns tipos de lesão de LPO. Todavia, nenhum dos estudos acerca da expressão dos TLR em LPO realizou a diferenciação entre pacientes com LPO idiopático e LLO. E não existem investigações publicadas na literatura sobre a herança de polimorfismos tipo SNP no LPO e a relação com os eventos acima descritos.

Por sua vez, os resultados da relação de expressão dos TLR e células tumorais de carcinoma epidermóide de cabeça e pescoço, incluindo o CEC de boca, especificamente TLR2, TLR3, TLR4 e TLR9 é anormal. Sendo a expressão dos TLR2, TLR3 e TLR9 elevada e a do TLR4 diminuída. No entanto, provavelmente, estas alterações não são responsáveis pelo início da tumorigênese do CEC de boca e de cabeça e pescoço, mas se relacionam a outros fenômenos, tais como: a alta expressão de TLR2 foi correlacionada com resistência à apoptose (28-31); a também alta expressão do TLR3 foi significativamente associada ao crescimento tumoral, a tumores pouco diferenciados e à invasão $(6,29,30,33,34)$; a baixa expressão de TLR4 era frequente em tumores pouco diferenciados e também correlacionada à alta taxa de proliferação e resistência à apoptose mediada por drogas (4, 29-32, 38, 39); e, por fim, a elevada expressão do TLR9 estava associada a lesões avançadas e baixos índices de sobrevida global (32, 40-42). 
No entanto, grande parte dos estudos revisados, quanto à expressão dos TLR em CEC de boca e de cabeça e pescoço, utilizaram linhagens diversas de culturas de células malignas destes tumores; e aqueles com amostras de pacientes, frequentemente utilizaram amostras de arquivo (tecidos fixados em formalina e embebidos em parafina), diminuindo a qualidade dos resultados em relação a análise de tecido fresco. Além disso, em alguns estudos o tamanho da amostra era insuficiente, proporcionando resultados heterogêneos e comprometendo uma avaliação global adequada.

Tais alterações podem ser determinadas pela presença de polimorfismos (SNP). Estes, em regiões codificantes do gene, podem resultar em substituições de aminoácidos que alteram a função da proteína; SNP em regiões não codificantes, como íntrons e regiões promotoras, podem produzir splicing alterados dos éxons, reduzir a estabilidade do RNAm, prejudicar a síntese de fatores de transcrição, ou alterar a estrutura dos códons de iniciação da tradução, o que pode levar a alteração na transcrição do gene $(96,107)$.

Em relação aos polimorfismos e a relação com as doenças estudadas, LPO e CEC de boca e de laringe, os estudos ainda são incipientes. No caso do LPO não existem relatos e em relação ao CEC de boca, existem poucos estudos e a grande maioria se dedica à investigação de SNP em CEC de outras regiões de cabeça e pescoço, como nasofaringe. Ainda assim muitos destes SNP investigados apresentavam baixa MAF (SNP raros) e alguns deles não apresentavam designação rs, o que dificulta o desenho de um estudo que demonstre resultados concretos.

Uma vez que SNP com baixa MAF exigem grandes tamanhos de amostra e a ausência de rs dificulta a consulta destes SNP em diversos bancos de dados, estes foram excluídos da análise no presente estudo. A revisão de literatura a respeito da relação dos SNP em TLR e as neoplasias malignas, elaborada por Kutikhin (64), fornece um panorama do que já foi realizado neste campo com resultados interessantes, mas ainda pouco explorado pelas investigações atuais, foi também levado em consideração para a seleção dos SNP em genes dos TLR estudados, além das características descritas no item 4.3. 


\subsection{Considerações em relação à análise da genotipagem realizada para SNP nos genes de TLR}

No que diz respeito à análise da genotipagem proposta por este trabalho, em relação às características gerais da população incluída neste estudo, não foram observadas diferenças estatisticamente significativas em relação à idade dos pacientes de todos os grupos incluídos: LPO, CEC de boca, CEC de laringe e controles, demostrando o pareamento proposto para o estudo, segundo o desenho selecionado de ensaio caso-controle.

O sexo feminino foi significativamente predominante nos pacientes com LPO e o sexo masculino nos pacientes com CEC de laringe $(p<0,01)$. Os hábitos nocivos, tabagismo e etilismo, foram estatisticamente relacionados aos pacientes com neoplasias malignas (CEC de boca e de laringe) $(p<0,01)$. Uma vez que os pacientes foram selecionados consecutivamente entre aqueles que buscavam atendimento clínico, o predomínio do sexo feminino em pacientes com LPO era esperado de acordo com estudos de investigação epidemiológica publicados na literatura, que revelaram que o LPO é uma doença inflamatória crônica com predomínio em mulheres acima dos 40 anos, tal como observado na amostra incluída neste estudo (ver Tabela 5.1) $(44,45)$.

De acordo com a literatura, a incidência de CEC de boca é mais alta no País Basco, região de onde é proveniente toda a amostra estudada, em relação a outras regiões da Espanha $(70,108)$, sendo que as regiões de maior incidência na Europa em geral são França e Hungria (71). Quanto ao sexo dos pacientes, anteriormente o CEC de boca ocorria predominantemente em indivíduos do sexo masculino, mas este quadro foi alterado globalmente, visto que houve um aumento no diagnóstico de CEC de boca em mulheres a partir da década de 90 , atribuído ao aumento de consumo de tabaco e álcool (71). Esta mudança na incidência em relação ao sexo dos indivíduos pode ser observada pela ausência de predomínio do sexo masculino entre os pacientes com CEC de boca e, o predomínio de homens no grupo dos pacientes com CEC de laringe pode ter sido influenciado pelo acaso em função da inclusão consecutiva dos pacientes que buscaram diagnóstico e tratamento (sem seleção dos casos) na Unidade de Medicina Oral e Patologia Oral e Maxilofacial da Faculdade de Medicina e Odontologia da Universidade do País 
Basco (UPV/EHU). E embora a revisão de Warnakulasuriya (67) sugira que alguma característica masculina esteja relacionada ao risco do desenvolvimento do CEC de faringe, esta relação com o CEC da região subsequente, a laringe, não foi abordada.

A relação entre hábitos nocivos como consumo crônico de tabaco e álcool foi significativamente predominante nos grupos de pacientes com CEC de boca e de laringe. Estes fatores de risco clássicos são atribuídos a um aumento de $80 \%$ na chance de desenvolvimento destas lesões malignas (70-72). Esta relação foi obtida em relação à população controle, selecionada espontaneamente entre os indivíduos que procuravam tratamento odontológico, população esta que, de acordo com o último senso no País Basco (Espanha), apresenta altas taxas de consumo de tabaco e álcool, sendo que aproximadamente $59 \%$ dos homens e $30 \%$ das mulheres são consumidores usuais de tabaco e álcool (70). Embora alguns estudos apontem alguma participação do álcool na carcinogênese bucal (70), outros o apontam como um agente promotor atuando conjuntamente com os carcinógenos do tabaco, sendo ainda controverso os efeitos do álcool consumido cronicamente (109).

Em relação à localização do tumor primário, a língua foi a região mais frequentemente acometida (45\%), seguida do assoalho bucal (22.5\%), orofaringe (17.5\%) e gengiva (7.5\%); assim como relatado na literatura (71). Outras regiões como mucosa jugal e palato foram raramente acometidas na amostra estudada (ver Gráfico 5.1).

Interessantemente a maior parte dos casos incluídos foi diagnosticada precocemente. De acordo com a avaliação do estadiamento TNM destes pacientes, $50 \%$ da amostra era T1N0M0, ou seja, apresentavam lesão bucal de CEC com no máximo dois centímetros em sua maior extensão e não apresentavam metástase nem em linfonodos regionais, nem à distância. Apenas $10 \%$ da amostra era constituída por pacientes em estágios avançados de CEC de boca com lesões extensas (maiores de 4 centímetros) e invadindo estruturas adjacentes com metástases em linfonodos regionais (T3/T4N1M0). Embora as metástases sejam mais frequentes em lesões avançadas, $5 \%$ dos pacientes manifestando lesões iniciais já apresentavam metástases em linfonodos regionais, indicando que provavelmente eram acometidos por lesões mais agressivas (ver Gráfico 5.2).

A estatística brasileira em relação ao estadiamento de diagnóstico de CEC de boca é oposta à observada nesta amostra de pacientes, a maior parte dos casos é ainda diagnosticada em estágios avançados (110-112), apesar dos esforços 
realizados por campanhas de prevenção e diagnóstico precoce do câncer de boca, promovidas por diversos órgãos como prefeituras municipais e entidades de classe, apesar de que estes dados mais recentes aparentemente não se encontram publicados, ou não foram identificados na revisão de literatura deste trabalho. A título de exemplo, na cidade de São Paulo, registram-se campanhas da Prefeitura do Município de São Paulo, da Associação Paulista de Cirurgiões Dentistas e do Conselho Regional de Odontologia.

Porém, como ilustrado por dois levantamentos epidemiológicos de duas regiões brasileiras, estado de Alagoas (Nordeste) e São Paulo (Sudeste), o diagnóstico em estádios III e IV acontece em 78\% e 53\%, respectivamente, dos pacientes acometidos por câncer de boca $(110,111)$. Apesar de a cavidade bucal representar sítio de fácil acesso à inspeção, o fato da lesão inicial ser indolor e o despreparo de muito profissionais de saúde foram apontados como possíveis explicações para estas lastimáveis estatísticas (112).

Tendo em vista que o diagnóstico precoce está relacionado com melhores taxas de sobrevida e possibilidade de cura, é fundamental o investimento em qualificação dos profissionais acerca da detecção destas lesões em estágios iniciais, bem como da identificação e acompanhamento de pacientes que apresentam desordens orais com potencial de transformação maligna.

Além das leucoplasias e eritroplasias, classicamente relatadas como lesões bucais com evidência de transformação maligna, o líquen plano oral também é considerado pela OMS como uma desordem oral com potencial de transformação maligna, embora este tema seja bastante controverso, em uma taxa de 0 a $6.25 \%$ dos pacientes com LPO. Os estudos a respeito da transformação maligna de lesões de LPO são bastante heterogêneos, alguns deles com baixo nível de evidência, proporcionando ainda mais controvérsia e este tema. Classicamente, as lesões atróficas, erosivo-ulceradas e atípicas de LPO, as LLO, seriam as que apresentam maior potencial de transformação (17).

Desta forma, no total de 175 pacientes com LPO incluídos no estudo, 69.7\% apresentavam o LPO idiopático ou clássico, 4\% apresentavam envolvimento cutâneo, além das lesões bucais, e 26.3\% apresentavam lesões atípicas de LPO, classificadas como LLO, de acordo com a proposta sugerida pelo próprio Prof. Aguirre, orientador estrangeiro deste trabalho (50). 
A baixa ocorrência de lesões cutâneas (4\%) nos pacientes com LPO e o acometimento exclusivo da mucosa bucal (69.7\%) em uma porcentagem superior a $30 \%$, descrita na literatura (45), está relacionada à utilização de um centro odontológico para a captação destes pacientes.

Em relação à comparação entre os grupos LPO idiopático e LLO, não houve diferenças significativas em relação à idade e sexo, sendo 56-57 anos a idade média dos pacientes e o sexo feminino mais frequente em ambos os grupos, embora a proporção mulheres/homens acometidos por LPO idiopático fosse maior $(p=0.55)$. Também não foi observada relação entre os hábitos de consumo de tabaco e álcool e os grupos LPO idiopático e LLO, sendo semelhantes as proporções de indivíduos tabagistas $(p=0.79)$ e etilistas $(p=0.89)$ (ver Gráficos 5.3, 5.4 e 5.5). Desta forma, as possíveis variações entre estes grupos não apresentam os fatores de idade, sexo, tabaco e álcool como fatores de confundimento.

A avaliação estatística dos dados obtidos pela genotipagem de oito diferentes SNP em diferentes TLR (ver Tabela 4.1) por ambas as metodologias laboratoriais, ensaios TaqMan® e pirosequenciamento, forneceu dados estatisticamente significativos em relação a associação às doenças estudadas, apenas em relação ao SNP TLR2-rs4696480.

Este SNP foi previamente relacionado, a partir da pesquisa de dados publicados na literatura em relação às neoplasias malignas, ao desenvolvimento de alguns tipos de linfomas em população alemã (113); porém não foi associado ao desenvolvimento de hepatocarcinoma em pacientes com hepatite $C$ também em população alemã (114). No que diz respeito a doenças imuno-mediadas, tais como o LPO, foi relacionado à asma infantil em crianças expostas à poluição do ar em população holandesa (115), mas não mostrou associação à artrite reumatóide em população francesa (116).

Em relação à amostra estudada, cuja população é originária do País Basco (Espanha), a presença do alelo mutado A do SNP TLR2-rs4696480 foi relacionada significativamente ao risco aumentado de desenvolvimento de CEC de boca ( $p=$ 0,033). Indivíduos com o genótipo heterozigoto AT apresentaram risco aumentado de desenvolver CEC de boca em cinco vezes, quando comparados àqueles com o genótipo selvagem TT, enquanto aqueles com o genótipo homozigoto mutado AA apresentaram o risco aumentado em sete vezes (ver Tabela 5.2); suportando a possível relação deste SNP e o risco de desenvolvimento de CEC de boca. 
Entretanto, a presença do alelo mutado A em $85 \%$ dos pacientes acometidos por CEC de boca não esteve relacionada aos hábitos de tabaco e álcool destes pacientes $(p>0.05)$; tampouco a presença de metástases em linfonodos regionais e tumores em estágios avançados $(p>0.05)$, apesar de estes estarem presentes apenas em indivíduos com o genótipo AA e AT, possivelmente pelo pequeno tamanho da amostra de indivíduos com genótipo selvagem (ver Tabela 5.5).

Vale ressaltar que nesta análise, $17.5 \%$ dos casos de CEC de boca estavam localizados em orofaringe. Atualmente costuma-se analisar este tipo de tumor isoladamente em decorrência de diferenças na etiologia deste tumor em relação a esta localização específica (orofaringe) e a relação com a infecção com HPV (117). Entretanto, no presente estudo pelo reduzido tamanho da amostra esta comparação entre o CEC de orofaringe e o CEC de outras localizações na cavidade bucal não foi possível. Embora evidências recentes apontem inclusive a interação entre a infecção pelo HPV e os receptores estudados, os TLR, principalmente em estudos com câncer cervical (118).

Tendo em vista que as LLO apresentam maior relação com a possível transformação maligna da lesão oral liquenóide, a presença do alelo mutado $A$ para o SNP TLR2-rs4696480 foi avaliada separadamente em relação às formas de DLO, LPO idiopático e LLO, devido à alta frequência dos genótipos mutantes (AT-49.1\%, AA-29.1\%), porém não estatisticamente significativa $(p=0.063)$ nesta primeira análise.

Uma segunda análise, discriminando pacientes com LPO idiopático e LLO, permitiu observar relação significativa da frequência do alelo mutado em ambos os grupos em relação ao grupo controle, especialmente em relação à frequência de indivíduos heterozigotos ( $p=0.045$ e $p=0.0003$, respectivamente). Mais ainda, foi possível relacionar significativamente o risco do desenvolvimento de LLO e a presença do alelo mutado A do SNP TLR2-rs4696480 ( $p=0.0223)$. Indivíduos com genótipo heterozigoto AT apresentam risco aumentado em 5 vezes de desenvolver LLO em comparação ao genótipo selvagem TT e indivíduos com o genótipo homozigoto mutado AA apresentam risco aumentado em 4 vezes de desenvolver LLO. Esta mesma relação de risco não foi observada entre os pacientes com LPO idiopático (ver tabela 5.6), embora frequentemente observado neste grupo.

Desta forma, a herança deste SNP do TLR2 parece estar relacionada a um maior risco de desenvolvimento de desordem oral potencialmente maligna (LPO) e 
do câncer de boca (CEC de boca). A expressão do TLR2 parece estar diminuída no LPO $(9,10)$, em contrapartida parece estar aumentada nas células de CEC de boca, sendo ainda correlacionada com a inibição da apoptose (77-79), fato este que está relacionado à alta expressão do TLR4 no LPO (64). Estas diferenças podem estar relacionadas à associação das funções dos TLR nestas doenças, ou devido ao escasso número de amostras analisadas e de investigações deste gênero, sendo necessária a realização de estudos adicionais a fim de identificar a função de cada um destes receptores.

Não foram encontradas outras investigações publicadas a respeito deste ou de outros SNP no gene do TLR2 tanto pacientes com LPO quanto em indivíduos com CEC de boca. Os resultados do presente estudo revelaram que o SNP TLR2rs4696480 está possivelmente relacionado com a predisposição ao desenvolvimento de lesão bucal maligna, visto que esteve associado significativamente a indivíduos com CEC de boca, e indivíduos com lesão bucal com potencial de transformação maligna, LLO. Desta forma, é necessário o aprofundamento no estudo da proteína codificada por este gene mutado, suas consequências e relação com estas doenças; bem como a associação da herança deste mesmo SNP, bem como SNP em outros TLR, e outras condições bucais com potencial de transformação maligna.

Quanto aos SNP em TLR e o CEC de laringe, apenas foi observada relação significativa em relação à maior frequência dos genótipos com alelo mutante, especialmente heterozigotos, dos SNP TLR4-rs1927911 (AG-54.3\%, $p=0.018$ ) e TLR9-rs352139 (CT-60\%, $p=0.046$ ). No entanto esses SNP estavam relacionados ao risco aumentado de desenvolvimento de CEC de laringe, provavelmente devido ao pequeno tamanho da amostra incluída deste grupo de pacientes $(n=35)$ (ver Tabelas 5.3 e 5.4).

De qualquer maneira a relação destes receptores merece atenção no CEC de laringe, visto que o TLR4 apresenta escassa expressão nos tumores pouco diferenciados, relacionando este receptor ao grau de agressividade do tumor. Dessa forma, o TLR4 poderia servir futuramente como um biomarcador para proliferação do tumor e da agressividade $(87,88)$. E o TLR9, por sua vez, apresenta intensa expressão em linhagens de células em cultura de CEC de laringe, tanto gênica quanto proteica, e este receptor estaria possivelmente relacionado ao crescimento tumoral (89). 
Diversos estudos sugerem que a variação genética em TLR possa alterar a susceptibilidade a doenças infecciosas e não infecciosas. A herança de SNP relacionados em seu conjunto pode levar ao desenvolvimento de doenças multifatoriais, mesmo aquelas com componente ambiental forte, tal como o câncer (119). Entretanto, dados os complexos padrões de herança poligênica, o impacto de um único alelo na susceptibilidade a uma doença (penetrância) é muitas vezes modesto. Os estudos, mais convincentes, de associação de SNP a doenças com padrão de herança complexo incluem amostras de grande tamanho, ajustes estatísticos para comparação múltipla, replicação de resultados em grupos independentes, projetos de múltiplos estudos (incluindo caso-controle e coorte), ajuste da análise pela combinação de diferentes populações (7).

Desde que os TLR estão no foco do desenvolvimento de diversas terapias moleculares, pela indústria farmacêutica para outros tipos de neoplasia maligna, o aprofundamento da investigação do papel dos TLR nas desordens orais com potencial de transformação maligna e no câncer de boca é encorajado, buscando uma futura relação de atuação dos TLR como marcadores do comportamento tumoral ou como alvo de terapias específicas. 


\section{CONCLUSÕES}

1. O SNP TLR2-rs4696480 parece estar relacionado à suscetibilidade de desenvolvimento de LLO e de CEC de boca na população estudada.

2. Os SNP TLR4-rs1927911 e TLR9-rs352139 foram encontrados com significativa frequência em pacientes com CEC de laringe, mas não foram relacionados à predisposição deste.

3. Os SNP TLR1-rs4833095, TLR1-rs5743618, TLR4-rs1927911, TLR6rs5743810, TLR9-rs352139, TLR9-rs5743836, TLR10-rs11096957 parecem não estar relacionados ao risco de desenvolvimento de LPO, CEC de boca e CEC de laringe na população estudada.

4. Estudos envolvendo pacientes com LPO devem considerar a estratificação dos pacientes com lesões atípicas, LLO.

5. Tendo em vista a revisão de literatura e os resultados obtidos, é possível que polimorfismos nos TLR participem nos processos de desenvolvimento de lesões malignas e com potencial de transformação maligna, suportando o seguimento e detalhamento de pesquisas nesse campo. 


\section{REFERÊNCIAS ${ }^{10}$}

1 Pasare C, Medzhitov R. Toll-like receptors: linking innate and adaptive immunity. Adv Exp Med Biol. 2005;560:11-8.

2 Beutler BA. TLRs and innate immunity. Blood. 2009 Feb;113(7):1399-407.

3 Arancibia SA, Beltrán CJ, Aguirre IM, Silva P, Peralta AL, Malinarich F, et al. Toll-like receptors are key participants in innate immune responses. Biol Res. 2007;40(2):97-112.

4 Brown J, Wang $\mathrm{H}$, Hajishengallis GN, Martin M. TLR-signaling networks: an integration of adaptor molecules, kinases, and cross-talk. J Dent Res. 2011 Apr;90(4):417-27.

5 Liu H, Komai-Koma M, Xu D, Liew FY. Toll-like receptor 2 signaling modulates the functions of CD4+ CD25+ regulatory T cells. Proc Natl Acad Sci U S A. 2006 May 2;103(18):7048-53.

$6 \quad$ Kim S, Karin M. Role of TLR2-dependent inflammation in metastatic progression. Ann N Y Acad Sci. 2011 Jan;1217:191-206.

7 Misch EA, Hawn TR. Toll-like receptor polymorphisms and susceptibility to human disease. Clin Sci (Lond). 2008 Mar;114(5):347-60.

8 Siponen M, Kauppila JH, Soini Y, Salo T. TLR4 and TLR9 are induced in oral lichen planus. J Oral Pathol Med. 2012 Jun.

9 Janardhanam SB, Prakasam S, Swaminathan VT, Kodumudi KN, Zunt SL, Srinivasan M. Differential expression of TLR-2 and TLR-4 in the epithelial cells in oral lichen planus. Arch Oral Biol. 2012 May;57(5):495-502.

10 Srinivasan M, Kodumudi KN, Zunt SL. Soluble CD14 and toll-like receptor-2 are potential salivary biomarkers for oral lichen planus and burning mouth syndrome. Clin Immunol. 2008 Jan;126(1):31-7.

\footnotetext{
${ }^{10}$ De acordo com Estilo Vancouver
} 
11 Li J, Chen J, Tan Z, Liu H, Liu Z. Expression of TLR9 and its mRNA in the lesions of lichen planus. J Huazhong Univ Sci Technolog Med Sci. 2007 Apr;27(2):203-5.

12 Ohno S, Tateishi Y, Tatemoto Y, Morishita K, Sasabe E, Yamamoto T. Enhanced expression of Toll-like receptor 2 in lesional tissues and peripheral blood monocytes of patients with oral lichen planus. J Dermatol. 2011 Apr;38(4):335-44.

13 Zhou XJ, Sugerman PB, Savage NW, Walsh LJ, Seymour GJ. Intra-epithelial CD8+ T cells and basement membrane disruption in oral lichen planus. J Oral Pathol Med. 2002 Jan;31(1):23-7.

14 Sugerman PB, Savage NW, Walsh LJ, Zhao ZZ, Zhou XJ, Khan A, et al. The pathogenesis of oral lichen planus. Crit Rev Oral Biol Med. 2002;13(4):350-65.

15 Cortés-Ramírez DA, Gainza-Cirauqui ML, Echebarria-Goikouria MA, AguirreUrizar JM. Oral lichenoid disease as a premalignant condition: the controversies and the unknown. Med Oral Patol Oral Cir Bucal. 2009 Mar;14(3):E118-22.

16 Georgakopoulou EA, Achtari MD, Achtaris M, Foukas PG, Kotsinas A. Oral lichen planus as a preneoplastic inflammatory model. J Biomed Biotechnol. 2012;2012:759626.

17 Lodi G, Scully C, Carrozzo M, Griffiths M, Sugerman PB, Thongprasom K. Current controversies in oral lichen planus: report of an international consensus meeting. Part 2. Clinical management and malignant transformation. Oral Surg Oral Med Oral Pathol Oral Radiol Endod. 2005 Aug;100(2):164-78.

18 Bergmann C, Bachmann HS, Bankfalvi A, Lotfi R, Pütter C, Wild CA, et al. Toll-like receptor 4 single-nucleotide polymorphisms Asp299Gly and Thr399lle in head and neck squamous cell carcinomas. J Transl Med. 2011;9:139.

19 Chuang HC, Huang CC, Chien CY, Chuang JH. Toll-like receptor 3-mediated tumor invasion in head and neck cancer. Oral Oncol. 2012 Mar;48(3):226-32.

$20 \mathrm{Yu}$ L, Chen S. Toll-like receptors expressed in tumor cells: targets for therapy. Cancer Immunol Immunother. 2008 Sep;57(9):1271-8.

21 So EY, Ouchi T. The application of Toll like receptors for cancer therapy. Int $\mathrm{J}$ Biol Sci. 2010;6(7):675-81. 
22 Huang B, Zhao J, Unkeless JC, Feng ZH, Xiong $\mathrm{H}$. TLR signaling by tumor and immune cells: a double-edged sword. Oncogene. 2008 Jan;27(2):218-24.

23 Oblak A, Jerala $\mathrm{R}$. Toll-like receptor 4 activation in cancer progression and therapy. Clin Dev Immunol. 2011;2011:609579.

24 van der Meij $\mathrm{EH}$, Mast $\mathrm{H}$, van der Waal I. The possible premalignant character of oral lichen planus and oral lichenoid lesions: a prospective five-year follow-up study of 192 patients. Oral Oncol. 2007 Sep;43(8):742-8.

25 Warnakulasuriya S, Kovacevic T, Madden P, Coupland VH, Sperandio M, Odell E, et al. Factors predicting malignant transformation in oral potentially malignant disorders among patients accrued over a 10-year period in South East England. J Oral Pathol Med. 2011 Jul.

26 Gonzalez-Moles MA, Scully C, Gil-Montoya JA. Oral lichen planus: controversies surrounding malignant transformation. Oral Dis. 2008 Apr;14(3):22943.

27 Pace E, Ferraro M, Siena L, Melis M, Montalbano AM, Johnson M, et al. Cigarette smoke increases Toll-like receptor 4 and modifies lipopolysaccharidemediated responses in airway epithelial cells. Immunology. 2008 Jul;124(3):401-11.

28 Goldstein DB, Cavalleri GL. Genomics: understanding human diversity. Nature. 2005 Oct;437(7063):1241-2.

29 Ségurel L, Thompson EE, Flutre T, Lovstad J, Venkat A, Margulis SW, et al. The ABO blood group is a trans-species polymorphism in primates. Proc Natl Acad Sci U S A. 2012 Nov;109(45):18493-8.

30 Llaurens V, Raymond M, Faurie C. Why are some people left-handed? An evolutionary perspective. Philos Trans R Soc Lond B Biol Sci. 2009 Apr;364(1519):881-94.

31 Bianch FJ, de Oliveira TF, Saito CB, Peres RC, Line SR. Association between polymorphism in the promoter region (G/C-915) of PAX9 gene and third molar agenesis. J Appl Oral Sci. 2007 Oct;15(5):382-6.

32 Hansson GK, Edfeldt K. Toll to be paid at the gateway to the vessel wall. Arterioscler Thromb Vasc Biol. 2005 Jun;25(6):1085-7. 
33 Anderson KV, Bokla L, Nüsslein-Volhard C. Establishment of dorsal-ventral polarity in the Drosophila embryo: the induction of polarity by the Toll gene product. Cell. 1985 Oct;42(3):791-8.

34 Gay NJ, Keith FJ. Drosophila Toll and IL-1 receptor. Nature. 1991 May;351(6325):355-6.

35 Lemaitre B, Nicolas E, Michaut L, Reichhart JM, Hoffmann JA. The dorsoventral regulatory gene cassette spätzle/Toll/cactus controls the potent antifungal response in Drosophila adults. Cell. 1996 Sep;86(6):973-83.

36 Medzhitov R, Preston-Hurlburt P, Janeway CA. A human homologue of the Drosophila Toll protein signals activation of adaptive immunity. Nature. 1997 Jul;388(6640):394-7.

37 Poltorak A, He X, Smirnova I, Liu MY, Van Huffel C, Du X, et al. Defective LPS signaling in $\mathrm{C} 3 \mathrm{H} / \mathrm{HeJ}$ and $\mathrm{C} 57 \mathrm{BL} / 10 \mathrm{ScCr}$ mice: mutations in TIr4 gene. Science. 1998 Dec;282(5396):2085-8.

38 Poltorak A, Smirnova I, He X, Liu MY, Van Huffel C, McNally O, et al. Genetic and physical mapping of the Lps locus: identification of the toll-4 receptor as a candidate gene in the critical region. Blood Cells Mol Dis. 1998 Sep;24(3):340-55.

39 Nomura N, Miyajima N, Sazuka T, Tanaka A, Kawarabayasi Y, Sato S, et al. Prediction of the coding sequences of unidentified human genes. I. The coding sequences of 40 new genes (KIAA0001-KIAA0040) deduced by analysis of randomly sampled cDNA clones from human immature myeloid cell line KG-1 (supplement). DNA Res. 1994;1(1):47-56.

40 Taguchi T, Mitcham JL, Dower SK, Sims JE, Testa JR. Chromosomal localization of TIL, a gene encoding a protein related to the Drosophila transmembrane receptor Toll, to human chromosome 4p14. Genomics. 1996 Mar;32(3):486-8.

41 Holmes D. Nobel prize for medicine marred by death and controversy. Lancet. 2011 Oct;378(9800):1367.

42 Botos I, Segal DM, Davies DR. The structural biology of Toll-like receptors. Structure. 2011 Apr;19(4):447-59. 
43 Yamamoto M, Takeda K. Current views of toll-like receptor signaling pathways. Gastroenterol Res Pract. 2010;2010:240365.

44 Lodi G, Scully C, Carrozzo M, Griffiths M, Sugerman PB, Thongprasom K. Current controversies in oral lichen planus: report of an international consensus meeting. Part 1. Viral infections and etiopathogenesis. Oral Surg Oral Med Oral Pathol Oral Radiol Endod. 2005 Jul;100(1):40-51.

45 Nico MM, Fernandes JD, Lourenço SV. Oral lichen planus. An Bras Dermatol. 20112011 Jul-Aug;86(4):633-41; quiz 42-3.

46 Machado AC, Sugaya NN, Migliari DA, Matthews RW. Oral lichen planus. Clinical aspects and management in fifty-two Brazilian patients. West Indian Med J. 2004 Mar;53(2):113-7.

47 Scully C, Beyli M, Ferreiro MC, Ficarra G, Gill Y, Griffiths M, et al. Update on oral lichen planus: etiopathogenesis and management. Crit Rev Oral Biol Med. 1998;9(1):86-122.

48 Carrozzo M, Gandolfo S. The management of oral lichen planus. Oral Dis. 1999 Jul;5(3):196-205.

49 van der Meij EH, van der Waal I. Lack of clinicopathologic correlation in the diagnosis of oral lichen planus based on the presently available diagnostic criteria and suggestions for modifications. J Oral Pathol Med. 2003 Oct;32(9):507-12.

50 Aguirre Urizar JM. Letter to the editor: oral lichenoid disease. A new classification proposal. Med Oral Patol Oral Cir Bucal. 2008 Apr;13(4):E224.

51 Klanrit P, Sperandio M, Brown AL, Shirlaw PJ, Challacombe SJ, Morgan PR, et al. DNA ploidy in proliferative verrucous leukoplakia. Oral Oncol. 2007 Mar;43(3):310-6.

52 Diwakar N, Sperandio M, Sherriff M, Brown A, Odell EW. Heterogeneity, histological features and DNA ploidy in oral carcinoma by image-based analysis. Oral Oncol. 2005 Apr;41(4):416-22.

53 Acha-Sagredo A, Jiménez Y, Bagán JV, Echebarria-Goicouria MA, AguirreUrizar JM. Cytometric analysis of oral scrapings of patients with oral lichen planus. Cytopathology. 2011 Apr;22(2):106-10. 
54 Mattsson U, Jontell M, Holmstrup P. Oral lichen planus and malignant transformation: is a recall of patients justified? Crit Rev Oral Biol Med.

2002;13(5):390-6.

55 Liu Y, Messadi DV, Wu H, Hu S. Oral lichen planus is a unique disease model for studying chronic inflammation and oral cancer. Med Hypotheses. 2010 Dec;75(6):492-4.

56 Thornhill MH, Pemberton MN, Simmons RK, Theaker ED. Amalgam-contact hypersensitivity lesions and oral lichen planus. Oral Surg Oral Med Oral Pathol Oral Radiol Endod. 2003 Mar;95(3):291-9.

57 Carrozzo M, Gandolfo S, Lodi G, Carbone M, Garzino-Demo P, Carbonero C, et al. Oral lichen planus in patients infected or noninfected with hepatitis $C$ virus: the role of autoimmunity. J Oral Pathol Med. 1999 Jan;28(1):16-9.

58 Lodi G, Porter SR. Hepatitis C virus infection and lichen planus: a short review. Oral Dis. 1997 Jun;3(2):77-81.

59 Roopashree MR, Gondhalekar RV, Shashikanth MC, George J, Thippeswamy $\mathrm{SH}$, Shukla A. Pathogenesis of oral lichen planus--a review. J Oral Pathol Med. 2010 Nov;39(10):729-34.

60 Bagan JV, Donat JS, Penarrocha M, Milian MA, Sanchis JM. Oral lichen planus and diabetes mellitus. A clinico-pathological study. Bull Group Int Rech Sci Stomatol Odontol. 19931993 Mar-Jun;36(1-2):3-6.

61 Eisen D, Carrozzo M, Bagan Sebastian JV, Thongprasom K. Number V Oral lichen planus: clinical features and management. Oral Dis. 2005 Nov;11(6):338-49.

62 lijima W, Ohtani H, Nakayama T, Sugawara Y, Sato E, Nagura H, et al. Infiltrating CD8+ T cells in oral lichen planus predominantly express CCR5 and CXCR3 and carry respective chemokine ligands RANTES/CCL5 and IP-10/CXCL10 in their cytolytic granules: a potential self-recruiting mechanism. Am J Pathol. 2003 Jul;163(1):261-8.

63 Lang KS, Recher M, Junt T, Navarini AA, Harris NL, Freigang S, et al. Toll-like receptor engagement converts $\mathrm{T}$-cell autoreactivity into overt autoimmune disease. Nat Med. 2005 Feb;11(2):138-45. 
64 Ge Y, Xu Y, Sun W, Man Z, Zhu L, Xia X, et al. The molecular mechanisms of the effect of Dexamethasone and Cyclosporin A on TLR4 /NF-KB signaling pathway activation in oral lichen planus. Gene. 2012 Oct;508(2):157-64.

65 El Tawdy A, Rashed L. Downregulation of TLR-7 receptor in hepatic and nonhepatic patients with lichen planus. Int J Dermatol. 2012 Jul;51(7):785-9.

66 Salem SA, Abu-Zeid RM, Nada OH. Immunohistochemical study of toll-like receptors 1 and 2 expression in cutaneous lichen planus lesions. Arch Dermatol Res. 2012 Jul.

67 Schmidt C. Immune system's Toll-like receptors have good opportunity for cancer treatment. J Natl Cancer Inst. 2006 May;98(9):574-5.

68 Kutikhin AG. Association of polymorphisms in TLR genes and in genes of the Toll-like receptor signaling pathway with cancer risk. Hum Immunol. 2011 Nov;72(11):1095-116.

69 Hirsch I, Caux C, Hasan U, Bendriss-Vermare N, Olive D. Impaired Toll-like receptor 7 and 9 signaling: from chronic viral infections to cancer. Trends Immunol. 2010 Oct;31(10):391-7.

70 Marichalar-Mendia X, Rodriguez-Tojo MJ, Acha-Sagredo A, Rey-Barja N, Aguirre-Urizar JM. Oral cancer and polymorphism of ethanol metabolising genes. Oral Oncol. 2010 Jan;46(1):9-13.

71 Warnakulasuriya S. Global epidemiology of oral and oropharyngeal cancer. Oral Oncol. 20092009 Apr-May;45(4-5):309-16.

72 Warnakulasuriya S. Causes of oral cancer--an appraisal of controversies. $\mathrm{Br}$ Dent J. 2009 Nov;207(10):471-5.

73 Jeon GA, Lee JS, Patel V, Gutkind JS, Thorgeirsson SS, Kim EC, et al. Global gene expression profiles of human head and neck squamous carcinoma cell lines. Int J Cancer. 2004 Nov;112(2):249-58.

74 Epstein JB, Zhang L, Rosin M. Advances in the diagnosis of oral premalignant and malignant lesions. J Can Dent Assoc. 2002 Nov;68(10):617-21. 
75 Mehrotra R, Yadav S. Oral squamous cell carcinoma: etiology, pathogenesis and prognostic value of genomic alterations. Indian J Cancer. 20062006 AprJun;43(2):60-6.

76 Mizumachi T, Kano S, Sakashita T, Hatakeyama H, Suzuki S, Homma A, et al. Improved survival of Japanese patients with human papillomavirus-positive oropharyngeal squamous cell carcinoma. Int J Clin Oncol. 2012 Aug.

77 Ng LK, Rich AM, Hussaini HM, Thomson WM, Fisher AL, Horne LS, et al. Tolllike receptor 2 is present in the microenvironment of oral squamous cell carcinoma. Br J Cancer. 2011 Feb;104(3):460-3.

78 Szczepański M, Stelmachowska M, Stryczyński L, Golusiński W, Samara H, Mozer-Lisewska I, et al. Assessment of expression of toll-like receptors 2, 3 and 4 in laryngeal carcinoma. Eur Arch Otorhinolaryngol. 2007 May;264(5):525-30.

79 Nomi N, Kodama S, Suzuki M. Toll-like receptor 3 signaling induces apoptosis in human head and neck cancer via survivin associated pathway. Oncol Rep. 2010 Jul;24(1):225-31.

80 Rydberg C, Månsson A, Uddman R, Riesbeck K, Cardell LO. Toll-like receptor agonists induce inflammation and cell death in a model of head and neck squamous cell carcinomas. Immunology. 2009 Sep;128(1 Suppl):e600-11.

81 Park JH, Yoon HE, Jeon DI, Ahn SG, Yoon JH. Activation of TLR2 and TLR5 did not affect tumor progression of an oral squamous cell carcinoma, YD-10B cells. $J$ Oral Pathol Med. 2010 Nov;39(10):781-5.

82 Pries R, Hogrefe L, Xie L, Frenzel H, Brocks C, Ditz C, et al. Induction of CMyc-dependent cell proliferation through toll-like receptor 3 in head and neck cancer. Int J Mol Med. 2008 Feb;21(2):209-15.

83 Sheyhidin I, Nabi G, Hasim A, Zhang RP, Ainiwaer J, Ma H, et al. Overexpression of TLR3, TLR4, TLR7 and TLR9 in esophageal squamous cell carcinoma. World J Gastroenterol. 2011 Aug;17(32):3745-51.

84 Zhang $Y$, Sun R, Liu B, Deng M, Zhang W, Li Y, et al. TLR3 activation inhibits nasopharyngeal carcinoma metastasis via downregulation of chemokine receptor CXCR4. Cancer Biol Ther. 2009 Oct;8(19):1826-30. 
85 Chan VS, Tsao SW, Lin CL. Toll prevents a move. Cancer Biol Ther. 2009 Oct;8(19):1838-9.

86 Umemura N, Zhu J, Mburu YK, Forero A, Hsieh PN, Muthuswamy R, et al. Defective NF-KB signaling in metastatic head and neck cancer cells leads to enhanced apoptosis by double-stranded RNA. Cancer Res. 2012 Jan;72(1):45-55.

87 Szczepanski MJ, Czystowska M, Szajnik M, Harasymczuk M, Boyiadzis M, Kruk-Zagajewska $A$, et al. Triggering of Toll-like receptor 4 expressed on human head and neck squamous cell carcinoma promotes tumor development and protects the tumor from immune attack. Cancer Res. 2009 Apr;69(7):3105-13.

88 Starska K, Forma E, Lewy-Trenda I, Stasikowska O, Bryś M, Krajewska WM, et al. The expression of SOCS1 and TLR4-NFkappaB pathway molecules in neoplastic cells as potential biomarker for the aggressive tumor phenotype in laryngeal carcinoma. Folia Histochem Cytobiol. 2009 Jan;47(3):401-10.

89 Sikora J, Frydrychowicz M, Kaczmarek M, Brzezicha B, Mozer-Lisewska I, Szczepański M, et al. TLR receptors in laryngeal carcinoma - immunophenotypic, molecular and functional studies. Folia Histochem Cytobiol. 2010 Dec;48(4):624-31.

90 Min R, Zun Z, Siyi L, Wenjun Y, Lizheng W, Chenping Z. Increased expression of Toll-like receptor-9 has close relation with tumour cell proliferation in oral squamous cell carcinoma. Arch Oral Biol. 2011 Sep;56(9):877-84.

91 Kauppila JH, Takala H, Selander KS, Lehenkari PP, Saarnio J, Karttunen TJ. Increased Toll-like receptor 9 expression indicates adverse prognosis in oesophageal adenocarcinoma. Histopathology. 2011 Oct;59(4):643-9.

92 Pries R, Wulff S, Kesselring R, Börngen K, Xie L, Wollenberg B. Up-regulation of NK cell function against head and neck cancer in response to ss-isRNA requires TLR7. Int J Oncol. 2008 Nov;33(5):993-1000.

93 Xie L, Pries R, Kesselring R, Wulff S, Wollenberg B. Head and neck cancer triggers the internalization of TLR3 in natural killer cells. Int J Mol Med. 2007 Oct;20(4):493-9.

94 He JF, Jia WH, Fan Q, Zhou XX, Qin HD, Shugart YY, et al. Genetic polymorphisms of TLR3 are associated with Nasopharyngeal carcinoma risk in Cantonese population. BMC Cancer. 2007;7:194. 
95 Yang ZH, Dai Q, Gu YJ, Guo QX, Gong L. Cytokine and chemokine modification by Toll-like receptor polymorphisms is associated with nasopharyngeal carcinoma. Cancer Sci. 2012 Apr;103(4):653-8.

96 Aldred MA, Eng C. SNP'ing at nasopharyngeal cancer susceptibility: for whom the bell TOLLs. Cancer Biol Ther. 2006 Oct;5(10):1292-3.

97 Song C, Chen LZ, Zhang RH, Yu XJ, Zeng YX. Functional variant in the 3'untranslated region of Toll-like receptor 4 is associated with nasopharyngeal carcinoma risk. Cancer Biol Ther. 2006 Oct;5(10):1285-91.

98 Zhou XX, Jia WH, Shen GP, Qin HD, Yu XJ, Chen LZ, et al. Sequence variants in toll-like receptor 10 are associated with nasopharyngeal carcinoma risk. Cancer Epidemiol Biomarkers Prev. 2006 May;15(5):862-6.

99 Rad M, Hashemipoor MA, Mojtahedi A, Zarei MR, Chamani G, Kakoei S, et al. Correlation between clinical and histopathologic diagnoses of oral lichen planus based on modified WHO diagnostic criteria. Oral Surg Oral Med Oral Pathol Oral Radiol Endod. 2009 Jun;107(6):796-800.

100 Petersen PE. Oral cancer prevention and control--the approach of the World Health Organization. Oral Oncol. 20092009 Apr-May;45(4-5):454-60.

101 Gorlov IP, Gorlova OY, Sunyaev SR, Spitz MR, Amos CI. Shifting paradigm of association studies: value of rare single-nucleotide polymorphisms. Am J Hum Genet. 2008 Jan;82(1):100-12.

102 Carlson CS, Eberle MA, Rieder MJ, Yi Q, Kruglyak L, Nickerson DA. Selecting a maximally informative set of single-nucleotide polymorphisms for association analyses using linkage disequilibrium. Am J Hum Genet. 2004 Jan;74(1):106-20.

103 Lange NE, Zhou X, Lasky-Su J, Himes BE, Lazarus R, Soto-Quirós M, et al. Comprehensive genetic assessment of a functional TLR9 promoter polymorphism: no replicable association with asthma or asthma-related phenotypes. BMC Med Genet. 2011;12:26.

104 Eickbush TH. Molecular biology. Introns gain ground. Nature. 2000 Apr;404(6781):940-1, 3. 
105 Fakhrai-Rad H, Pourmand N, Ronaghi M. Pyrosequencing: an accurate detection platform for single nucleotide polymorphisms. Hum Mutat. 2002 May;19(5):479-85.

106 Ronaghi M. Pyrosequencing sheds light on DNA sequencing. Genome Res. 2001 Jan;11(1):3-11.

107 Ahn MY, Kwon SM, Cheong HH, Park JH, Lee J, Min SK, et al. Toll-like receptor 7 agonist, Imiquimod, inhibits oral squamous carcinoma cells through apoptosis and necrosis. J Oral Pathol Med. 2012 May.

108 Izarzugaza MI, Esparza H, Aguirre JM. Epidemiological aspects of oral and pharyngeal cancers in the Basque Country. J Oral Pathol Med. 2001 Oct;30(9):521-6.

109 Wight AJ, Ogden GR. Possible mechanisms by which alcohol may influence the development of oral cancer--a review. Oral Oncol. 1998 Nov;34(6):441-7.

110 Dedivitis RA, França CM, Mafra ACB, Guimarães FT, Guimarães AV. Características clínico-epidemiológicas no carcinoma espinocelular de boca e orofaringe. Revista Brasileira de Otorrinolaringologia. 2004;70:35-40.

111 Santos LC, Batista OeM, Cangussu MC. Characterization of oral cancer diagnostic delay in the state of Alagoas. Braz J Otorhinolaryngol. $20102010 \mathrm{Jul}-$ Aug;76(4):416-22.

112 Kowalski LP, Franco EL, Torloni H, Fava AS, de Andrade Sobrinho J, Ramos $\mathrm{G}$, et al. Lateness of diagnosis of oral and oropharyngeal carcinoma: factors related to the tumour, the patient and health professionals. Eur J Cancer B Oral Oncol. 1994 May;30B(3):167-73.

113 Nieters A, Beckmann L, Deeg E, Becker N. Gene polymorphisms in Toll-like receptors, interleukin-10, and interleukin-10 receptor alpha and lymphoma risk.

Genes Immun. 2006 Dec;7(8):615-24.

114 Nischalke HD, Coenen M, Berger C, Aldenhoff K, Müller T, Berg T, et al. The toll-like receptor 2 (TLR2) -196 to -174 del/ins polymorphism affects viral loads and susceptibility to hepatocellular carcinoma in chronic hepatitis C. Int J Cancer. 2012 Mar;130(6):1470-5. 
115 Kerkhof M, Postma DS, Brunekreef B, Reijmerink NE, Wijga AH, de Jongste $\mathrm{JC}$, et al. Toll-like receptor 2 and 4 genes influence susceptibility to adverse effects of traffic-related air pollution on childhood asthma. Thorax. 2010 Aug;65(8):690-7.

116 Jaen O, Petit-Teixeira E, Kirsten H, Ahnert P, Semerano L, Pierlot C, et al. No evidence of major effects in several Toll-like receptor gene polymorphisms in rheumatoid arthritis. Arthritis Res Ther. 2009;11(1):R5.

117 El-Naggar AK, Westra WH. p16 expression as a surrogate marker for HPVrelated oropharyngeal carcinoma: a guide for interpretative relevance and consistency. Head Neck. 2012 Apr;34(4):459-61.

118 Domingos-Pereira S, Decrausaz L, Derré L, Bobst M, Romero P, Schiller JT, et al. Intravaginal TLR agonists increase local vaccine-specific CD8 T cells and human papillomavirus-associated genital-tumor regression in mice. Mucosal Immunol. 2012 Sep.

119 El-Omar EM, Ng MT, Hold GL. Polymorphisms in Toll-like receptor genes and risk of cancer. Oncogene. 2008 Jan;27(2):244-52. 
APÊNDICE A - Resultados da validação dos ensaios $\operatorname{TaqMan}^{\circledR}$

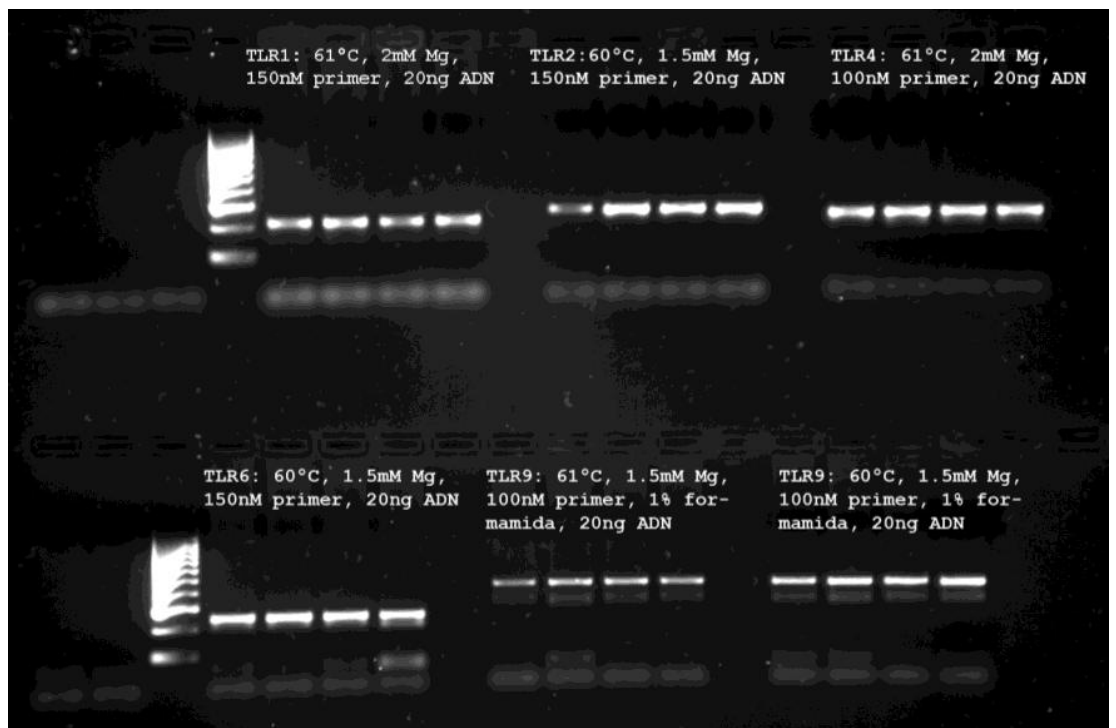

Figura A.1 - Resultados considerados adequados observados em gel de agarose $1.5 \%$ do PCR convencional de amostras de DNA-teste com os iniciadores desenhados para a validação dos ensaios $\operatorname{TaqMan}^{\circledR}$ para genotipagem submetidos então ao sequenciamento do DNA (condições descritas na Tabela 4.3)

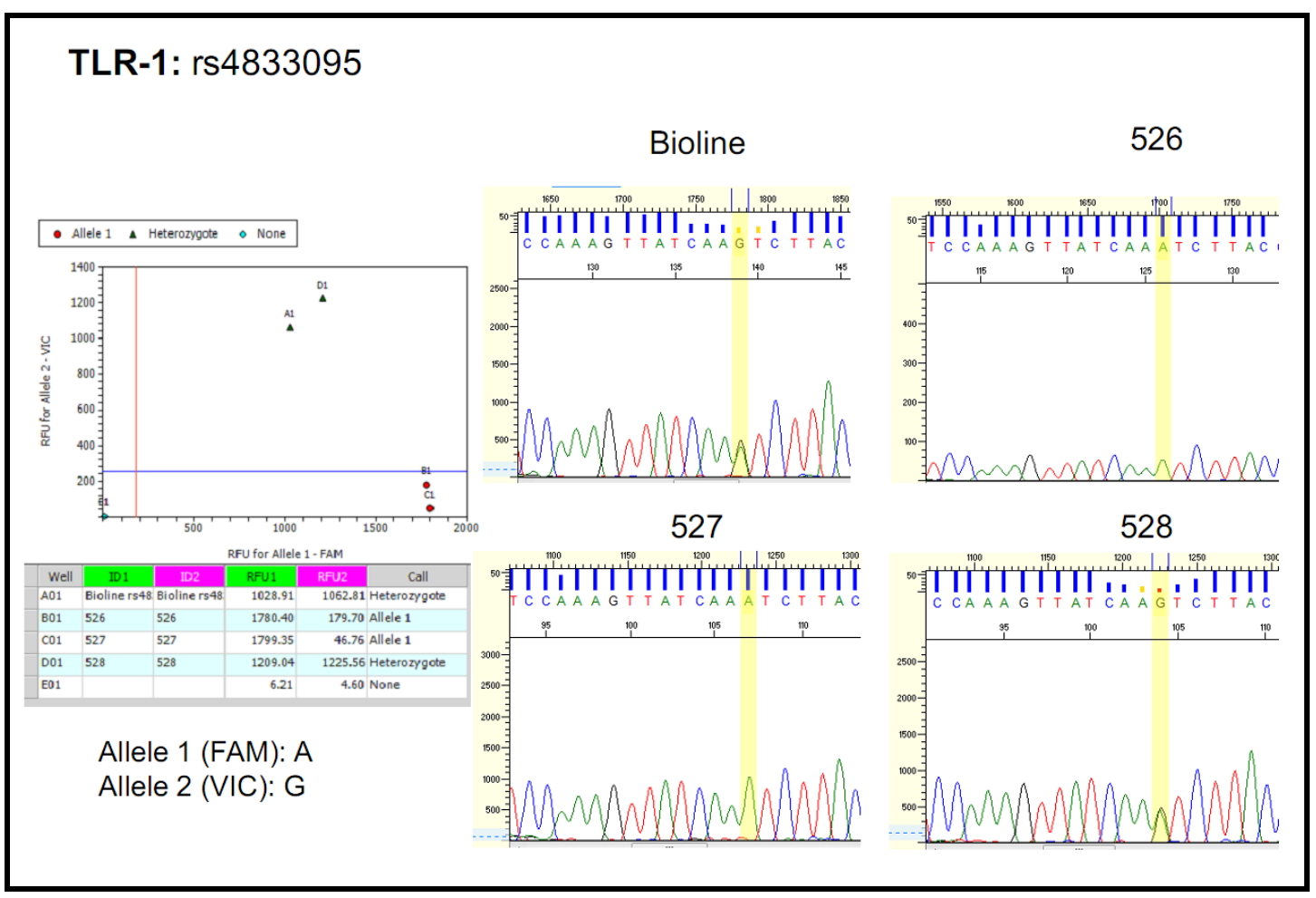

Figura A.2 - Resultados da comparação dos resultados de ensaio TaqMan ${ }^{\circledR}$ aos do sequenciamento com a validação do ensaio TaqMan ${ }^{\circledR}$ para o SNP TLR1-rs4833095 


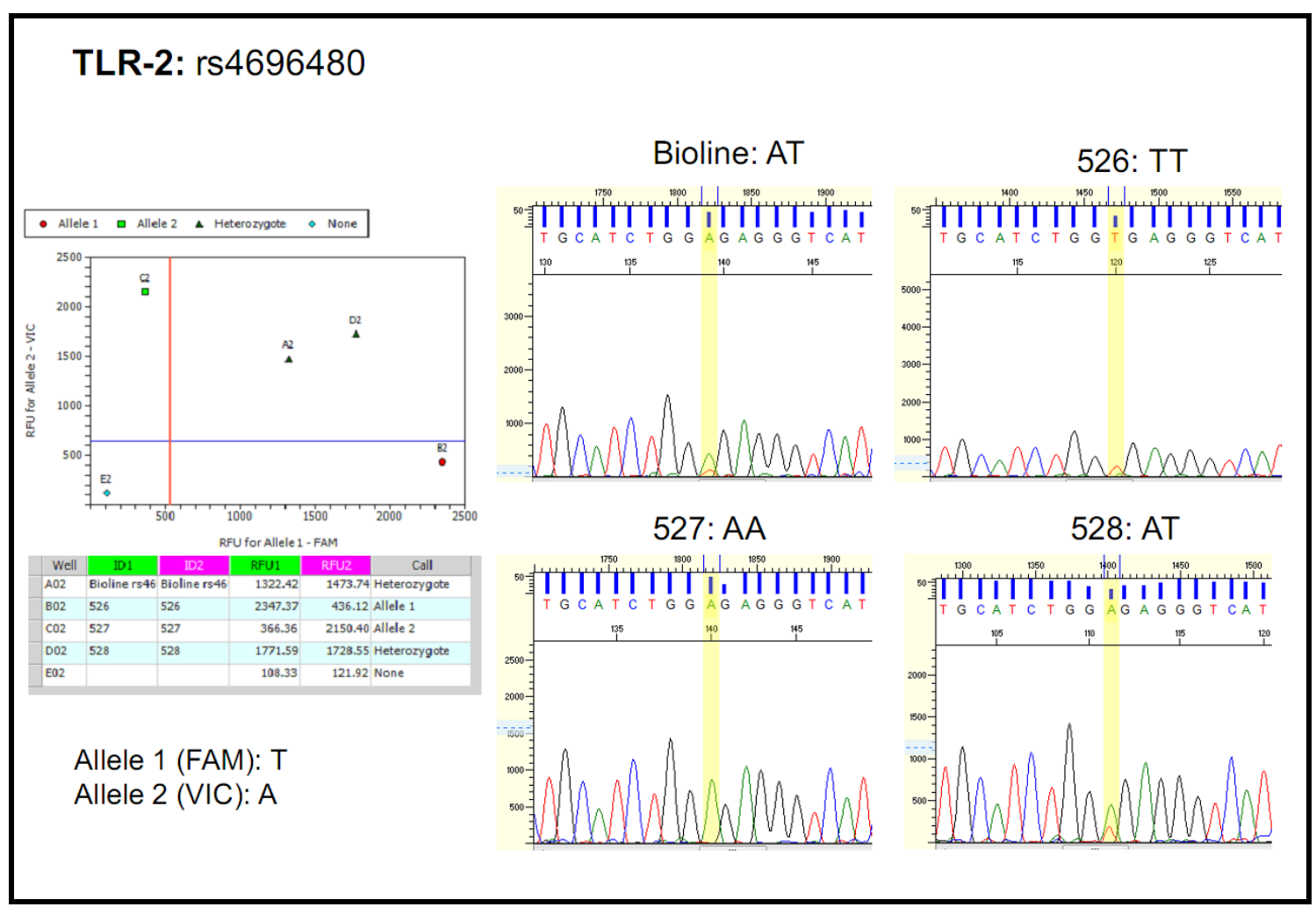

Figura A.3 - Resultados da comparação dos resultados de ensaio $\operatorname{TaqMan}^{\circledR}$ aos do sequenciamento com a validação do ensaio TaqMan ${ }^{\oplus}$ para o SNP TLR2-rs4696480

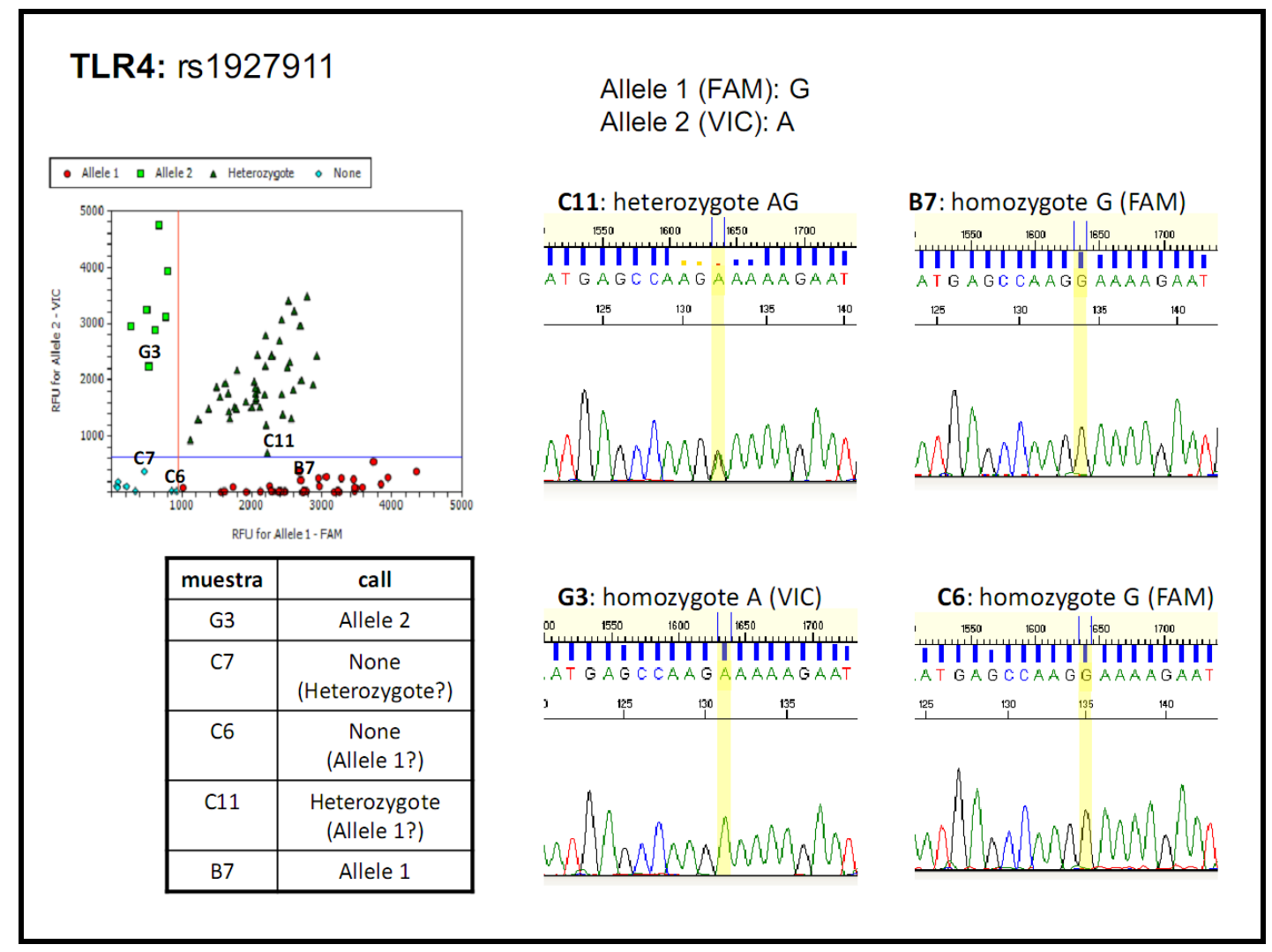

Figura A.4 - Resultados da comparação dos resultados de ensaio $\operatorname{TaqMan}^{\circledR}$ aos do sequenciamento com a validação do ensaio TaqMan ${ }^{\circledR}$ para o SNP TLR4-rs1927911 
TLR-6: rs5743810
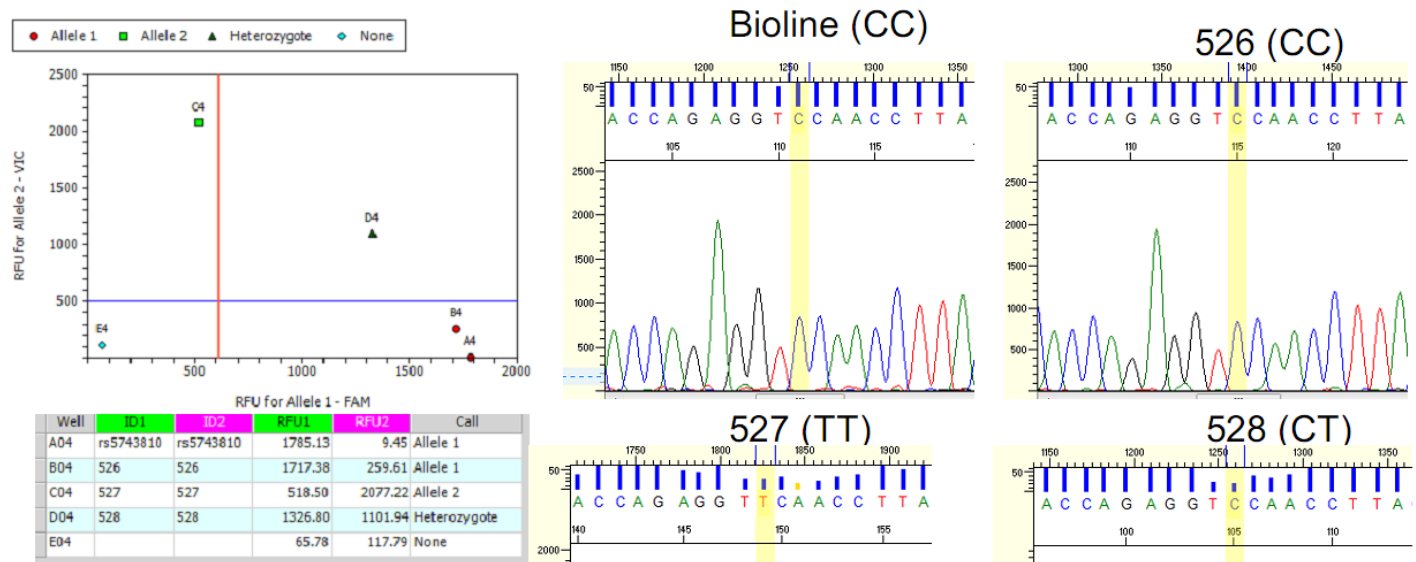

$528(\mathrm{CT})$

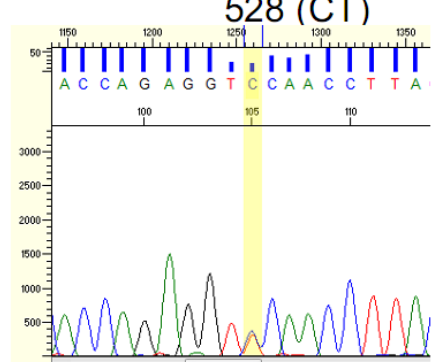

Allele 1 (FAM): C

Allele 2 (VIC): $\mathrm{T}$

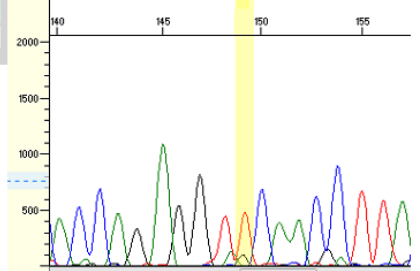

Figura A.5 - Resultados da comparação dos resultados de ensaio TaqMan ${ }^{\circledR}$ aos do sequenciamento com a validação do ensaio TaqMan ${ }^{\circledR}$ para o SNP TLR6-rs5743810

TLR-9: rs352139

527: Forward (GG)

527: Reverse (CC)
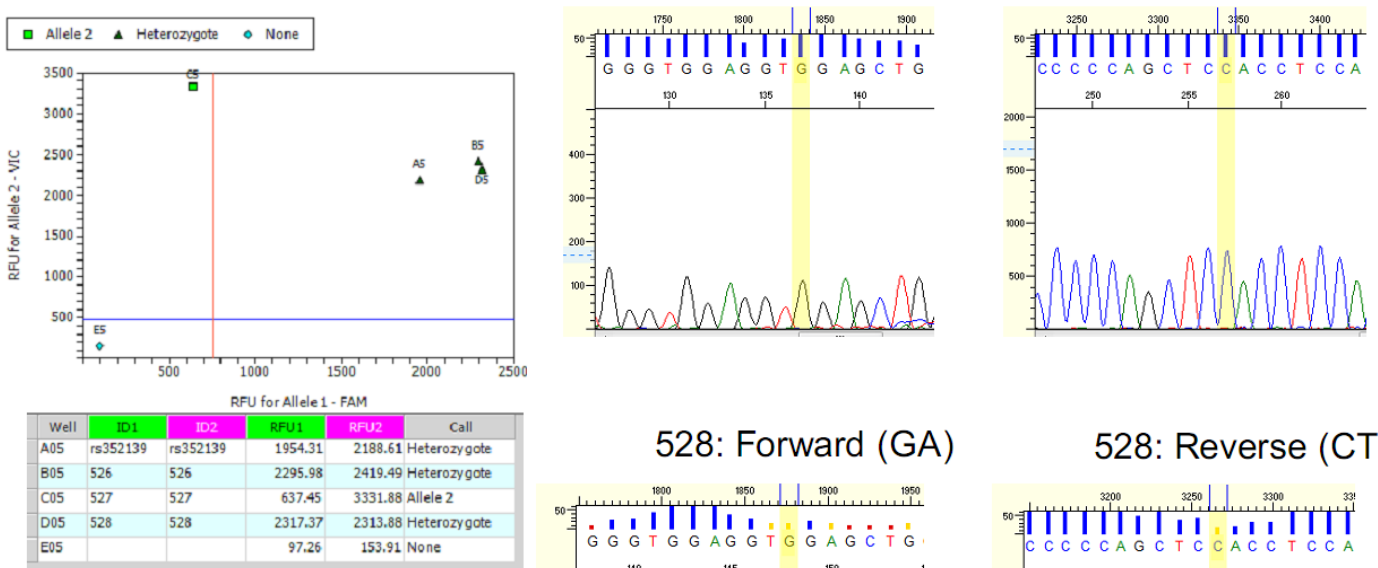

528: Forward (GA)

528: Reverse (CT)
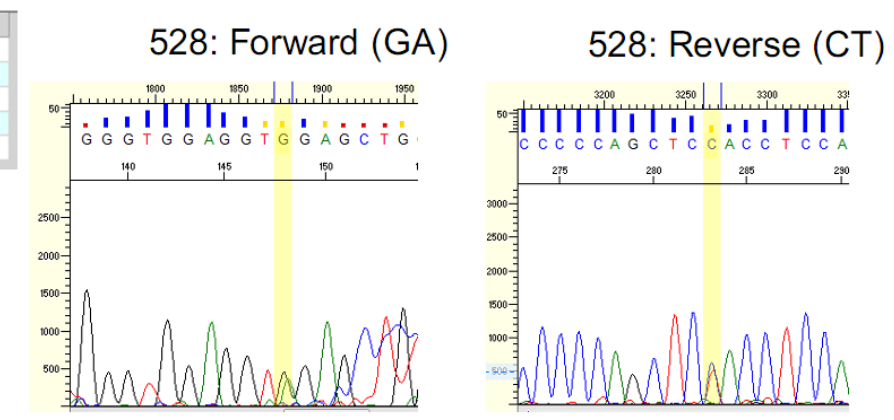

Allele 1 (FAM): C

Allele 2 (VIC): T

Figura A.6 - Resultados da comparação dos resultados de ensaio TaqMan ${ }^{\Theta}$ aos do sequenciamento com a validação do ensaio TaqMan ${ }^{\circledR}$ para o SNP TLR9-rs352139 
TLR-10: rs11096957

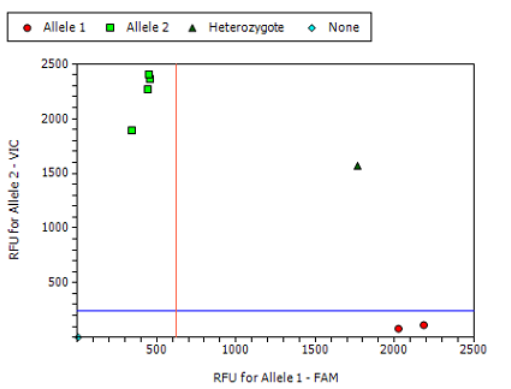

Bioline (AA)

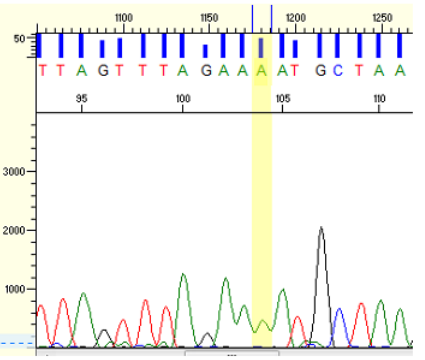

$523(\mathrm{AC})$
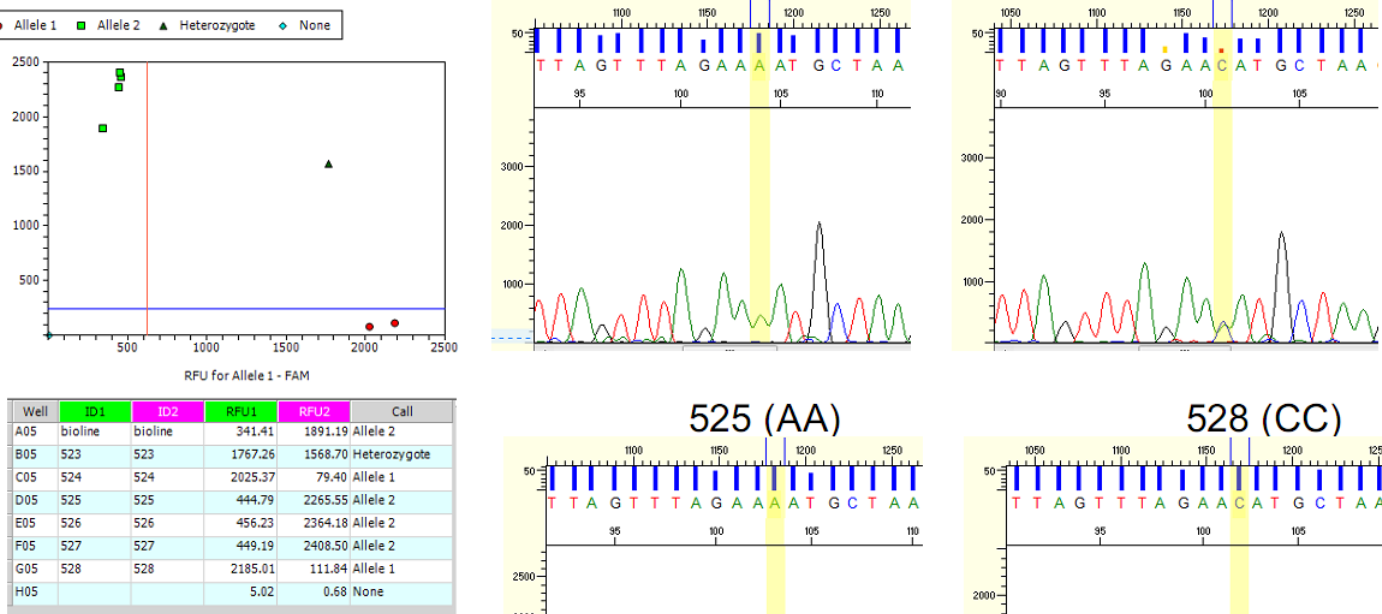

Allele 1 (FAM): C

Allele 2 (VIC): A

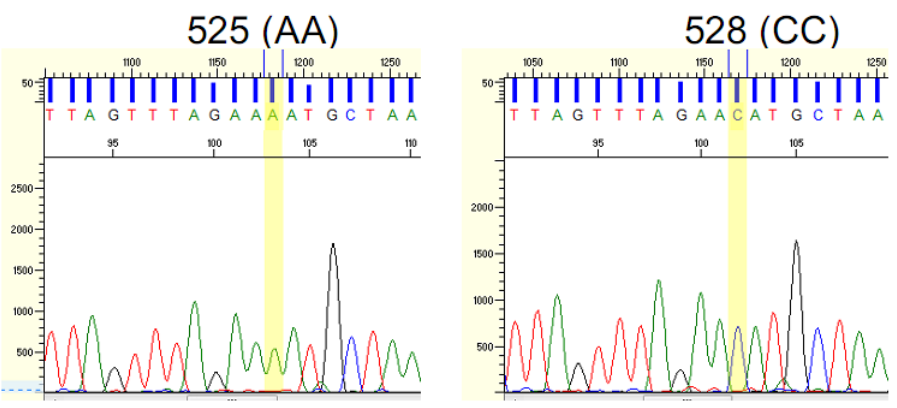

Figura A.7 - Resultados da comparação dos resultados de ensaio TaqMan ${ }^{\circledR}$ aos do sequenciamento com a validação do ensaio TaqMan $^{\circledR}$ para o SNP TLR10-rs110969579 
APÊNDICE B - Resultados das análises estatísticas para os SNP restantes que não apresentaram resultado estatisticamente significativo

Tabela B.1 - Análise dos resultados da genotipagem do SNP TLR1-rs4833095, frequência e odds ratio de cada genótipo e análise estatística, das diferentes doenças estudadas (LPO, CEC de Boca, CEC de laringe) em relação aos controles

\begin{tabular}{ccccc}
\hline & Controle & CEC de boca & CEC de laringe & LPO \\
\hline TT & 40 & 18 & 14 & 74 \\
$\%$ & 44.9 & 45 & 40 & 42.3 \\
OR $(95 \% \mathrm{Cl})$ & & 1 & 1 & 1 \\
\hline $\mathrm{CT}$ & 41 & 16 & 16 & 80 \\
$\%$ & 46.1 & 40 & 45.7 & 45.7 \\
OR $(95 \% \mathrm{Cl})$ & & $1,247(0,407-3,819)$ & $0,875(0,271-2,823)$ & $0,831(0,446-1,545)$ \\
\hline $\mathrm{CC}$ & 8 & 6 & 5 & 21 \\
$\%$ & 9 & 15 & 14.3 & 12 \\
OR $(95 \% \mathrm{Cl})$ & & $2,243(0,365-13,782)$ & $1,653(0,299-9,138)$ & $1,824(0,674-4,939)$ \\
\hline p-value & & 0.576 & 0.678 & 0.746 \\
\hline OR p-value & & 0.673 & 0.772 & 0.291 \\
\hline
\end{tabular}

Tabela B.2 - Análise dos resultados da genotipagem do SNP TLR1-rs5743618, frequência e odds ratio de cada genótipo e análise estatística, das diferentes doenças estudadas (LPO, CEC de Boca, CEC de laringe) em relação aos controles

\begin{tabular}{ccccc}
\hline & Controle & CEC de boca & CEC de laringe & LPO \\
\hline $\mathrm{AA}$ & 12 & 10 & 7 & 29 \\
$\%$ & 13.5 & 25 & 20 & 16.6 \\
OR $(95 \% \mathrm{Cl})$ & & 1 & 1 & 1 \\
\hline $\mathrm{AC}$ & 41 & 13 & 17 & 85 \\
$\%$ & 46.1 & 32.5 & 48.6 & 48.6 \\
OR $(95 \% \mathrm{Cl})$ & & $0,394(0,692-1,684)$ & $0,227(0,042-1,212)$ & $0,543(0,227-1,299)$ \\
\hline $\mathrm{CC}$ & 36 & 17 & 11 & 61 \\
$\%$ & 40.4 & 42.5 & 31.4 & 34.9 \\
OR $(95 \% \mathrm{Cl})$ & & $0,395(0,689-1,749)$ & $0,338(0,061-1,869)$ & $0,583(0,241-1,412)$ \\
\hline p-value & & 0.184 & 0.53 & 0.624 \\
\hline OR p-value & & 0.384 & 0.205 & 0.363 \\
\hline
\end{tabular}


Tabela B.3 - Análise dos resultados da genotipagem do SNP TLR6-rs5743810, frequência e odds ratio de cada genótipo e análise estatística, das diferentes doenças estudadas (LPO, CEC de Boca, CEC de laringe) em relação aos controles

\begin{tabular}{ccccc}
\hline & Controle & CEC de boca & CEC de laringe & LPO \\
\hline GG & 27 & 12 & 9 & 67 \\
$\%$ & 30.3 & 30 & 25.7 & 38.3 \\
OR (95\% Cl) & & 1 & 1 & 1 \\
\hline AG & 42 & 22 & 22 & 82 \\
$\%$ & 47.2 & 55 & 62.9 & 46.9 \\
OR (95\% Cl) & & $1,951(0,575-6,62)$ & $1,547(0,423-5,658)$ & $0,866(0,448-1,675)$ \\
\hline AA & 20 & 6 & 4 & 26 \\
$\%$ & 22.5 & 15 & 11.4 & 14.9 \\
OR (95\% Cl) & & $0,672(0,143-3,166)$ & $0,571(0,109-2,982)$ & $0,602(0,261-1,387)$ \\
\hline p-value & & 0.576 & 0.227 & 0.222 \\
\hline OR p-value & & 0.267 & 0.399 & 0.488 \\
\hline
\end{tabular}

Tabela B.4 - Análise dos resultados da genotipagem do SNP TLR9-rs5743836, frequência e odds ratio de cada genótipo e análise estatística, das diferentes doenças estudadas (LPO, CEC de Boca, CEC de laringe) em relação aos controles

\begin{tabular}{ccccc}
\hline & Controle & CEC de boca & CEC de laringe & LPO \\
\hline CT & 26 & 11 & 6 & 51 \\
$\%$ & 29.2 & 27.5 & 17.1 & 29.1 \\
OR $(95 \% \mathrm{Cl})$ & & 1 & 1 & 1 \\
\hline CC & 63 & 29 & 29 & 124 \\
$\%$ & 70.8 & 72.5 & 82.9 & 70.9 \\
OR $(95 \% \mathrm{Cl})$ & & $0,748(0,256-2,486)$ & $2,12(0,55-8,182)$ & $1,244(0,653-2,371)$ \\
\hline p-value & & 1 & 0.254 & 1 \\
\hline OR p-value & & 0.697 & 0.266 & 0.507 \\
\hline
\end{tabular}

Tabela B.5 - Análise dos resultados da genotipagem do SNP TLR10-rs11096957, frequência e odds ratio de cada genótipo e análise estatística, das diferentes doenças estudadas (LPO, CEC de Boca, CEC de laringe) em relação aos controles

\begin{tabular}{ccccc}
\hline & Controle & CEC de boca & CEC de laringe & LPO \\
\hline GG & 13 & 6 & 9 & 37 \\
$\%$ & 14.6 & 15 & 25.7 & 21.1 \\
OR (95\% Cl) & & 1 & 1 & 1 \\
\hline TG & 38 & 17 & 15 & 83 \\
$\%$ & 42.7 & 42.5 & 42.9 & 47.4 \\
OR (95\% Cl) & & $0,959(0,179-5,127)$ & $0,297(0,061-1,461)$ & $0,750(0,328-1,716)$ \\
\hline TT & 38 & 17 & 11 & 55 \\
$\%$ & 42.7 & 42.5 & 31.4 & 31.4 \\
OR (95\% Cl) & & $0,423(0,076-2,36)$ & $0,245(0,048-1,262)$ & $0,482(0,206-1,129)$ \\
\hline p-value & & 0.998 & 0.279 & 0.154 \\
\hline OR p-value & & 0.328 & 0.2 & 0.184 \\
\hline
\end{tabular}




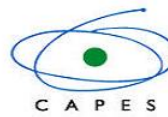

Coordenação de Aperfeiçoamento de Pessoal de Nivel Superior Setor Bancário Norte, Quadra 2, Bloco L, Lote 06 70040-020 - Brasilia, DF

C A P E S Brasil

A QUEM INTERESSAR POSSA

Declaramos, para os devidos fins, que o(a) interessado(a) abaixo, foi bolsista da Capes e realizou Estágio de doutorando no Exterior, por meio do Programa de Doutorado no País com Estágio no Exterior - PDEE.

BOLSISTA: CAMILA DE BARROS GALLO

PERÍODO DA BOLSA: 09/2011 a 02/2012

INSTITUIÇÃO: UNIVERSIDAD DEL PAIS VASCO

PAÍS: ESPANHA

ÁREA: ODONTOLOGIA.

Brasília, 29 de Maio de 2012

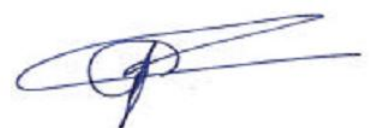

GERALDO NUNES SOBRINHO

Coordenador-Geral de Bolsas no Exterior

CAPES / DRI / CGBE / DAE - Divisão de Acompanhamento de Egressos do Exterior - $3^{\circ}$ andar -

E-mail: dae@capes.gov.br - Fone: 61-2022.6924 - Fax: 61-2022.6926

DOCUMENTO DE ENVIO DIGITAL 
ANEXO B - Parecer do Comitê de Ética em Pesquisa da FOUSP

Plataforma Brasil - Ministério da Saúde

Faculdade de Odontologia da Universidade de São Paulo

\title{
PROJETO DE PESQUISA
}

Título: Estudo de polimorfismos em genes de receptores Toll-Like em portadores de ulceração aftosa recorrente, líquen plano oral e câncer de boca

Área Temática:

\author{
Pesquisador: NORBERTO NOBUO SUGAYA \\ Instituição: Faculdade de Odontologia da Universidade de
}

Versão: 1 São Paulo

CAAE: 03771812.0 .0000 .0075

\section{PARECER CONSUBSTANCIADO DO CEP}

\author{
Número do Parecer: 47811 \\ Data da Relatoria: 29/06/2012
}

\section{Apresentação do Projeto:}

A ulceração aftosa recorrente (UAR) e o líquen plano oral (LPO) acometem a cavidade bucal causando dor e desconforto. Embora a etiopatogenia de ambas as condições ainda não estejam esclarecidas, vários fatores têm sido consistentemente relacionados ao desenvolvimento da UAR e do LPO, especialmente alterações imunológicas. O câncer bucal (CB) apresenta como principais fatores de risco para seu desenvolvimento o consumo crônico de tabaco e álcool, porém existem evidências de alterações imunológicas que contribuem para o crescimento e progressão do tumor, bem como da redução da efetividade da resposta imunológica antitumoral. Supõe-se que estas alterações imunológicas sejam determinadas geneticamente, em função da observação de herança de diversos genes que parecem conferir predisposição a UAR, ao LPO e ao CB. Os receptores Toll-Like (TLR), responsáveis pelo reconhecimento dos produtos moleculares derivados de diferentes classes de microrganismos, atuam na sinalização da resposta imunológica inata. Anormalidades envolvendo as funções destes podem proporcionar resposta imunológica aberrante em doenças crônicas inflamatórias e no câncer. Desta forma, pretende-se avaliar a presença de polimorfismos nos genes dos TLRs por meio de PCR em tempo real, por meio de ensaios TaqMan, em população portadora de UAR, LPO e CB em relação a indivíduos controles sadios.

\section{Objetivo da Pesquisa:}

Identificar a presença de polimorfismos nos genes dos receptores Toll-Like em população portadora de ulceração aftosa recorrente, líquen plano oral, câncer de boca e indivíduos controles sadios, buscando identificar diferenças entre esses grupos de pacientes em relação aos indivíduos controles sadios, buscando contribuir com o esclarecimento da etiopatogenia desta doença.

\section{Avaliação dos Riscos e Benefícios:}

Não há previsão de riscos para este estudo. O procedimento de coleta de células da boca será realizado por meio de bochecho com solução estéril supervisionada por profissional habilitado, dentista, sob condições adequadas de assepsia e segurança.

Não haverá benefício direto. O voluntário receberá toda informação e orientação em relação ao protocolo e objetivos da pesquisa e estará colaborando com a evolução do conhecimento científico nesta área e, desta forma, possibilitando a melhoria dos protocolos de tratamento para estas doenças.

\section{Comentários e Considerações sobre a Pesquisa:}

Inicialmente foi planejada a avaliação dos polimorfismos de receptores Toll-Like apenas em pacientes portadores de ulceração aftosa recorrente, para o qual já foi obtido o parecer favorável do CEP-FOUSP (parecer anexo aos documentos apresentados). No entanto, em virtude de indícios apontados em literatura, os pesquisadores sugerem a ampliação desta avaliação para duas outras condições que acometem a cavidade oral e que apresentam participação do processo inflamatório e imunológico envolvendo os receptores Toll-like, o líquen plano oral e o câncer bucal. Estes pacientes serão selecionados entre aqueles que buscam diagnóstico/tratamento ou se encontram em acompanhamento no ambulatório da Disciplina de Estomatologia Clínica, tal como foram e estão sendo incluídos os indivíduos portadores de ulceração aftosa recorrente e os individuos controle. $\mathrm{O}$ 


\section{Protocol: DNA Purification from Buccal Cells in Mouthwash Using the Gentra Puregene Buccal Cell Kit}

This protocol is for purification of genomic DNA from buccal cells in $10 \mathrm{ml}$ mouthwash using the Gentra Puregene Buccal Cell Kit.

Things to do before starting

Preheat water bath to $65^{\circ} \mathrm{C}$ for use in step 22 of the procedure.

Procedure

1. Dispense $10 \mathrm{ml}$ Original Mint Scope ${ }^{\circledast}$ Mouthwash (Procter \& Gamble) or Listerine ${ }^{\circledast}$ mouthwash (McNEIL-PPC, Inc) into a $50 \mathrm{ml}$ centrifuge tube.

2. Collect buccal cells by rinsing the mouth with mouthwash and then spit the mouthwash into a $50 \mathrm{ml}$ tube.

For best results, wait at least $1 \mathrm{~h}$ after eating or drinking to collect buccal cells.

Samples may be stored at room temperature $\left(15-25^{\circ} \mathrm{C}\right)$ for up to 7 days.

3. Centrifuge for $\mathbf{5} \mathrm{min}$ at $2000 \times \mathrm{g}$ to pellet cells.

If the cell pellet is too loose, repeat the centrifugation.

4. Carefully discard the supernatant by pipetting or pouring, leaving the pellet undisturbed.

5. Add $1 \mathrm{ml}$ Cell Lysis Solution, and mix by inverting $\mathbf{5 0}$ times.

6. Incubate for $\mathbf{1 5} \mathrm{min}$ at room temperature.

7. Add $10 \mu$ l Puregene Proteinase K (cat. no. 158918), and mix by inverting 3 times.

8. Vortex vigorously at high speed for $20 \mathrm{~s}$ to mix.

9. Incubate for $10 \mathrm{~min}$ at room temperature.

10. Add $340 \mu$ Protein Precipitation Solution, and vortex vigorously for $20 \mathrm{~s}$ at high speed.

11. Incubate for $10 \mathrm{~min}$ on ice.

Incubation on ice is important to ensure a tight pellet in the next step.

12. Centrifuge for $10 \mathrm{~min}$ at $2000 \times \mathrm{g}$.

The precipitated proteins should form a tight, green pellet. If the protein pellet is not tight, incubate on ice for $5 \mathrm{~min}$ and repeat the centrifugation.

13. Pipet $1 \mathrm{ml}$ isopropanol and $2 \mu \mathrm{l} \mathrm{Glycogen} \mathrm{Solution} \mathrm{into} \mathrm{a} \mathrm{clean} 15$ or $50 \mathrm{ml}$ centrifuge tube 
14. Pour the supernatant containing the DNA (leaving behind the precipitated protein pellet) into the tube containing isopropanol and Glycogen Solution. Keep samples on ice while transferring supernatant to ensure pellet remains tight.

Be sure the protein pellet is not dislodged during pouring.

Keeping the samples on ice is important to ensure a tight pellet.

15. Mix by inverting gently 50 times.

16. Centrifuge for $5 \mathrm{~min}$ at $2000 \mathrm{xg}$.

17. Carefully discard the supernatant, and drain the tube by inverting on a clean piece of absorbent paper, taking care that the pellet remains in the tube.

18. Add $1 \mathrm{ml}$ of $70 \%$ ethanol and invert several times to wash the DNA pellet.

19. Centrifuge for $1 \mathrm{~min}$ at $2000 \mathrm{xg}$.

20. Carefully discard the supernatant. Drain the tube on a clean piece of absorbent paper, taking care that the pellet remains in the tube. Allow to air dry for 5-10 min. The pellet might be loose and easily dislodged. Avoid over-drying the DNA pellet, as the DNA will be difficult to dissolve.

21. Add $400 \mathrm{pl}$ DNA Hydration Solution and vortex for $5 \mathrm{~s}$ at medium speed to mix.

22. Incubate at $65^{\circ} \mathrm{C}$ for $1 \mathrm{~h}$ to dissolve the DNA.

23. Incubate at room temperature overnight with gentle shaking. Ensure tube cap is tightly closed to avoid leakage. Samples can then be centrifuged briefly and transferred to a storage tube. 
ANEXO D - Metodologia de separação, sustentação e limpeza da fita-simples de DNA molde previa ao pirosequenciamento (QIAGEN® - Duesseldorf, Alemanha)

\section{Technicallnformation}

\section{PyroMark $^{\circledR}$ Q96 Vacuum Workstation quick-start guide}

This Technical Information summarizes the immobilization and preparation of PCR products for Pyrosequencing ${ }^{\circledR}$ using the PyroMark Q96 Vacuum Workstation. Before beginning, carefully read Section 5.3.3 of the PyroMark Q96 ID User Manual or Section 5.3.5 of the PyroMark Q96 MD User Manual and pay particular attention to the safety information.

\section{Immobilizing the $\mathrm{PCR}$ products}

1. Make a master mix according to the flowchart to the right. Note: Before pipetting, gently shake the bottle of streptavidin-coated Sepharose ${ }^{\circledast}$ beads* to ensure a homogenous suspension.

2. Depending on sample volume and instrument type, pipet the correct amount of master mix into each necessary well of a PCR plate to give a total volume of $80 \mu \mathrm{l}$ per well.

3. Add PCR product to each well, according to instrument type.

4. Seal the wells with strip caps and agitate the PCR plate at $1400 \mathrm{rpm}$ for 5-10 min at room temperature $\left(15-25^{\circ} \mathrm{C}\right)$ using an orbital shaker.

\section{Separation of DNA strands and release of samples} into the PyroMark plate

1. Dilute sequencing primers with PyroMark Annealing Buffer (cat. no. 979009) and pipet into each necessary well of the instrument-specific PyroMark plate. Position the plate on the workstation.

ID: $40 \mu$ sequencing primer at $0.4 \mu \mathrm{M}$ in the PyroMark Q96 Plate Low MD: $12 \mu$ sequencing primers at $0.3 \mu \mathrm{M}$ in the PyroMark Q96 HS Plate

2. Fill the workstation troughs according to the diagram to the right.

3. Start the pump and apply vacuum to the tool by opening the switch.

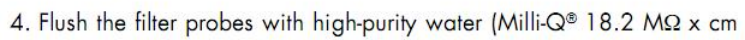
or equivalent) in the "Parking" trough (P). Refill the trough with fresh high-purity water for use in step 12 .

5. Position the PCR plate on the workstation. Ensure that both plates are in the same orientation as when the samples were loaded.

"Streptovidin Sepharose High Performance ( $34 \mu \mathrm{m}, 5 \mathrm{ml}$, GE Healthcare). This is not o complete list of suppliers and does not include many important vendors of biological supplies.

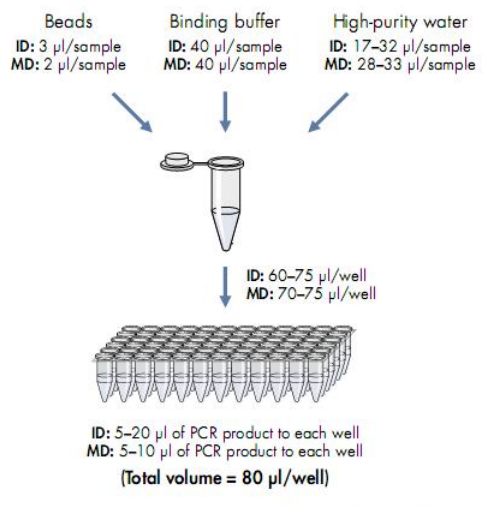

Preparing the master mix to immobilize the PCR product.
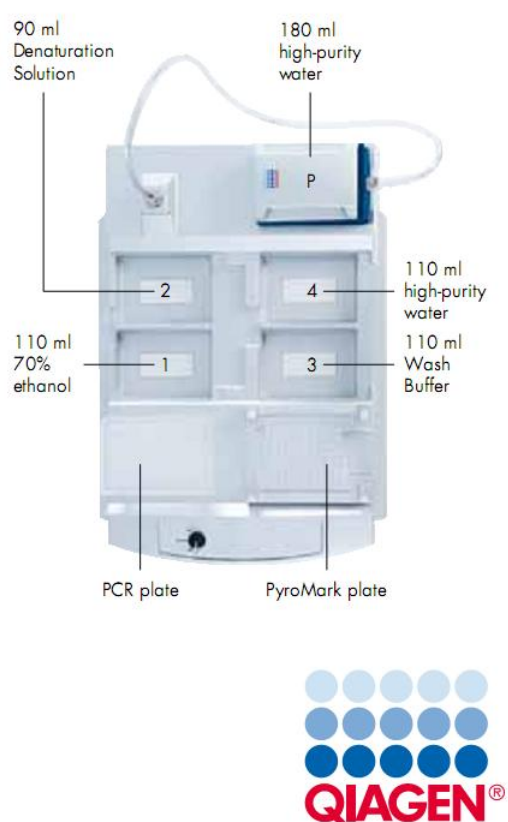
6. With the vacuum switch $O N$, lower the vacuum tool into the wells of the PCR plate for $15 \mathrm{~s}$ to capture the beads with PCR product.

7. With vacuum $\mathrm{ON}$, flush the tool with $70 \%$ ethanol (trough 1) for $5 \mathrm{~s}$

8. With vacuum $\mathrm{ON}$, flush the tool with Denaturation Solution (trough 2) for $5 \mathrm{~s}$.

8. With vacuum $\mathrm{ON}$, flush the tool with Wash Buffer (trough 3) for $10 \mathrm{~s}$.

10. With vacuum $\mathrm{ON}$, raise the tool to beyond $90^{\circ}$ vertical for $5 \mathrm{~s}$.

11. Align the vacuum tool with the PyroMark plate and switch the vacuum OFF. Lower the vacuum tool into the wells and gently shake from side to side to release the beads.

12. With the vacuum OFF, agitate the vacuum tool in high-purity water (trough 4) for $10 \mathrm{~s}$.

13. With vacuum $O N$, flush the filter probes with high-purity water (trough P) for $5 \mathrm{~s}$.

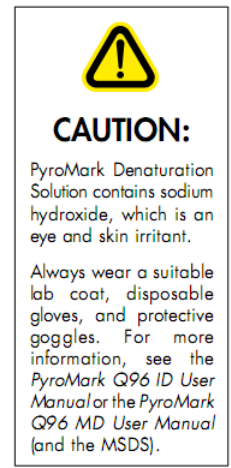

14. Raise the vacuum tool to beyond $90^{\circ}$ vertical for $5 \mathrm{~s}$, then switch the vacuum OFF and store the tool in the "Parking" position.

\section{Annealing sequencing primers to DNA strands}

Place the PyroMark Q96 Plate Low in a prewarmed PyroMark Q96 Sample Prep Thermoplate Low. Alternatively, place the PyroMark Q96 HS Plate in a prewarmed PyroMark Q96 HS Sample Prep Thermoplate. Heat the Pyrosequencing samples on a heating block at $80^{\circ} \mathrm{C}$ for 2 minutes. Remove the plate from the thermoplate and allow the samples to cool to room temperature $\left(15-25^{\circ} \mathrm{C}\right)$ for at least 5 minutes. The cooled plate can now be processed.

\section{Cleaning the vacuum workstation}

Liquid waste and solutions remaining in the troughs of the vacuum workstation should be appropriately discarded at the end of the day. For details, see your instrument user manual.

For up-to-date licensing information and product-specific disclaimers, see the PyroMark Q96 ID User Manual or PyroMark Q96 MD User Manual. The PyroMark Q96 ID User Manual and PyroMark Q96 MD User Manual are available at www.qiagen.com or can be requested from QIAGEN Technical Services or your local distributor.

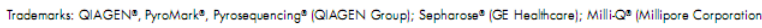

1065958 12/2010 O 2010 Q/AGEN, all rights reserved.

Australia $=1.800-243.800$ Austria $=0800.281011$ Belgium $=0800.79612$ Brazil = 0800-557779 Canada $=800-572.9613$ China $=800.988 .0325$ Denmark $=80.885945$
Japan $=03.6890 .7300$ Korea (South) $=080.000 .7145$ Luxembourg = 80022076 Mexico = 01-800-77 42-43 The Netherlands $=0800-0229592$ Norway $=800.18859$ Singapore $=1800-742-4368$

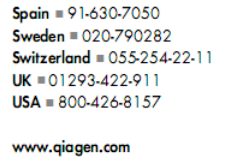

www.qiagen.com

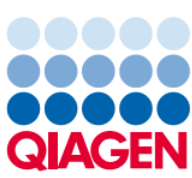

